UNIVERSIDADE DE SÃO PAULO

ESCOLA DE ENGENHARIA DE SÃO CARLOS

DEPARTAMENTO DE GEOTECNIA

\title{
AVALIAÇÃO DA CONDUTIVIDADE HIDRÁULICA E DA RESISTÊNCIA AO CISALHAMENTO DE MISTURAS SOLO- BENTONITA: ESTUDO DE CASO DE UM ATERRO SANITÁRIO LOCALIZADO EM RIO GRANDE (RS)
}

\section{KARINA RETZLAFF CAMARGO}

Dissertação apresentada à Escola de Engenharia de São Carlos da Universidade de São Paulo, como parte dos requisitos para obtenção do título de Mestre em Geotecnia (Versão Corrigida).

ORIENTADOR: PROF. DR. EDMUNDO ROGÉRIO ESQUIVEL

$$
\begin{gathered}
\text { SÃO CARLOS - SP } \\
2012
\end{gathered}
$$


AUTORIZO A REPRODUÇÃO TOTAL OU PARCIAL DESTE TRABALHO, POR QUALQUER MEIO CONVENCIONAL OU ELETRONNICO, PARA FINS DE ESTUDO E PESQUISA, DESDE QUE CITADA A FONTE.

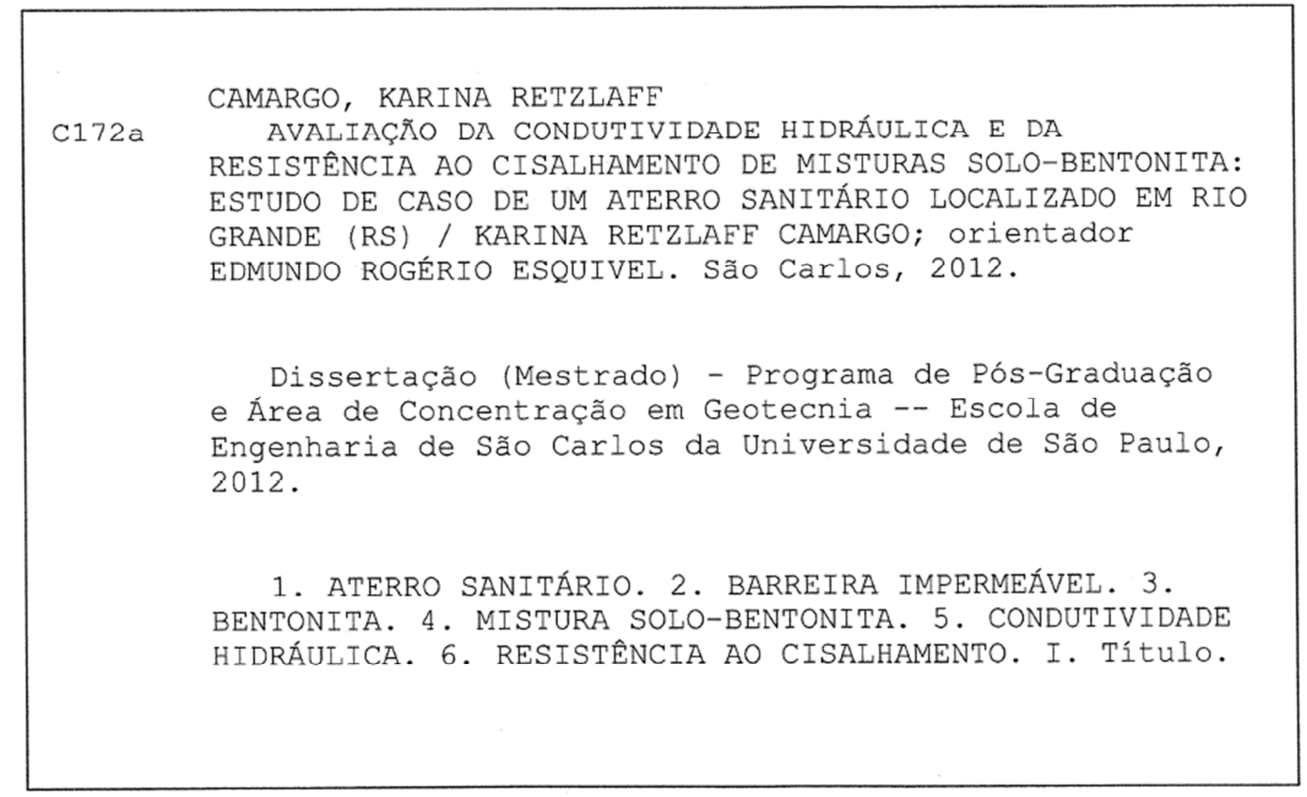




\section{FOLHA DE JULGAMENTO}

Candidata: Engenheira KARINA RETZLAFF CAMARGO.

Título da dissertação: "Avaliação da condutividade hidráulica e da resistência ao cisalhamento de misturas solobentonita: estudo de caso de um aterro sanitário localizado em Rio Grande (RS)".

Data da defesa: 15/10/2012

Comissão Julgadora:

Prof. Dr. Edmundo Rogério Esquivel (Orientador)

(Escola de Engenharia de São Carlos/EESC)

Prof. Dr. Cezar Augusto Burkert Bastos

(Universidade Federal do Rio Grande/FURG)

Prof?. Titular Maria Eugenia Gimenez Boscov

(Escola Politécnica/USP)
Resultado:

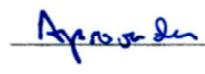

froxpd

Ciprovada

Coordenador do Programa de Pós-Graduação em Geotecnia:

Prof. Titular Osni José Pejon

Presidente da Comissão de Pós-Graduação:

Prof. Titular Denis Vinicius Coury 

À minha mãe, Elma Retzlaff Camargo, pelo seu amor incondicional. E à memória de meu amado pai, Vanderlete Camargo. 



\section{Agradecimentos}

Ao Professor e Orientador Edmundo Rogério Esquivel pela atenção, orientação, incentivo e amizade ao longo desta pesquisa.

Ao Dr. Cezar Augusto Burkert Bastos pela prontidão em ajudar sempre que necessário e pelo incentivo em todos os momentos.

À Dra. Juliana Azoia Lukiantchuki pelo brilhante trabalho que serviu de base para que esta pesquisa pudesse ser desenvolvida e por toda ajuda concedida nas mais diversas fases de realização da pesquisa.

Ao Eng. Christopher Fonseca da Silva pelo companheirismo demonstrado ao longo de todos esses anos.

À M.Sc. Giovana Georgetti Bizão por toda a ajuda durante a fase experimental da pesquisa.

Aos professores e funcionários do Departamento de Geotecnia por todo o apoio ao longo desta pesquisa.

À Coordenação de Aperfeiçoamento de Pessoal de Nível Superior (CAPES) pelo suporte financeiro. 

Camargo, K. R. Avaliação da condutividade hidráulica e da resistência ao cisalhamento de misturas solo-bentonita: estudo de caso de um aterro sanitário localizado em Rio Grande (RS). 2012. 103 p. Dissertação de Mestrado - Escola de Engenharia de São Carlos, Universidade de São Paulo, São Carlos, 2012.

A utilização do solo natural compactado com bentonita empregado em camadas impermeáveis para retenção de contaminantes é bastante usual para aterros sanitários. Neste trabalho são apresentados resultados de ensaios condutividade hidráulica e de resistência ao cisalhamento, realizados em equipamentos triaxiais. Além do solo natural, foram utilizadas misturas solo-bentonita nos teores de $2 \%, 4 \%$ e $6 \%$. O solo arenoso ensaiado é encontrado na Planície Costeira Sul do Estado do Rio Grande do Sul. Os valores de condutividade hidráulica diminuíram tanto com o acréscimo do teor de bentonita, quanto com o aumento da tensão de confinamento. A condutividade hidráulica do solo apresentou uma redução de três ordens de grandeza quando este foi compactado com $6 \%$

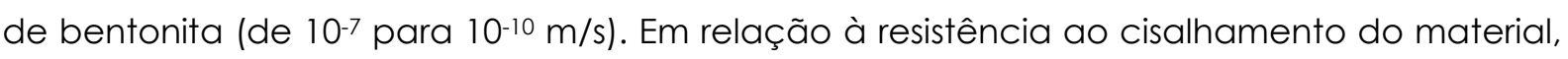
constatou-se que com o acréscimo do teor bentonita de 0 para $6 \%$, a coesão efetiva aumentou (de 2,3 para 12,8 kPa) e o ângulo de atrito efetivo diminuiu (de $22,7^{\circ}$ pra $14,0^{\circ}$ ) .

PALAVRAS-CHAVE: Aterro sanitário, barreira impermeável, bentonita, mistura solobentonita, condutividade hidráulica, resistência ao cisalhamento. 

Camargo, K. R. Evaluation of hydraulic conductivity and shear strength of soilbentonite mixtures: a case study of a landfill located in Rio Grande (RS). 2012. 103 p. Master Thesis, School of Engineering at São Carlos, University of São Paulo, São Carlos, 2012.

Compacted soil-bentonite mixtures used as impermeable layers for retention of contaminants is quite usual in landfills. This paper presents the results of hydraulic conductivity and shear strength tests conducted in a triaxial apparatus. Natural soil, and soil-bentonite mixtures at $2 \%, 4 \%$ and $6 \%$ concentrations were tested. The sandy soil tested is found in the Southern Coastal Plain of Rio Grande do Sul. The hydraulic conductivity decreased with both the increase of bentonite content and increase of confining stress. Compared to natural soil, the hydraulic conductivity of compacted soil-bentonite mixtures at $6 \%$ content decreased by three orders of magnitude (from $10^{-7}$ to $10^{-10} \mathrm{~m} / \mathrm{s}$ ). Regarding the material shear strength, it was found that when the natural soil is compared to compacted soil-bentonite mixtures at $6 \%$ content, the effective cohesion increased (from 2.3 to $12.8 \mathrm{kPa}$ ) and the effective friction angle decreased (from $22.7^{\circ}$ to $14.0^{\circ}$ ).

KEYWORDS: Landfill, low-permeability liner, bentonite, soil-bentonite mixture, hydraulic conductivity, shear strength. 



\section{Lista de figuras}

Figura 2.1: Localização do município de Rio Grande/RS .05

Figura 3.1: Estrutura de um aterro sanitário (ENGECORPS, 1996).

Figura 3.2: Desenho esquemático de um aterro sanitário (adaptado de DANIEL, 1998)...... 13

Figura 3.3: Corte da secção de um aterro sanitário (MANUAL DE OPERAÇÕES DE ATERROS SANITÁRIOS, 2002)

Figura 3.4: Estrutura cristalina da montmorilonita (adaptado de MITCHELL, 1993)...... 18

Figura 3.5: Variação da condutividade hidráulica com o teor de bentonita (adaptado de DANIEL, 1993).

Figura 3.6: Método tradicional para a especificação da zona seca admissível mediante teor de umidade e peso específico seco de solos argilosos (adaptado de DANIEL \& BENSON, 1999)

Figura 3.7: Recomendações de projeto (adaptado de BENSON \& DANIEL, 1990)......

Figura 3.8: Área aceitável baseado na condutividade hidráulica, contração volumétrica e resistência ao cisalhamento (adaptado de DANIEL \& WU, 1993).....

Figura 3.9: Diagrama do equipamento triaxial (adaptado de DAS, 2007).........

Figura 4.1: Ocorrência do solo estudado no litoral do Estado de Rio Grande do Sul e localização da jazida da qual o solo foi obtido (BASTOS et al, 1998)......

Figura 4.2: Perfil esquemático (W-E) transversal aos sistemas deposicionais da Planície Costeira Sul do Estado do Rio Grande do Sul (modificado de TOMAZELLI \& VILLWOCK, 2005)

Figura 4.3: Caixa de madeirite na qual foi transportada a amostra.

Figura 4.4: Sistema de aquisição de dados HBM, modelo MX410

Figura 4.5: Controle de qualidade da membrana.

Figura 4.6: Saturação das torneiras do pedestal da câmara triaxial.

Figura 4.7: Colocação do corpo de prova no pedestal da câmara triaxial..

Figura 4.8: Colocação das membranas protetoras. 
Figura 4.9: Corpo de prova protegido por membrana látex, fixada com anéis o'ring na base

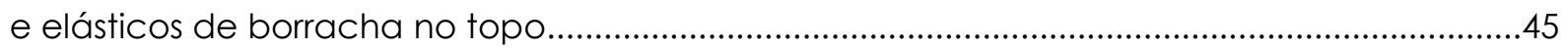

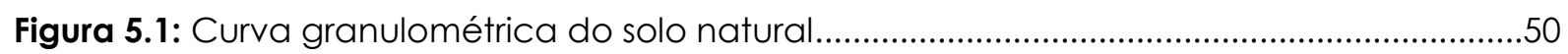

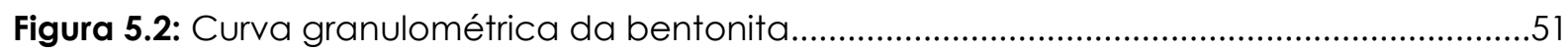

Figura 5.3: Curva granulométrica da mistura com $2 \%$ de bentonita..........................................51

Figura 5.4: Curva granulométrica da mistura com $4 \%$ de bentonita..........................................52

Figura 5.5: Curva granulométrica da mistura com $6 \%$ de bentonita............................................52

Figura 5.6: Curvas de compactação para o solo natural e para as misturas solo-

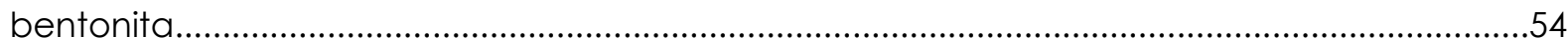

Figura 5.7: Condutividade hidráulica do solo natural................................................................56

Figura 5.8: Condutividade hidráulica da mistura com $2 \%$ de bentonita....................................56

Figura 5.9: Condutividade hidráulica da mistura com $4 \%$ de bentonita....................................57

Figura 5.10: Condutividade hidráulica da mistura com $6 \%$ de bentonita...................................57

Figura 5.11: Variação da condutividade hidráulica média em função do teor de

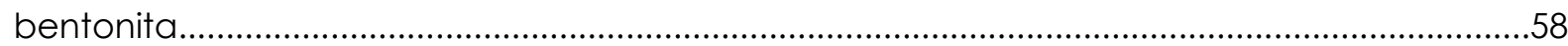

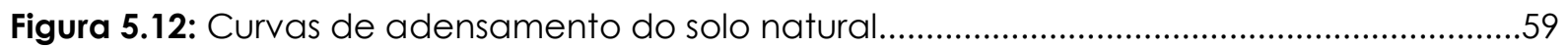

Figura 5.13: Curvas de adensamento da mistura com $2 \%$ de bentonita...................................59

Figura 5.14: Curvas de adensamento da mistura com $4 \%$ de bentonita.....................................60

Figura 5.15: Curvas de adensamento da mistura com $6 \%$ de bentonita....................................60

Figura 5.16: Condutividade hidráulica do solo natural após a fase de adensamento.............62

Figura 5.17: Condutividade hidráulica da mistura com $2 \%$ de bentonita após a fase de adensamento .63

Figura 5.18: Condutividade hidráulica da mistura com $4 \%$ de bentonita após a fase de adensamento.

Figura 5.19: Condutividade hidráulica da mistura com $6 \%$ de bentonita após a fase de adensamento .64

Figura 5.20: Condutividade hidráulica em função da tensão de confinamento e teor de bentonita. 
Figura 5.21: Curvas da tensão desviatória e pressão neutra versus deformação axial para o solo natural.

Figura 5.22: Curvas da tensão desviatória e pressão neutra versus deformação axial para a mistura com $2 \%$ de bentonita.

Figura 5.23: Curvas da tensão desviatória e pressão neutra versus deformação axial para a mistura com $4 \%$ de bentonita

Figura 5.24: Curvas da tensão desviatória e pressão neutra versus deformação axial para a mistura com $6 \%$ de bentonita.

Figura 5.25: Envoltória de resistência em termos de tensões totais do solo natural.

Figura 5.26: Envoltória de resistência em termos de tensões efetivas do solo natural.

Figura 5.27: Envoltória de resistência em termos de tensões totais da mistura com $2 \%$ de

bentonita

Figura 5.28: Envoltória de resistência em termos de tensões efetivas da mistura com $2 \%$ de bentonita

Figura 5.29: Envoltória de resistência em termos de tensões totais da mistura com $4 \%$ de bentonita

Figura 5.30: Envoltória de resistência em termos de tensões efetivas da mistura com $4 \%$ de bentonita.

Figura 5.31: Envoltória de resistência em termos de tensões totais da mistura com $6 \%$ de bentonita.

Figura 5.32: Envoltória de resistência em termos de tensões efetivas da mistura com $6 \%$ de bentonita

Figura 5.33: Tensão de desvio na ruptura em função do teor de bentonita.

Figura 5.34: Variação da coesão efetiva e ângulo de atrito efetivo em função do teor de bentonita 



\section{Lista de tabelas}

Tabela 3.1: Valores típicos de condutividade hidráulica (PINTO, 2000).....

Tabela 3.2: Classificação dos solos baseado nas condutividade hidráulicas (MITCHELL, 1993)

Tabela 4.1: Composição química da bentonita Permagel (Fonte: catálogo do fabricante)

Tabela 4.2: Propriedades da bentonita Permagel (Fonte: catálogo do fabricante) .38

Tabela 5.1: Resultados dos ensaios de caracterização geotécnica. .49

Tabela 5.2: Resultados dos ensaios de granulometria conjunta. 53

Tabela 5.3: Parâmetros de compactação correspondentes ao Ensaio do Proctor Intermediário .53

Tabela 5.4 Características de moldagem dos corpos de prova. 55

Tabela 5.5: Condutividade hidráulica $(\mathrm{m} / \mathrm{s})$ do solo natural e das misturas solo-bentonita antes da fase de adensamento. .57

Tabela 5.6: Deformação volumétrica de estabilização. .61

Tabela 5.7: Variação do índice de vazios com o teor de bentonita e a tensão confinante.

Tabela 5.8: Condutividade hidráulica $(\mathrm{m} / \mathrm{s})$ do solo natural e das misturas solo-bentonita para diferentes tensões de confinamento. .64

Tabela 5.9: Índice de condutividade hidráulica das amostras estudadas. 65

Tabela 5.10: Comparação entre os requisitos da CETESB (1993) e os parâmetros do solo natural e das misturas solo-bentonita. 73 



\section{Lista de abreviaturas e siglas}

$\begin{array}{ll}\text { SIGLA } & \text { - DESCRIÇÃO } \\ \text { ABNT } & \text { - Associação Brasileira de Normas Técnicas } \\ \text { ASTM } & \text { - American Society for Testing and Materials } \\ \text { CBR } & \text { - California Bearing Ratio } \\ \text { CETESB } & \text { - Companhia de Tecnologia de Saneamento Ambiental } \\ \text { DNER } & \text { - Departamento Nacional de Estradas de Rodagem } \\ \text { EESC } & \text { - Escola de Engenharia de São Carlos } \\ \text { EMBRAPA } & \text { - Empresa Brasileira de Pesquisa Agropecuária } \\ \text { ENGECORPS } & - \text { Corpo de Engenheiros Consultores } \\ \text { EPA } & - \text { Environmental Protection Agency } \\ \text { FURG } & - \text { Universidade Federal do Rio Grande } \\ \text { GCL } & - \text { Geosynthetic Clay Liner } \\ \text { IBGE } & - \text { Instituto Brasileiro de Geografia e Estatística } \\ \text { PNRS } & - \text { Política Nacional de Resíduos Sólidos } \\ \text { PNSB } & - \text { Pesquisa Nacional de Saneamento Básico } \\ \text { RSU } & - \text { Resíduos Sólidos Urbanos } \\ \text { USP } & - \text { Universidade de São Paulo }\end{array}$





\section{Lista de símbolos}

\begin{tabular}{|c|c|}
\hline SÍMBOLO & DESCRIÇÃO \\
\hline$\Delta h$ & - perda de carga do fluído percolante \\
\hline$\Delta \sigma$ & - tensão desviatória \\
\hline$\Delta \sigma$ máx & - tensão desviatória máxima \\
\hline$\Delta F$ & - variação da força \\
\hline$\varepsilon$ & - deformação axial \\
\hline$\varepsilon_{\vee}$ & - deformação volumétrica \\
\hline$\phi$ & - ângulo de atrito do solo \\
\hline$\phi$ & - ângulo de atrito efetivo do solo \\
\hline$\gamma$ & - peso específico \\
\hline$\gamma_{s}$ & - peso específico dos grãos \\
\hline Ya máx & - peso específico seco máximo \\
\hline$\sigma_{1}$ & - tensão vertical axial \\
\hline$\sigma_{3}$ & - tensão de confinamento \\
\hline$\mu$ & - viscosidade do líquido percolante \\
\hline$A_{c}$ & - área corrigida \\
\hline$A_{0}$ & - área inicial do corpo de prova \\
\hline$B$ & - parâmetro B de Skempton \\
\hline CP01 & - corpo de prova 01 \\
\hline CP02 & - corpo de prova 02 \\
\hline CP03 & - corpo de prova 03 \\
\hline$D_{0 \text { méd }}$ & - diâmetro inicial médio do corpo de prova \\
\hline$e$ & - índice de vazios \\
\hline$G C$ & - grau de compactação \\
\hline$h_{\text {o méd }}$ & - altura inicial média do corpo de prova \\
\hline$i$ & - gradiente hidráulico \\
\hline
\end{tabular}




\begin{tabular}{|c|c|}
\hline$I_{P}$ & - índice de plasticidade \\
\hline IA Skempton & - índice de atividade coloidal \\
\hline K & - permeabilidade intrínseca do solo \\
\hline$k$ & - condutividade hidráulica \\
\hline$l$ & - comprimento do corpo de prova \\
\hline$m$ & - massa \\
\hline$p$ & - coordenada do ponto na trajetória de tensão total \\
\hline$p^{\prime}$ & - coordenada do ponto na trajetória de tensão efetiva \\
\hline$p H$ & - potencial hidrogeniônico \\
\hline$q$ & - coordenada do ponto na trajetória de tensão total \\
\hline$q^{\prime}$ & - coordenada do ponto na trajetória de tensão efetiva \\
\hline$S r$ & - grau de saturação \\
\hline SOO & - solo natural \\
\hline SO2 & - mistura com $2 \%$ de bentonita \\
\hline SO4 & - mistura com $4 \%$ de bentonita \\
\hline S06 & - mistura com $6 \%$ de bentonita \\
\hline$t$ & - tempo \\
\hline$v$ & - velocidade de percolação \\
\hline$V_{0}$ & - volume inicial do corpo de prova \\
\hline$w$ & - teor de umidade \\
\hline$w_{L}$ & - limite de liquidez \\
\hline$w_{o t}$ & - teor de umidade ótimo \\
\hline$w_{P}$ & - limite de plasticidade \\
\hline
\end{tabular}




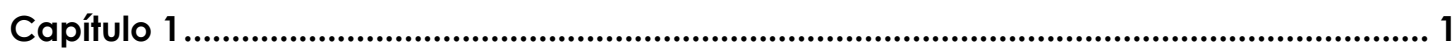

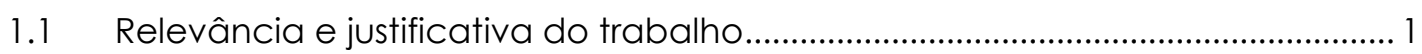

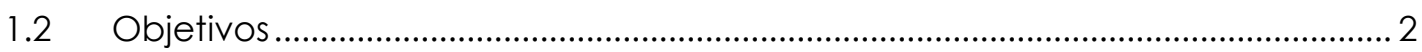

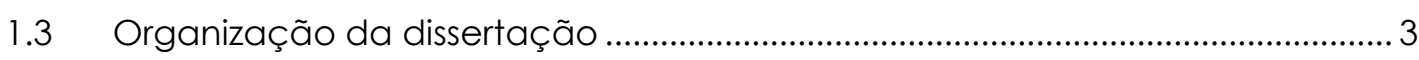

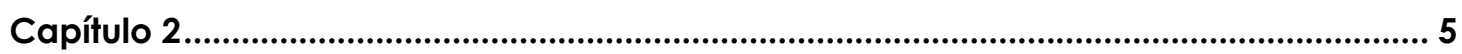

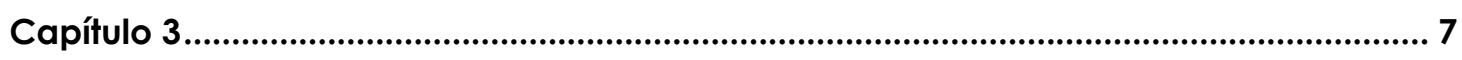

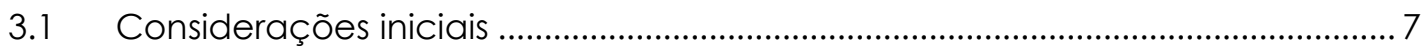

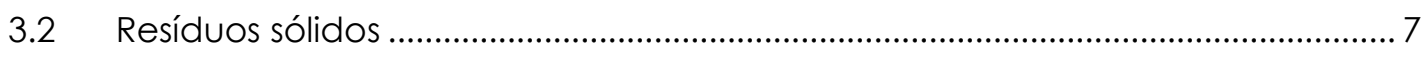

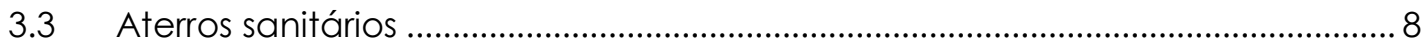

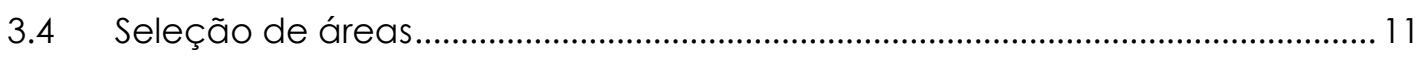

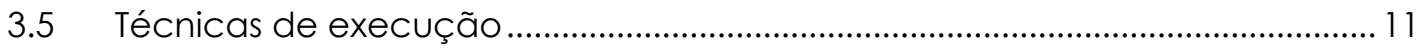

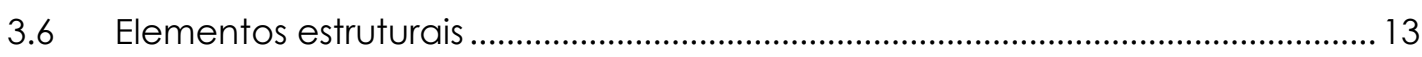

3.7 Barreiras impermeabilizantes com solo compactado ......................................... 15

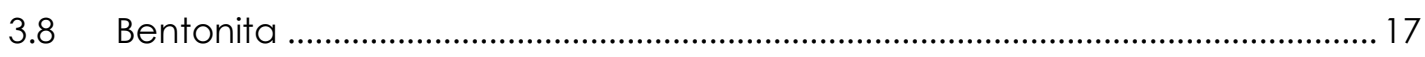

3.9 Barreiras impermeabilizantes de solo-bentonita ................................................ 19

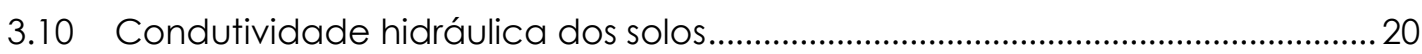

3.11 Ensaios para a determinação da condutividade hidráulica .............................2

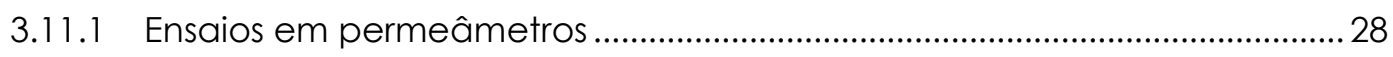

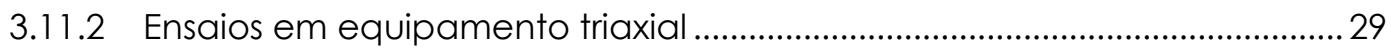

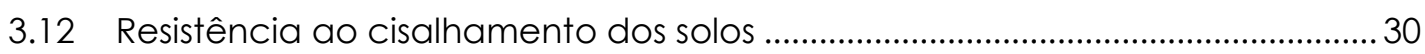

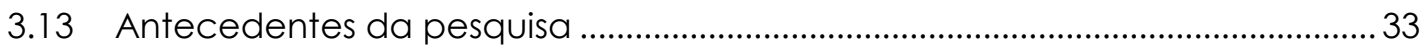




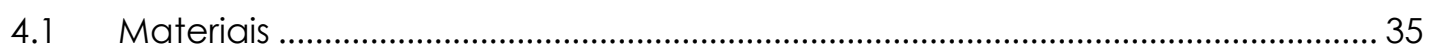

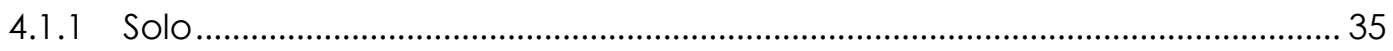

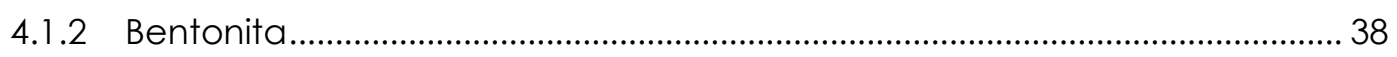

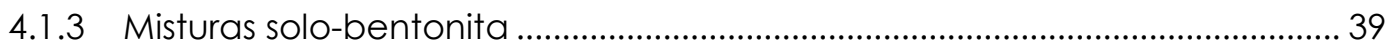

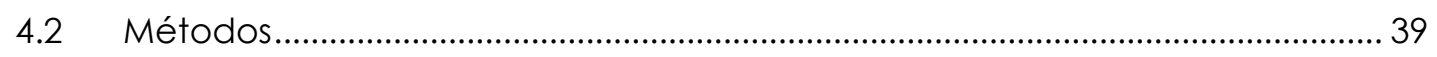

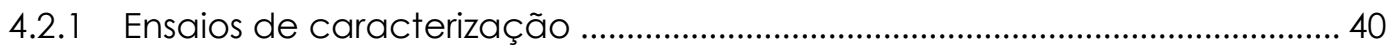

4.2.1.1 Caracterização do solo e das misturas solo-bentonita ........................... 40

4.2.1.2 Ensaios de caracterização da bentonita ...................................................... 40

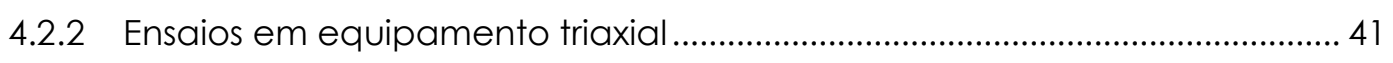

4.2.2.1 Preparação dos corpos de prova .............................................................. 41

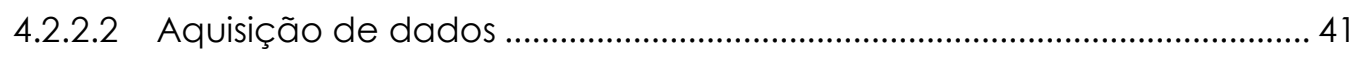

4.2.2.3 Procedimentos de montagem .................................................................. 43

4.2.2.4 Saturação dos corpos de prova ................................................................... 45

4.2.2.5 Condutividade hidráulica antes e após a fase de adensamento........ 46

4.2.2.6 Adensamento e cisalhamento dos corpos de prova .............................. 46

4.2.2.7 Determinação dos parâmetros de resistência ............................................. 46

Capítulo 5 .

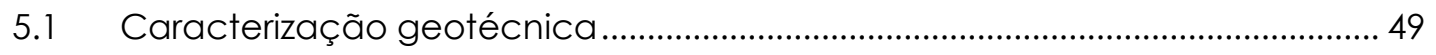

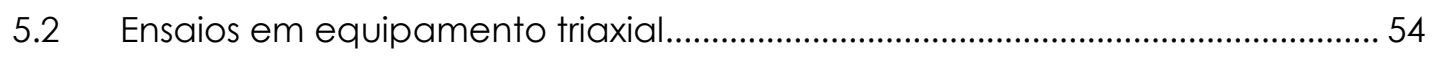

5.2.1 Ensaios para a determinação da condutividade hidráulica antes da fase

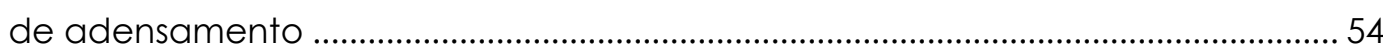

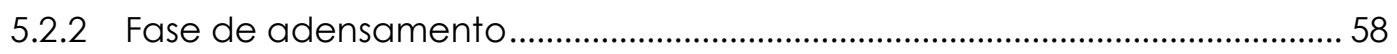


5.2.3 Ensaios para a determinação da condutividade hidráulica após a fase de

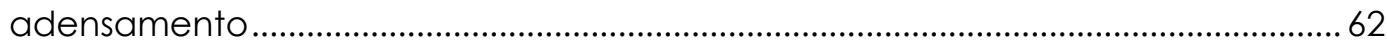

5.2.4 Ensaios para a determinação da resistência ao cisalhamento...................... 65

5.2.5 Critério para a escolha de solos a serem utilizados como barreiras

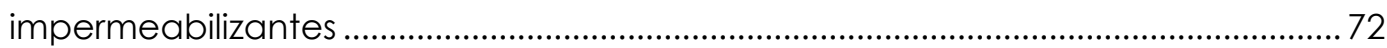

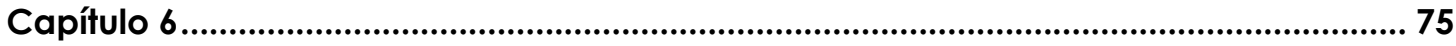

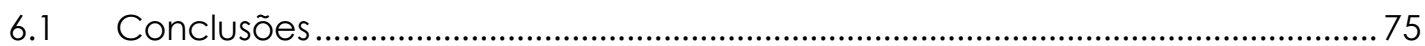

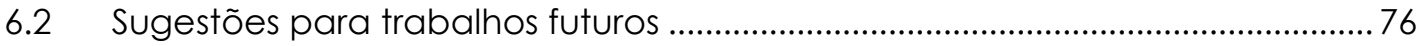





\section{Capítulo 1 \\ Introdução}

\subsection{Relevância e justificativa do trabalho}

A preocupação com a disposição final dos resíduos sólidos data de cerca de 2.500 A. C., quando habitantes da Mesopotâmia já se preocupavam com a destinação do lixo. Esse lixo era enterrado em trincheiras e a matéria orgânica decomposta era utilizada como fertilizante. No entanto, as alternativas para a disposição adequada dos resíduos sólidos só passaram a ser tratadas como um problema de engenharia quando órgãos governamentais passaram a exigir um planejamento que abrangesse custos, seleção de áreas adequadas, métodos de disposição e equipamentos adequados.

Camadas compactadas de solos de granulometria fina são usualmente utilizadas como barreiras hidráulicas para limitar a percolação de líquidos contaminados provenientes de aterros de lixo doméstico e industrial, rejeitos de mineração e barragens de rejeitos tóxicos. Os materiais finos compactados são utilizados isoladamente ou associados com geossintéticos em barreiras hidráulicas e sistemas de coberturas de aterros. Em ambos os casos, a camada argilosa é o material responsável pela manutenção da integridade da barreira. Para o caso das barreiras hidráulicas de fundo, a camada deve possuir uma condutividade hidráulica inferior a 1×10-9 m/s (EPA, 1992; ASTM D 1973, 1991).

Atualmente, têm-se incentivado inúmeras pesquisas sobre as diferentes técnicas de disposição final dos resíduos sólidos. O intuito é ampliar os conhecimentos acerca deste tema e permitir que possam ser realizadas as melhores escolhas de projeto para cada caso. Esta preocupação com a proteção ambiental sofreu um grande impulso, em âmbito nacional, a partir da publicação no Diário Oficial da União, da Lei 9.605 - Lei de Crimes Ambientais de 12/02/1998. Essa lei dispõe sobre sanções penais e administrativas derivadas de condutas e atividades lesivas ao meio ambiente. Além disso, o decreto № 7.404 de 23/12/2010, o qual institui a Política Nacional de Resíduos Sólidos (PNRS), ratifica a 
necessidade da realização da disposição final dos resíduos sólidos de forma ambientalmente adequada.

O tema aterros sanitários ganha relevância ainda maior na zona sul do Estado do Rio Grande do Sul, pois está sendo planejado um projeto, orçado em 15 milhões de reais, para a construção de seis aterros sanitários. Esses aterros deverão beneficiar 20 municípios da região (CABISTANY, 2009). Entretanto, cabe salientar que essa região apresenta deficiência de materiais considerados nobres para uso neste tipo de obra de terra. Com isso, surge a necessidade da realização de pesquisas de materiais alternativos para serem utilizados com tal finalidade.

\subsection{Objetivos}

O principal objetivo deste trabalho é contribuir para o avanço do conhecimento do comportamento hidráulico e mecânico de novos materiais para serem utilizados como barreiras impermeáveis na região de Rio Grande (RS), dando ênfase aos liners de aterros sanitários.

São objetivos específicos desta pesquisa:

1) Avaliar a influência do teor de bentonita na condutividade hidráulica e resistência ao cisalhamento de um solo arenoso da região de Rio Grande (RS);

2) Determinar o teor ótimo de bentonita para o solo estudado, tendo como requisito a condutividade hidráulica;

3) Caracterizar geotecnicamente a mistura proposta como componente principal do liner;

4) Analisar a influência da adição de bentonita nas propriedades de compactação do solo estudado;

5) Analisar a influência do estado de tensões na condutividade hidráulica do material estudado;

6) Apresentar uma alternativa tecnicamente viável para a construção de barreiras de fundo para as próximas células que serão construídas no aterro sanitário do 
município do Rio Grande (RS), bem como para os demais aterros sanitários que deverão ser construídos na em terrenos de geologia similar;

7) Contribuir na busca de materiais alternativos para obras de terra do litoral sul do Estado do Rio Grande do Sul;

8) Implementar um novo procedimento para a aquisição de dados nos ensaios triaxiais no Departamento de Geotecnia da EESC/USP.

\subsection{Organização da dissertação}

A presente dissertação está dividida em seis capítulos. Inicia com a Introdução (Capítulo 1), seguido de um Cenário de Estudo (Capítulo 2). A Revisão Bibliográfica, que é apresentada no Capítulo 3, compreende os tópicos referentes aos principais assuntos abordados neste trabalho. No Capítulo 4 são descritos os Materiais e Métodos utilizados para a realização dos ensaios. No Capítulo 5 apresentam-se os Resultados e Análises dos ensaios. Por fim, no Capítulo 6 estão apresentadas as principais Conclusões obtidas com a análise dos resultados, as quais representam a síntese do conhecimento adquirido com a realização desta pesquisa. 


\section{Capítulo 2 \\ Cenário de estudo}

Como estudo de caso foi selecionado o novo aterro sanitário do município do Rio Grande. O município possui cerca de 200 mil habitantes e está localizado na Planície Costeira Sul do Estado do Rio Grande do Sul, conforme pode ser visto na Figura 2.1.
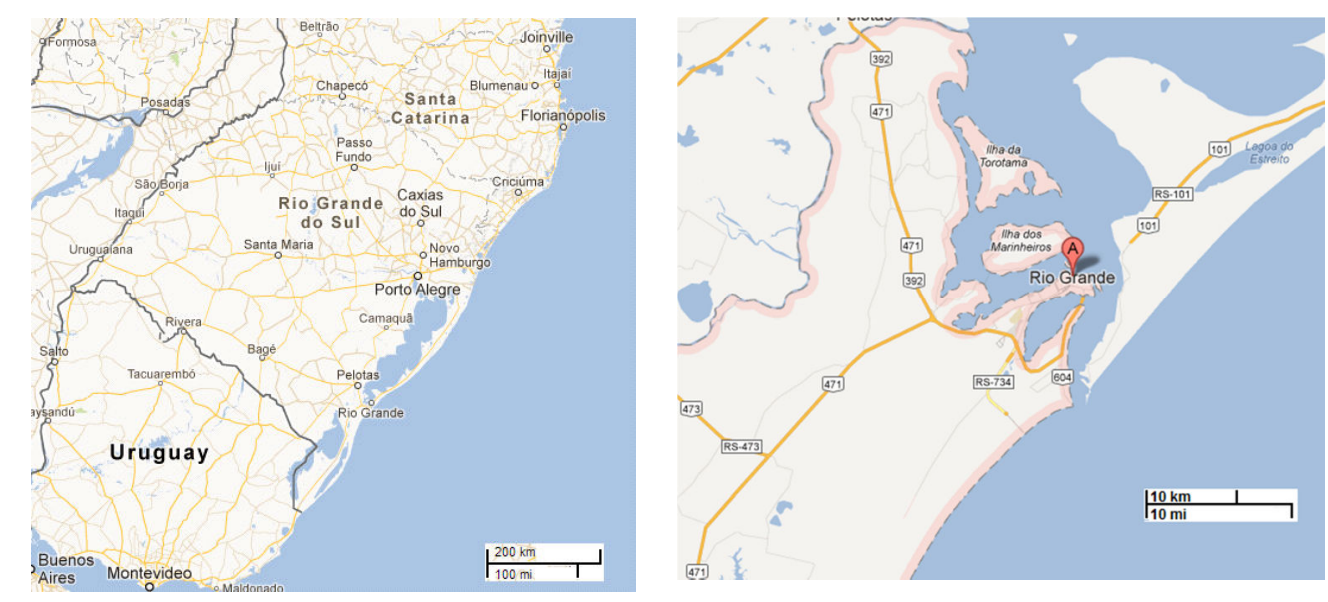

Figura 2.1: Localização do município do Rio Grande/RS.

Características peculiares da região tornam a preservação das águas ainda mais importante no município. O município tem uma rede hidrográfica interna formada por lagoas e arroios, com muitos banhados permanentes e temporários, resultantes da dificuldade de escoamento superficial, em virtude da baixa declividade dos terrenos. Além disso, o fato deste ambiente apresentar uma grande diversidade de vida, devido a sua feição costeira e estuarial, faz com que a preservação da qualidade ambiental seja de fundamental importância (ALMEIDA et al., 1993)

Entretanto, a disposição dos resíduos sólidos do município vinha sendo realizada, até 2009, em um local sem qualquer controle, localizado à margem da Laguna dos Patos. 0 local dista pouco mais de 120 metros da margem da Laguna, fato este que agrava ainda mais os impactos ambientais causados por esta deposição inadequada.

Há alguns anos o município enfrentou dificuldades para encontrar uma alternativa para a disposição dos resíduos sólidos. A solução, encontrada em 2005, foi realizar a 
concessão dos serviços de limpeza pública, repassando os investimentos da construção de um aterro sanitário para uma empresa concessionária (SOUZA, 2007).

A área selecionada para a construção do aterro sanitário está localizada junto ao Km 32 da rodovia BR-392, ao lado esquerdo do eixo, sentido Rio Grande-Pelotas, onde ocorre o cruzamento desta com a Ferrovia Pelotas-Rio Grande. A área total é de 49,6 ha, distando $15 \mathrm{~km}$ do centro da cidade. A área está licenciada ambientalmente para tal atividade. A primeira célula do aterro sanitário está em funcionamento desde o final do ano de 2009. 


\section{Capítulo 3 Revisão bibliográfica}

\subsection{Considerações iniciais}

Para a prevenção da contaminação do lençol freático, muitas vezes, utiliza-se de barreiras impermeáveis de fundo, compostas por solos compactados ou GCLs (Geosynthetic Clay Liners). Esta pesquisa foca no uso de misturas de solo-bentonita compactadas para serem utilizadas na camada de impermeabilização de fundo de aterros sanitários. Desta forma, no decorrer deste capítulo é apresentada uma revisão da literatura a cerca deste tema.

\subsection{Resíduos sólidos}

Segundo a norma brasileira NBR 10.004, "Classificação de resíduos sólidos", recebem a denominação de resíduos sólidos os resíduos nos estados sólidos e semi-sólido que resultam de atividades da comunidade, de origem industrial, doméstica, hospitalar, comercial, agrícola e de varrição. Ficam incluídos nesta definição os lodos provenientes de sistemas de tratamento de água e esgoto, aqueles gerados em equipamentos e instalações de controle de polvição, bem como determinados líquidos cujas particularidades tornem inviável o seu lançamento na rede pública de esgotos ou corpos d'água, ou exijam para isto soluções técnicas e economicamente inviáveis em face à melhor tecnologia disponível.

A NBR 10.004 define as seguintes classes para os resíduos sólidos:

- Classe I-Perigosos: são aqueles que, em função de suas propriedades físicas, químicas e infectocontagiosas, podem apresentar riscos à saúde pública, provocando ou acentuando, de forma significativa, um aumento da mortalidade ou incidência de doenças e/ou riscos ao meio ambiente, quando manuseados ou destinados de forma inadequada; ou ainda 
apresentar características patogênicas, de inflamabilidade, corrosividade, reatividade e toxicidade.

- Classe II - Não perigosos:

Classe IIA - Não inertes: não se enquadram nas classes I (Perigosos) e IIB (Inertes). Podem ter propriedades como biodegrabilidade, combustibilidade ou solubilidade em água.

Classe IIB - Inertes: quando amostrados de uma forma representativa e submetidos a um contato dinâmico e estático com água destilada ou deionizada, à temperatura ambiente, não apresentam nenhum de seus constituintes solubilizados em concentrações superiores aos padrões de potabilidade da água, excetuando-se aspectos de cor, turbidez, dureza e sabor.

\subsection{Aterros sanitários}

Nos últimos anos, tem aumentado o interesse no gerenciamento e na disposição dos resíduos sólidos urbanos (RSU). Políticas de gerenciamento de lixo, adotadas atualmente em todo o mundo, tem envidado esforços para minimizar a produção de lixo, bem como para reciclar e reusar alguns materiais. A Pesquisa Nacional de Saneamento Básico (PNSB), publicada pelo IBGE (2010), mostra que em 2008, $81,3 \%$ de todo o lixo coletado no país foi depositado em aterros sanitários $(64,6 \%)$ ou controlados $(15,7 \%)$.

A NBR 8419/92 define aterro sanitário como um método de disposição de resíduos sólidos no solo, sem provocar prejuízos ou ameaças à saúde ou à segurança. São utilizados princípios de engenharia, de modo a confinar o lixo no menor volume possível. Esse lixo é coberto com uma camada de solo, ao fim de trabalho de cada dia, ou mais frequentemente, se for necessário. Conforme o Manual de Operações de Aterros Sanitários (2002), um aterro sanitário deve ter vida útil superior a 10 anos, prevendo-se ainda o seu monitoramento por alguns anos após o seu fechamento.

No processo de decomposição dos resíduos sólidos, ocorre a liberação de gases e líquidos (chorume ou percolado ou lixiviado) muito polventes. Isso leva o projeto de um 
aterro sanitário a exigir certos cuidados, tais como impermeabilização do solo, implantação de sistemas de drenagem eficazes, entre outros, evitando uma possível contaminação da água, do solo e do ar.

Os resíduos destinados aos aterros sanitários, geralmente, são constituídos por uma parcela considerável de materiais facilmente ou moderadamente degradáveis que sofrem processos de transformações físico-químicas e biológicas, decorrentes da decomposição da matéria orgânica, da qual resulta produção de chorume e gás. Os principais gases gerados são o metano e o dióxido de carbono, sendo que o metano correspondente a $60 \%$ do total produzido na fase anaeróbia. O metano é inflamável quando misturado com oxigênio na proporção de 10 a 15\% (CARVALHO, 1999).

Cabe salientar que é bastante comum certa confusão em relação aos termos aterros sanitários, lixões ou depósitos de resíduos. Nos lixões ou depósitos estão ausentes os critérios científicos ou ecológicos de disposição do resíduo, sendo por isso criticados pelo ponto de vista sanitário (CARVALHO, 1999; LEITE, 1991). No Manual de Operações de Aterros Sanitários (2002) estão descritas as principais diferenças entres lixões e aterros sanitários. Abaixo segue um resumo das principais diferenças.

Quanto à recepção dos resíduos, a entrada é restrita a veículos devidamente cadastrados no aterro sanitário, desde que contenham apenas resíduos permitidos para aquele aterro. No lixão, por sua vez, não há qualquer controle na entrada de veículo e resíduos. Além disso, nos aterros sanitários tem-se controle da entrada através de pesagem, anotação de procedência, composição do lixo, além da observação dos horários de entrada e saída dos veículos.

Nos lixões, o lixo é depositado diretamente sobre a camada de solo, podendo provocar danos ao meio ambiente e à saúde. Já nos aterros sanitários, antes da utilização da célula, o local é devidamente impermeabilizado, seguindo critérios que dependem do solo e do clima do local.

A deposição de resíduos sólidos em aterros sanitários é feita seguindo critérios técnicos definidos, tais como: resíduos dispostos em camadas compactadas, com espessura 
controlada, frente de serviço reduzida e taludes com inclinação definida. Por sua vez, nos lixões, na maioria das vezes, não há sequer um trator de esteira para conformar o lixo.

Quanto à drenagem também ocorrem diferenças substanciais entre um lixão e um aterro sanitário. Nos lixões não há dispositivos para drenagem interna, o que possibilita maior infiltração do chorume na sua base ou o escoamento superficial sem qualquer controle. Nos aterros sanitários existem dispositivos para a captação e drenagem do líquido resultante da decomposição dos resíduos, que previnem a infiltração do chorume no local e o livre escoamento para os corpos receptores (riachos, rios, etc.).

Os aterros sanitários são cobertos diariamente com camada de solo, reduzindo a produção de chorume devido à menor infiltração das águas de chuva. Além disso, esse procedimento impede que o vento carregue o lixo, afastando vetores de doenças. Entretanto, nos lixões não ocorre este procedimento e a exposição do lixo permite a emissão de fortes odores, o espalhamento de lixo leve, além de atrair vetores de doenças (ratos, urubus, moscas, etc.).

Outra grande vantagem dos aterros sanitários é que ele tem seu impacto visual amenizado com a construção de um "cinturão verde" com espécies nativas da região. Este ambiente ainda pode servir como abrigo para predadores de alguns dos vetores.

Zuquette e Pejon (1991) destacam as principais causas da disposição inadequada de resíduos sólidos:

- Falta de conhecimento regional das características do meio físico e do meio ambiente como um todo;

- Não caracterização e separação dos tipos de resíduos;

- Falta de bases mais reais das normas existentes no Brasil para escolha dos locais;

- Baixo índice de estudo em aterros existentes ou experimentais;

- Falta de fiscalização pelos órgãos competentes e punição dos responsáveis pela disposição inadequada dos resíduos;

- Elevados custos de operação. 


\subsection{Seleção de áreas}

Uma das principais dificuldades encontradas na implantação de um aterro sanitário é a escolha de uma área que reúna boas condições técnicas, econômicas e ambientais. Isto é normalmente feito a partir de criteriosa pesquisa de áreas alternativas favoráveis. O estudo de alternativas locais é considerado um importante instrumento de planejamento ambiental, pois muitos impactos ambientais podem ser evitados ou minimizados com a escolha de local adequado para a implantação do empreendimento.

De acordo com Carvalho (1999), devem ser investigadas as condições topográficas, hidrogeológicas e geotécnicas. da área. Também devem ser investigadas a distância de transporte dos centros geradores de RSU, capacidade de disposição, condições de acesso e trafegabilidade, suceptibilidade de contaminação do lençol freático e disponibilidade de solos para recobrimento e proteção, dentre outros fatores.

A CETESB (1993) recomenda algumas restrições na escolha do local de implantação de um aterro sanitário:

- Distância mínima de 500 m de residências, condicionada à direção dos ventos;

- Distância mínima de 200 m de corpos de água superficiais;

- Condutividade hidráulica do subsolo inferior a 10-9 m/s;

- Lençol freático no mínimo a 1,5 metros abaixo da cota de fundo do aterro.

\subsection{Técnicas de execução}

A técnica de execução de um aterro sanitário consiste na compactação do resíduo em células, cuja altura varia de 2 a 4 metros. A inclinação máxima do talude é de 1:2. 0 resíduo deve ser espalhado e compactado pelo talude de baixo para cima, com 3 a 5 passadas do trator de esteira. A compactação, muitas vezes, é também realizada pelo próprio tráfego dos equipamentos de transporte. O processo de compactação, além de aumentar a vida útil do aterro face ao maior volume disposto, auxilia na redução da compressibilidade, na migração de percolados e gases, podendo reduzir os riscos de 
incêndios Após a compactação, o resíduo deve ser recoberto, diariamente, por uma camada que pode ser de solo, de materiais inertes, processados ou não, de materiais processados de aterros antigos e materiais selecionados e triturados. A espessura dessa camada é função do tipo de aterro em execução e da própria composição dos resíduos e deve apresentar espessura mínima de 0,15 m. Este recobrimento visa evitar o arraste de detritos pelo vento, bem como evitar o aparecimento de vetores que possam provocar problemas de saúde pública (TIVERON et al. 1995).

Essa camada intermediária é importante na implantação final do sistema de drenagem superficial e de proteção dos taludes. A estrutura final do aterro é constituída por um conjunto de células adjacentes e sobrepostas, conforme mostrado na Figura 3.1.

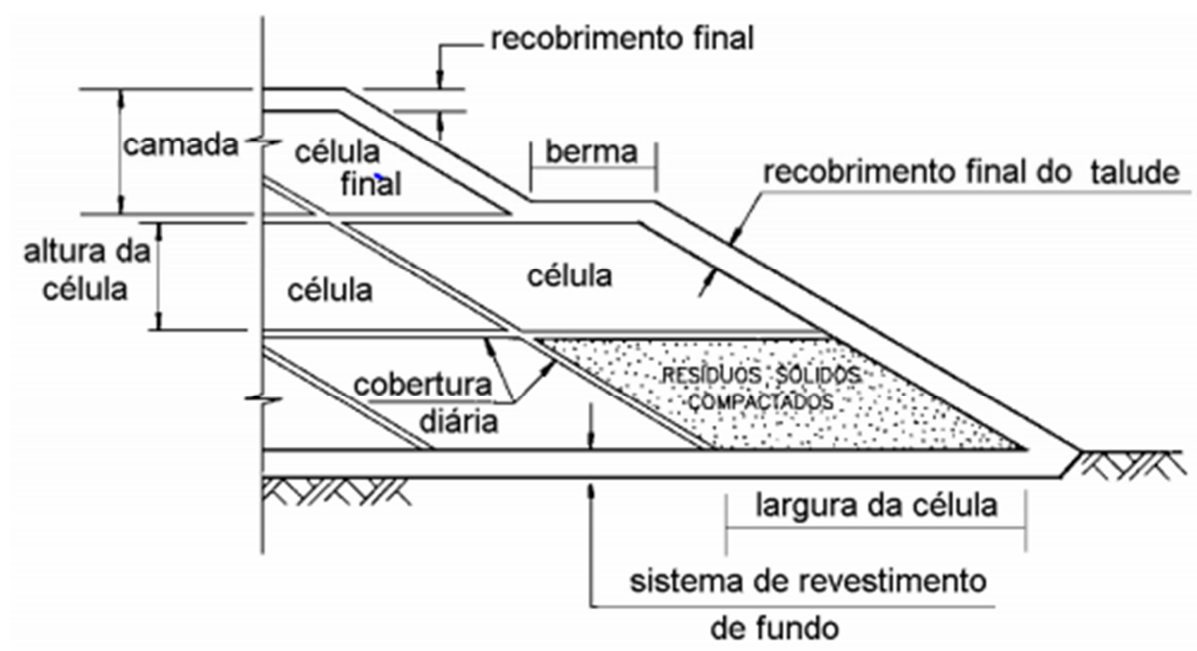

Figura 3.1: Estrutura de um aterro sanitário (ENGECORPS, 1996).

O volume perdido do aterro com os recobrimentos diários chega a representar de 10 a $20 \%$ do volume total do aterro, Uma alternativa seria a utilização de materiais geossintéticos para o recobrimento diário (QUERIO \& LUNDELL, 1992).

Após a conclusão dos trabalhos de disposição dos resíduos no aterro sanitário, uma camada final de recobrimento de argila compactada, de no mínimo 0,6 m, deve ser 
executada, tendo como função: i) diminuir a taxa de formação de percolado; ii) controlar a saída de gases; e iii) servir de camada suporte para algum tipo de empreendimento que porventura venha a ser construído no local (Figura 3.2) (DANIEL, 1998).

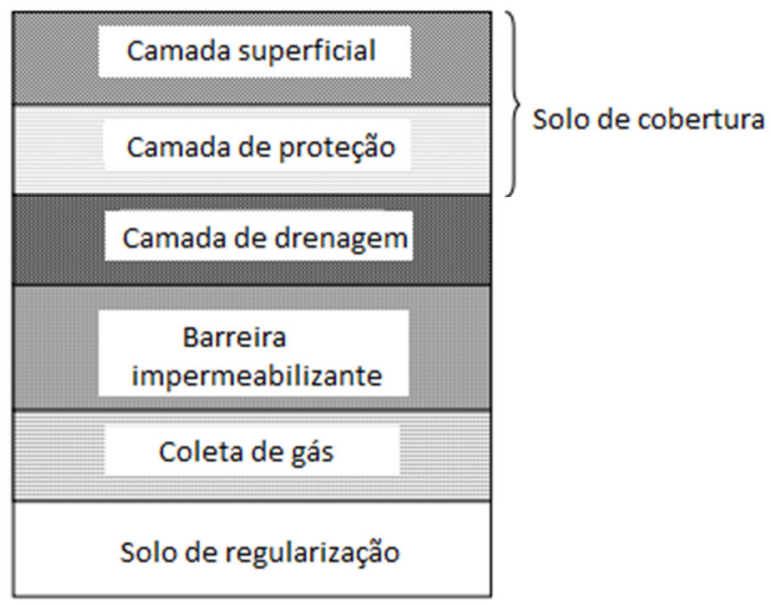

Figura 3.2: Desenho esquemático de cobertura de um aterro sanitário (adaptado de DANIEL, 1998).

\subsection{Elementos estruturais}

Macambira (2002) afirma que a disposição adequada dos resíduos sólidos não é a sua simples estocagem em local pré-estabelecido. Por isso, a maioria dos aterros sanitários é formada por alguns elementos básicos que, em conjunto, aperfeiçoam suas funções. Tais elementos são:

- Revestimento de fundo: corresponde aos tratamentos efetuados ao nível de fundação, para impedir a contaminação dos terrenos e do lençol freático, pelos líquidos e gases efluentes gerados pelos resíduos;

- Célula de resíduo: correspondente ao volume de resíduos sólidos dispostos por um período de lançamento, incluindo o material de recobrimento que a envolve;

- Recobrimento da célula: corresponde à camada de material inerte (solo ou material alternativo) necessária para recobrir totalmente a superfície de uma célula ao final de cada dia de trabalho e tem como objetivo impedir o espalhamento de resíduos; 
- Camada de resíduos: correspondente a um conjunto de células contidas entre duas elevações fixas. A disposição das camadas, uma sobre as outras, forma o aterro;

- Cobertura final ou de fechamento: materiais naturais ou sintéticos utilizados para os fechamentos das últimas células de resíduo, impedindo o contato dos mesmos com o meio ambiente;

- Bermas: corresponde às plataformas e aos terraços horizontais que são executados ao longo das faces dos taludes. Esse tipo de elemento geralmente é executado em aterros com altura superior a 15 metros, desta forma amenizando as inclinações e garantindo maior estabilidade. As bermas são construídas entre todas as camadas de resíduos;

- Sistema de drenagem: vários efluentes, formados no interior do aterro, devem ser retirados e para isso são executados sistemas de drenagem específicos para cada tipo de demanda. Dentre eles pode-se destacar o sistema de drenagem de chorume e de gases;

- Sistema de drenagem e proteção superficial: corresponde ao conjunto de dispositivos de drenagem para captar e conduzir adequadamente as águas superficiais para áreas externas ao aterro, prevenindo assim contra a erosão;

- Sistema de drenagem de nascentes: corresponde ao conjunto de dispositivos de drenagem instalados sob os aterros, visando captar e conduzir de forma adequada todas e quaisquer surgências de água existentes na área do aterro.

A Figura 3.3, mostra o corte da seção de um aterro sanitário, de forma a ilustrar os seus principais componentes. 


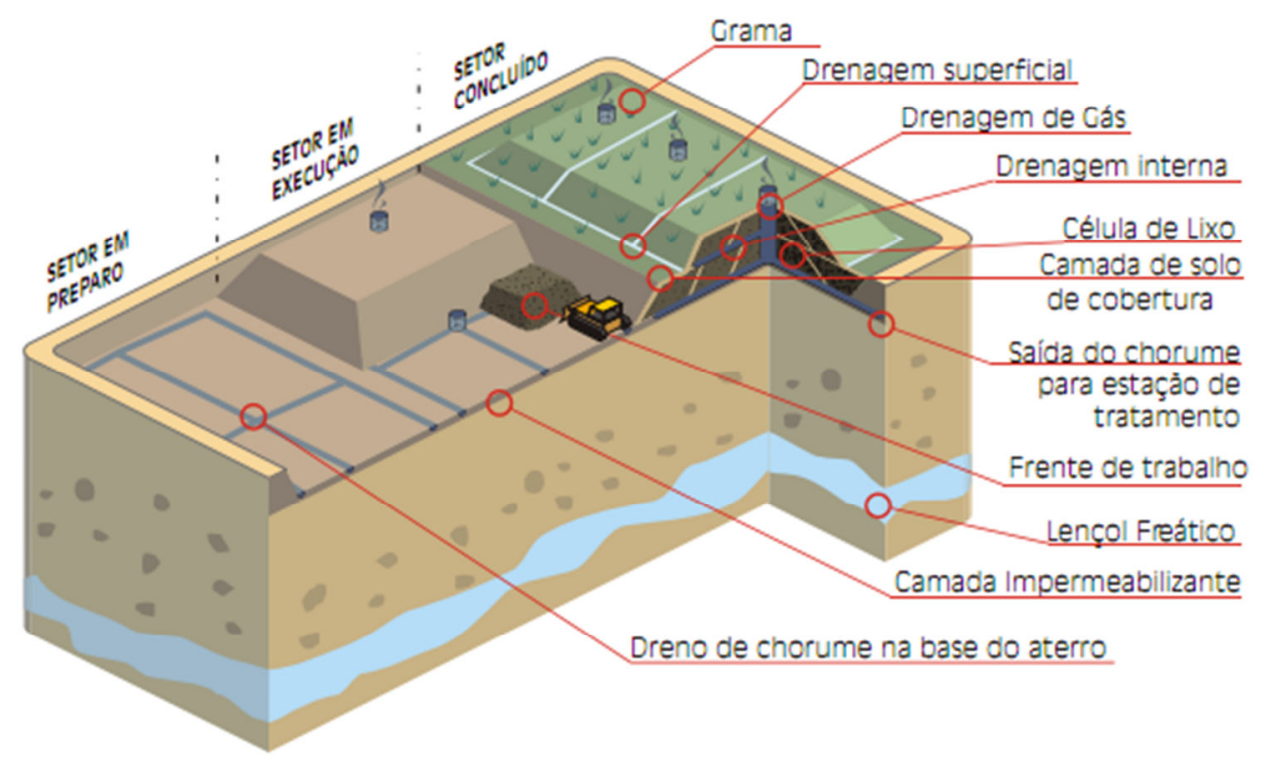

Figura 3.3: Vista de um aterro sanitário (MANUAL DE OPERAÇÕES DE ATERROS SANITÁRIOS, 2002).

\subsection{Barreiras impermeabilizantes com solo compactado}

Na literatura é apontada como um tipo de barreira impermeável aquela constituída de solo compactado, cujo maciço deve apresentar condutividade hidráulica inferior a $10^{-9} \mathrm{~m} / \mathrm{s}$ e estar isento de imperfeições como falhas, trincas ou qualquer descontinuidade que proporcione um caminho preferencial de fluxo (CARVALHO, 1999; MACAMBIRA, 2002; ALONSO, 2005). Normalmente, este tipo de barreira impermeabilizante é construído com solos que apresentam altas porcentagens de argila. Além disso, a espessura mínima sugerida é de 1,0 m (CARVALHO, 1999).

Segundo Daniel (1993), a continuidade e a condutividade hidráulica de um solo usado como impermeabilizante ou revestimento são questionamentos que podem ser esclarecidos com o estudo da evolução geológica do solo e da hidrogeologia local. Tais estudos de continuidade podem ser realizados através de furos de sondagem, ensaios geofísicos, análise de concentração radioisotrópica (determinação da idade da água contida no solo), dentre outros.

MCBEAN et al. (1995) afirmam que a construção de barreiras impermeáveis utilizando solo compactado deve seguir alguns requisitos de execução para garantir o seu bom 
funcionamento: i) as camadas de fundo do aterro devem ser compactadas em faixas horizontais; e ii) nos taludes, é recomendado que as camadas de solo sejam compactadas paralelamente a estes.

Além disso, a compactação deve ser realizada com equipamentos adequados às características do solo que está sendo trabalhado. Na compactação de solos argilosos preferem-se os equipamentos estáticos frente aos vibratórios. Outro cuidado bastante relevante nesta etapa diz respeito à escarificação de uma camada previamente compactada. A escarificação garante uma melhor aderência com a camada sobrejacente. Por fim, recomenda-se também proteger o solo contra o ressecamento, o qual pode causar trincas de contração, as quais, por sua vez, atuarão como caminhos preferenciais de fluxo, prejudicando o adequado funcionamento da barreira impermeabilizante.

De acordo com Boynton e Daniel (1985), muitos são os fatores intervenientes na condutividade hidráulica do um solo compactado. Dentre eles destacam-se: i) teor de umidade de compactação; ii) grau de saturação; iii) o método de compactação; iv) o esforço de compactação; v) o gradiente hidráulico; vi) o tamanho dos aglomerados da partículas de solo; vii) a distribuição dos tamanhos dos poros; viii) a composição química do líquido permeante; ix) a idade da amostra a ser testada; e x) o índice de vazios.

Quanto ao solo selecionado para a construção de uma barreira impermeável, este deve apresentar características que atendam as necessidades desta função, principalmente no que diz respeito à condutividade hidráulica. A CETESB (1993) sugere a adoção de um critério para a escolha do solo a ser utilizado como barreira impermeável:

- Classificação unificada CL, CH, SC ou OH;

- Porcentagem que passa na peneira \#200 maior que 30\%;

- $L P \geq 30 \%$ e $I P \geq 15 \%$;

- $\mathrm{pH} \geq 7$;

- $\mathrm{k} \leq 10^{-9} \mathrm{~m} / \mathrm{s}$.

Cabe salientar que a maioria dos órgãos ambientais internacionais também regulamenta que a condutividade hidráulica seja menor ou igual a $1 \times 10^{-9} \mathrm{~m} / \mathrm{s}$. Segundo 
Potter e Yong (1993) este valor foi definido baseado na lei de Darcy e considerando-se um período de 30 anos, após o qual o lixiviado deixaria de ser polvente e atravessaria a camada compactada de um metro de espessura, considerando o gradiente hidráulico unitário.

Quando o solo com as características necessárias não é encontrado, ou quando a área de empréstimo é demasiadamente afastada, inviabilizando economicamente o uso do material, pode-se lançar mão do uso de aditivos para a melhoria dos solos. Um dos métodos difundidos na literatura é a adição de bentonita com o objetivo de obter baixos valores de condutividade hidráulica.

\subsection{Bentonita}

Bentonita é uma argila formada pela alteração das cinzas vulcânicas tendo como principal constituinte $\mathrm{O}$ argilomineral montmorilonita. $\bigcirc$ nome bentonita foi adotado em função do depósito de folhelhos argilosos descoberto em Fort Benton, Wyoming (EUA), onde esse material foi pela primeira vez identificado como um tipo especial de argila (SANTOS, 1989).

Do ponto de vista químico, as bentonitas são filossilicatos hexagonais de alumínio e magnésio hidratados. Elas possuem na sua constituição cátions trocáveis, que são derivados do desbalanceamento de cargas de sua estrutura. Esse fato ocorre durante o intemperismo ácido na formação do argilomineral montmorilonita. Todos os tipos de bentonita possuem um ou vários argilominerais do grupo da esmectita, com a montmorilonita como argilomineral predominante. As argilas constituídas por esses argilominerais possuem elevada plasticidade e apresentam grandes variações nas suas propriedades físicas. Tais variações ocorrem devido à existência de cátions trocáveis hidratados na sua estrutura e às alterações que ocorrem nas posições octaédricas do argilomineral (MITCHELL, 1983). A Figura 3.4 apresenta a estrutura cristalina da montmorilonita. 


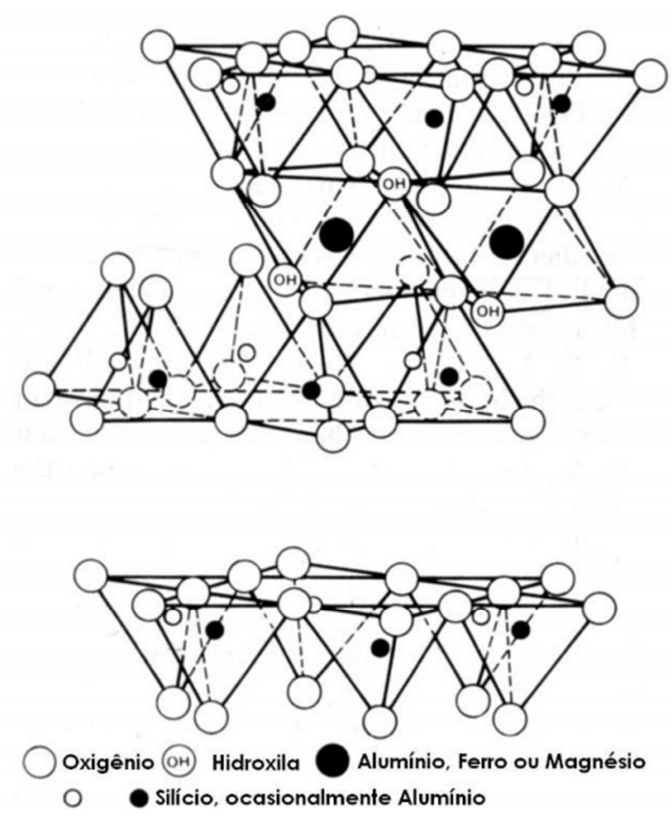

Figura 3.4: Estrutura cristalina da montmorilonita (adaptado de MITCHELL, 1993).

No caso de um cátion trivalente ser substituído por um cátion divalente, ocorrerá um excesso de elétrons, que migrarão para a superfície à procura de cátions de equilíbrio. Os cátions trocáveis presentes no ambiente de formação podem ser: $\mathrm{Ca}^{+2}, \mathrm{Mg}^{+2}, \mathrm{Na}^{+1}$, entre outros. O cátion predominante na estrutura vai originar o nome do argilomineral (Ex.: bentonita cálcica, bentonita sódica), e será determinante no desempenho desejado da bentonita e nas propriedades desta. A bentonita sódica é mais comumente utilizada em obras de selagem e impermeabilização, devido ao fato de possuir um poder muito maior de expansão que a bentonita cálcica. Por outro lado, a bentonita cálcica é mais estável quimicamente quando exposta a alguns compostos químicos (MITCHELL, 1983).

A qualidade de uma bentonita pode ser avaliada através dos limites de Atterberg e de ensaios de expansão livre. Quanto maior for o limite de plasticidade e o limite de liquidez, melhor será a bentonita. O limite de liquidez de uma bentonita cálcica varia entre 100 e $150 \%$ enquanto que o de uma bentonita sódica varia entre 300 e 500\%. Os testes de expansão livre mostram que quanto maior a capacidade de expansão de uma bentonita melhor a sua qualidade (DANIEL \& KOERNER, 1995).

A elevada afinidade da bentonita com água e sua alta capacidade de expansão são características que conferem a este material resistência à passagem de água. Em 
condições confinadas, as partículas expandidas são forçadas entre si de maneira que ocorra o preenchimento dos vazios entre as partículas do solo, formando uma barreira contra a passagem do fluxo (GLEASON et al., 1997).

$\mathrm{O} \mathrm{pH}$ afeta fortemente a expansão livre da bentonita, sendo que as bentonitas sódicas são as mais afetadas por este fator. A expansão máxima da argila ocorre em um meio de pH aproximado de 8. Além disso, a redução da expansão, associada à redução do $\mathrm{pH}$, provoca uma redução da dupla camada de íons, aumentando, consequentemente, a condutividade hidráulica. Considerando-se que em um meio contaminado poderá existir uma grande variação de pH, a probabilidade de ocorrência de variação de condutividade hidráulica em aterros contendo bentonita sódica é elevada (KHERA, 1995).

No Brasil, a reserva de bentonita é da ordem de 83 milhões de toneladas, sendo que 51,4\% destas são reservas medidas, as quais estão assim distribuídas: $39 \%$ no Estado do Paraná, município de Quatro Barras; 23,4\% no Estado da Paraíba, no município de Boa Vista; e 15,6\% no Estado do Piauí, no município do Guadalupe (BATISTA, 2006).

\subsection{Barreiras impermeabilizantes de solo-bentonita}

Desde a década de 70, países como os Estados Unidos, Alemanha, Suíça e França, utilizam como solução uma camada conhecida como barreira ativa. Essas barreiras são camadas tratadas com bentonita, especialmente desenvolvidas para a impermeabilização de solos, garantindo proteção constante mesmo em condições adversas. Essas barreiras ativas são constituídas por um tipo de bentonita que possui propriedades expansivas e de cicatrização superior às demais bentonitas (GOUVEIA, 2005 apud LUKIANTCHUKI, 2007).

O emprego dessas barreiras ativas pode ser realizado em obras com ou sem a utilização de mantas protetoras. No caso de obras que utilizem mantas protetoras, a camada ativa funciona como camada de segurança, colocada abaixo da manta protetora, para caso ocorra falhas no sistema. Naquelas obras em que não se utilizam mantas protetoras, a camada ativa é utilizada como proteção total do sistema, sendo que 
em alguns tipos de obra colocam-se duas ou mais camadas de mistura, formando assim um sanduíche de camadas (GOUVEIA, 2005 apud LUKIANTCHUKI, 2007).

Existe uma proporção adequada de bentonita a ser adicionada no solo e que esta varia entre 4 e 10\%. Entretanto, não se deve utilizar apenas este parâmetro e sim realizar ensaios para determinar o teor ótimo de bentonita para cada caso (ROWE, 2000).

Daniel (1993) recomenda o acréscimo de bentonita a um solo, quando este apresenta características inadequadas para a construção de barreiras impermeáveis. De acordo com esse autor, uma pequena quantidade de bentonita pode acarretar uma diminuição em várias ordens de grandeza no valor da condutividade hidráulica de determinado solo. A Figura 3.5 apresenta, como exemplo, a variação de condutividade hidráulica em relação ao teor de bentonita adicionado a um dado solo.

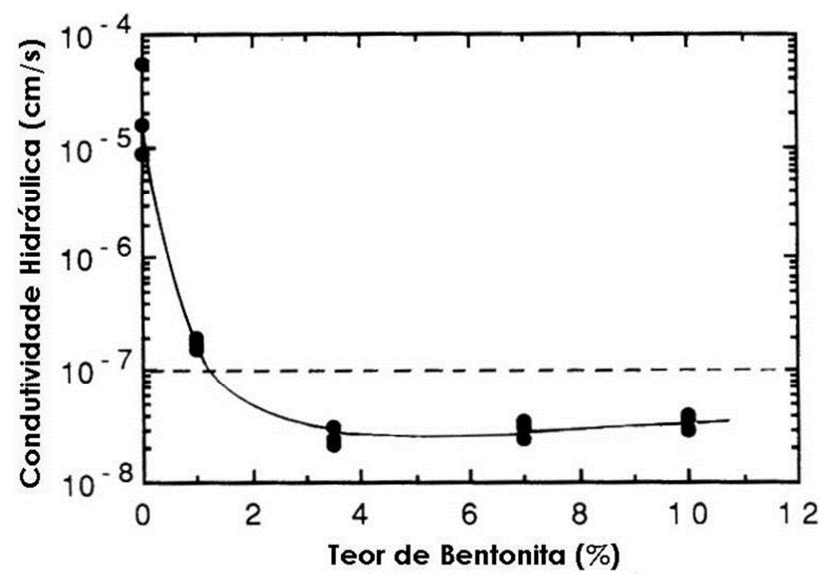

Figura 3.5: Variação da condutividade hidráulica com o teor de bentonita (adaptado de DANIEL, 1993).

\subsection{Condutividade hidráulica dos solos}

O estudo das propriedades e do comportamento dos solos é necessário em qualquer projeto em que eles venham a ser utilizados, tanto nos casos em que o solo é utilizado como fundação como nos casos em que é utilizado como material de construção. No caso específico das barreiras impermeabilizantes, a condutividade hidráulica é um fator decisivo 
na escolha do material uma vez que na construção é necessária a utilização de materiais com baixíssimos valores de condutividade hidráulica.

Henry Darcy (1856) apud Lukiantchuki (2007) publicou um trabalho referente ao estudo do movimento de água em um filtro de areia. Através desta pesquisa, ele conseguiu definir a Equação 3.1, conhecida como Lei de Darcy:

$v=k \times i$

A velocidade $v$ de descarga de um fluído através de um meio poroso é diretamente proporcional ao gradiente hidráulico $i$. A constante de proporcionalidade $k$ é denominada coeficiente de condutividade hidráulica. O gradiente hidráulico $i$ é definido pela Equação 3.2.

$i=\frac{\Delta h}{l}$

Na equação acima, $\Delta h$ é a perda de carga do fluído percolante em um trecho de comprimento $l$. A condutividade hidráulica $(k)$ é um parâmetro característico do meio poroso e do fluído que percola por este meio. Para um caso genérico onde percola-se através de um meio poroso fluído com densidades e viscosidades distintas, o valor de $k$ obtido será diferente para cada caso. Considerando-se outro caso genérico, onde o fluído percolado seja o mesmo, porém em meios porosos diferentes, os valores de $k$ são diferentes. A Lei de Darcy pode ser escrita de acordo com a Equação 3.3, sendo $\gamma$ e $\mu$ o peso específico e a viscosidade do líquido percolante, respectivamente. $K$ é a permeabilidade intrínseca do solo, uma propriedade que é função exclusiva do meio poroso.

$v=\frac{K \times \gamma \times i}{\mu}$

A condutividade hidráulica de um solo varia de acordo com os vazios presentes no material, sendo que quanto menor o tamanho das partículas, menor será o tamanho dos vazios no solo e menor a condutividade hidráulica deste. A condutividade hidráulica é um dos parâmetros que apresenta a maior variação em solos, conforme mostrado na Tabela 3.1. A Tabela 3.2 apresenta a classificação do grau de condutividade hidráulica dos solos baseada nos valores do coeficiente de condutividade hidráulica. 
Tabela 3.1: Valores típicos de condutividade hidráulica (PINTO, 2000).

\begin{tabular}{c|c}
\hline Tipo de material & Coeficiente de condutividade hidráulica $(\mathrm{m} / \mathbf{s})$ \\
\hline Argilas & Menor que $10^{-11}$ \\
Siltes & $10^{-10}$ a $10^{-11}$ \\
Areias argilosas & $10^{-9}$ \\
Areias finas & $10^{-7}$ \\
Areias médias & $10^{-6}$ \\
Areias grossas & $10^{-8}$ \\
\hline
\end{tabular}

Tabela 3.2: Classificação dos solos baseado nas condutividades hidráulicas (MITCHEL, 1993).

\begin{tabular}{c|c}
\hline Grau de condutividade hidráulica & Condutividade hidráulica $(\mathbf{m} / \mathbf{s})$ \\
\hline Alta & Maior que $10^{-3}$ \\
Média & $10^{-3}$ a $10^{-5}$ \\
Baixa & $10^{-5}$ a $10^{-7}$ \\
Muita baixa & $10^{-7}$ a $10^{-9}$ \\
Praticamente impermeável & Menor que $10^{-9}$ \\
\hline
\end{tabular}

Muitos estudos acerca dos fatores que afetam a condutividade hidráulica de um solo vêm sendo desenvolvidos nas últimas décadas. D'Appolonia (1980) constatou que a granulometria do solo utilizado na mistura com bentonita para composição de uma barreira mineral é um fator muito importante a ser considerado na condutividade hidráulica resultante da mistura. Segundo esse autor, quanto menor a condutividade hidráulica do solo utilizado, menor será a condutividade hidráulica obtida para a mistura. Sendo assim, solos que possuem maior porcentagem de finos plásticos na sua constituição irão apresentar menores valores de condutividade hidráulica.

Entretanto, outros estudos sobre barreiras de contenção têm indicado a substituição de certa porcentagem de argila constituinte do liner por um material arenoso (GRAHAM et al, 1989; YAN REE et al., 1992; HAN, 1996; ALSTON et al. 1997). Segundo esses autores, tal mistura originaria um material com propriedades melhoradas, tais como menor tendência à contração do que argilas puras e siltes, índice de vazios baixo, estabilidade climática e maior facilidade de construção. 
De acordo com Kozicki et al. (1994), as vantagens dos liners de materiais arenosos com bentonita são: i) apesar da molhagem inicial ser bastante rápida, é necessário um longo período de tempo para que a frente de saturação atravesse o liner; ii) a condutividade hidráulica do liner irá diminuir com a carga ou tensão confinante, reduzindo a taxa de infiltração; e iii) irá ocasionar uma redução significativa na concentração do líquido permeante, como consequência da dispersão, difusão e absorção dentro da matriz.

Existem na literatura duas explicações para a influência do teor de umidade de compactação na condutividade hidráulica de solos argilosos compactados. A primeira, proposta por Lambe (1958), relaciona a condutividade hidráulica do solo compactado com a orientação das partículas de solo. A teoria dos agregados de partículas, proposta por Olsen (1962), sugere que a maior parte do fluxo de água em solos argilosos compactados ocorre nos espaços existentes entre os aglomerados.

Benson e Daniel (1990), na tentativa de verificar a importância da estrutura e dos aglomerados de partículas na condutividade hidráulica de uma argila compactada, estudaram o material a nível microscópico. Não foi encontrada nenhuma evidência de floculação ou dispersão na estrutura do solo em função do teor de umidade de compactação. Segundo os autores, para que a condutividade hidráulica de uma argila compactada seja minimizada em solos argilosos altamente plásticos, que formam aglomerados de partículas, é necessário que os vazios entre os aglomerados sejam eliminados durante a compactação. A eliminação dos aglomerados pode ser feita através da adição de uma quantidade de água suficiente para que os mesmos fiquem menos resistentes pela redução de sucção ou através da aplicação de uma energia de compactação suficientemente alta para destruir os aglomerados secos e resistentes.

A estrutura do solo, as condições e os métodos de compactação foram algumas das variáveis estudadas por Mitchel et al. (1965). As análises foram realizadas com uma argila siltosa, compactada de forma estática, com variação de umidade de moldagem e massa específica seca constante. Com a realização destas análises, os autores concluíram que a condutividade hidráulica dos pontos mais secos aumentou pouco com o aumento do teor 
de umidade. Entretanto, para teores de umidade acima do ótimo, a condutividade hidráulica diminuiu bruscamente (variação de até três ordens de grandeza).

Lambe \& Whitmann (1969) analisaram os efeitos da variação do teor de umidade na condutividade hidráulica de uma argila siltosa jamaicana. Os autores constataram que a condutividade hidráulica diminuiu bruscamente para os pontos com teor de umidade abaixo do teor ótimo. Já para as umidades acima da ótima, tal parâmetro permaneceu praticamente constante, com um aumento pouco expressivo. Segundo os autores, este aumento, provavelmente, se justifica pela orientação das partículas, que nesta situação é considerada paralela.

Benson \& Daniel (1990) estudaram parâmetros limitantes para a obtenção de valores pré-estabelecidos de condutividade hidráulica para a utilização, principalmente, como barreira impermeabilizante em aterros sanitários. Os autores utilizaram a metodologia proposta por Mundell \& Bailey (1985) e Boutweel \& Hedges (1989), nas quais é recomendada a análise da curva de compactação do solo obtida através do Ensaio de Proctor. Com este intuito, esses autores analisaram alguns fatores que restringem os valores de teor de umidade e peso específico seco do solo.

A proposta de Mundell \& Bailey (1985) e Boutweel \& Hedges (1989) define uma área ideal (Figura 3.6), a qual é frequentemente denominada de zona admissível. A zona admissivel é representada pela combinação de valores de massa específica seca e teor de umidade, os quais garantem certos valores desejados de condutividade hidráulica, contração e resistência ao cisalhamento. Segundo a proposta destes autores, o teor de umidade varia entre 0 e $+4 \%$ que o teor de umidade ótimo e a massa específica seca do solo assume valores entre um valor mínimo e um valor máximo que coincide com a curva de saturação do solo. Geralmente, adota-se para esta porcentagem, mínima da massa específica seca do solo 95\% da massa específica seca no Ensaio de Proctor Normal (ASTM D698) ou $90 \%$ no Ensaio de Proctor Modificado (ASTM D-1557). 


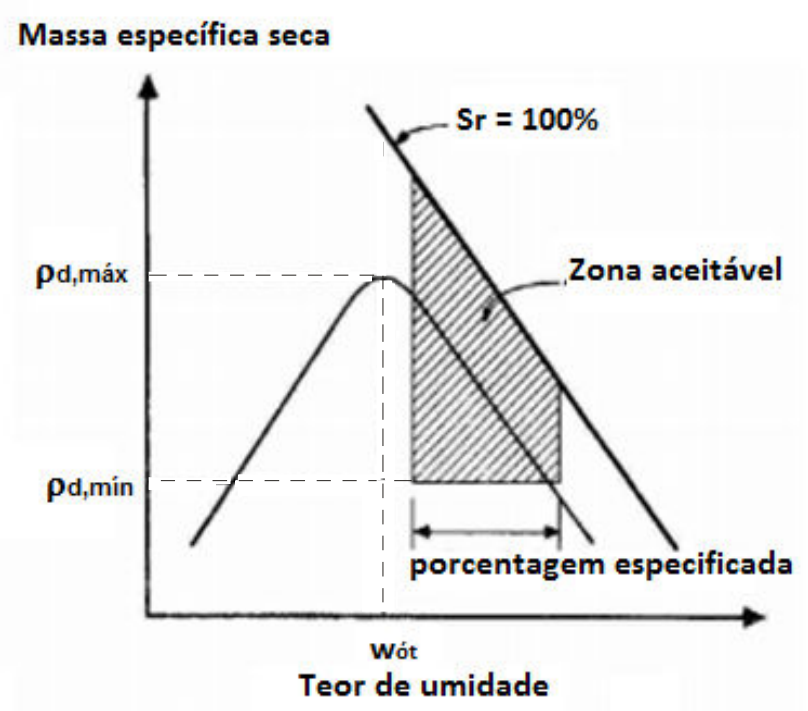

Figura 3.6: Método tradicional para especificação da zona admissível mediante teor de umidade e peso específico seco de solos argilosos (adaptado de DANIEL \& BENSON, 1999).

A diferença de porcentagens admitidas nos diferentes ensaios de compactação justifica-se pelo fato de que a energia de compactação aplicada e o método utilizado influenciam significativamente a condutividade hidráulica (MITCHELL et al, 1965). Porém, a realização de muitos estudos tem mostrado que a combinação entre teor de umidade e o peso específico seco dentro da zona admissível não representa em todas as situações solos argilosos com condutividade hidráulica menor que $1 \times 10^{-9} \mathrm{~m} / \mathrm{s}$, mas sim valores maiores. Dentro deste contexto, recomenda a aproximação de valores, modificando, assim, também os resultados da condutividade hidráulica. Desta forma, Benson \& Daniel (1990) recomendam alguns procedimentos adicionais, os quais estão descritos abaixo:

a) Compactar o solo no laboratório com energias de compactação do Proctor Modificado, Normal e Reduzido desenvolvendo, assim, várias curvas de compactação, como mostra a Figura 3.7a, devendo-se compactar de cinco a seis corpos de prova para cada energia;

b) Os corpos de prova compactados devem ser percolados para determinar a condutividade hidráulica. Este procedimento deve ser cuidadosamente executado. Deve-se também medir o grau de saturação e a tensão confinante efetiva para cada um dos corpos de prova. As medidas de 
permeabilidades devem ser plotadas em função do teor de umidade como mostra a Figura 3.7b.

c) Aqueles corpos de prova que apresentarem o valor de condutividade hidráulica admissível pelos órgãos ambientais (inferior a $10^{-9} \mathrm{~m} / \mathrm{s}$ ) devem ser plotados no gráfico com símbolos diferentes daqueles que não atendem este requisito. Desta forma, a zona admissível é traçada de forma que os ensaios cujos resultados de condutividade hidráulica que atendem os requisitos das normas ambientais estejam nela contidos (Figura 3.7c).

d) Deve-se modificar a zona admissível de acordo com parâmetros que a afetem, como resistência ao cisalhamento, atrito interfacial com geomembranas, considerações de umedecimento e secagem, aparecimento de fissuras, interesses construtivos e práticas locais, conforme ilustra a Figura 3.7d.

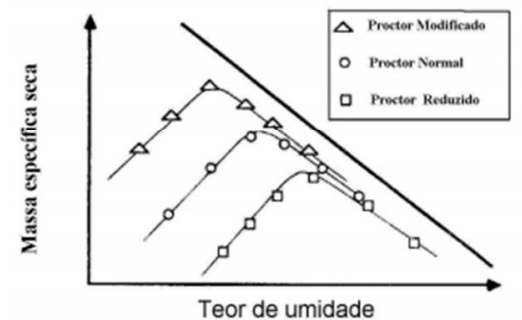

(a)

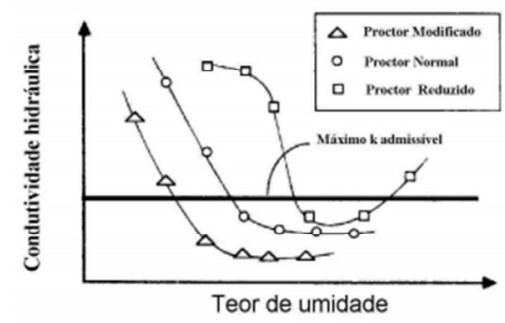

(b)

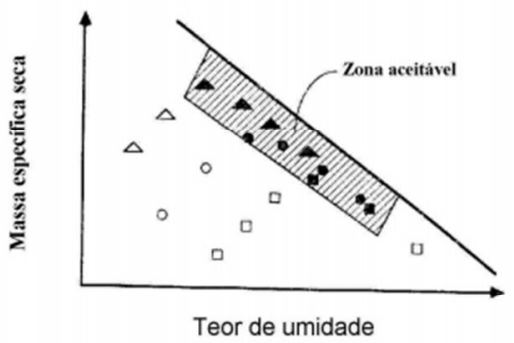

(c)

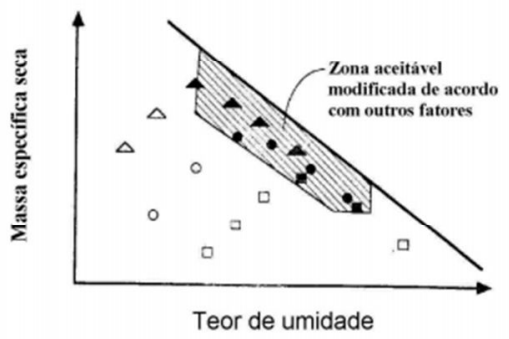

(d)

Figura 3.7: Recomendações de projeto (adaptado de BENSON \& DANIEL, 1990).

Daniel e Wu (1993) acrescentaram mais dois parâmetros restritivos a esta análise: contração e resistência ao cisalhamento. Os valores propostos pelos autores como limítrofes para a determinação da área aceitável para a execução das barreiras são de $4 \%$ de contração volumétrica e a resistência ao cisalhamento, além de $10^{-9} \mathrm{~m} / \mathrm{s}$ de condutividade 
hidráulica. Levando-se em considerações estes valores limítrofes, a zona admissível final é a sobreposição de cada uma das áreas recomendadas individuais, obtidas para cada fator, como mostra a Figura 3.8.

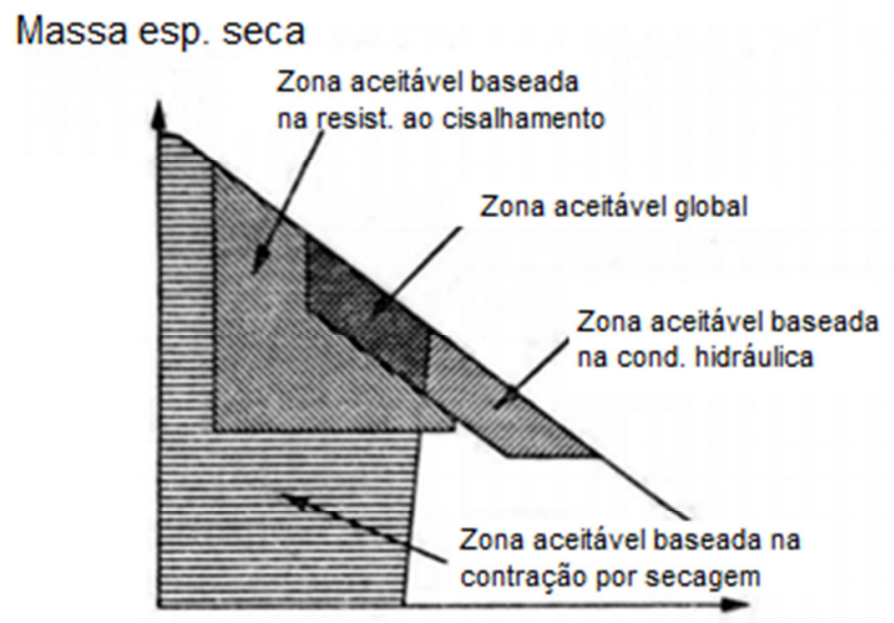

Teor de umidade

Figura 3.8: Área aceitável baseada na condutividade hidráulica, contração volumétrica e resistência ao cisalhamento (adaptado de DANIEL \& WU, 1993).

\subsection{Ensaios para a determinação da condutividade hidráulica}

Nos solos, a condutividade hidráulica apresenta grande variação: de valores da ordem de $10 \mathrm{~m} / \mathrm{s}$, para materiais como pedregulhos, até $10^{-10} \mathrm{~m} / \mathrm{s}$, para materiais com presença de argilas de alta atividade. Por isso, há a necessidade na Engenharia Geotécnica da mensuração desta propriedade dos solos. Existem várias técnicas para determinação deste parâmetro, abrangendo tanto ensaios de campo, quanto de laboratório.

De acordo com Daniel et al. (1984) os ensaios em laboratório, quando comparados com ensaios de campo, apresentam algumas vantagens: i) controle nas condições de contorno (saturação, nível de tensões efetivas, carga hidráulica e direção do fluxo); ii) possibilidade de medidas de anisotropia; iii) tempo de ensaio; iv) custo de ensaio.

Entretanto, Daniel (1987) pondera que os ensaios de campo sofrem um menor efeito de escala, pois o volume de solo ensaiado é maior que em laboratório. Além disso, segundo o mesmo autor, ocorrem variações nas determinações de campo e em laboratório, causadas principalmente por problemas de amostragem. 


\subsubsection{Ensaios em permeâmetros}

Para a determinação da condutividade hidráulica em laboratório, tradicionalmente, utiliza-se algum tipo de permeâmetro. Os permeâmetros se classificam em dois grupos: permeâmetro de parede rígida e permeâmetro de parede flexível. Embora existam diversas variações para cada um deles. A escolha de um determinado equipamento depende: i) das condições contorno a serem utilizadas; ii) o tipo de material a ser ensaiado; iii) as condições de pressão e; iv) do fluído percolante.

Os permeâmetros de parede rígida, geralmente, são utilizados para ensaio de materiais granulares (solos não-coesivos), os quais apresentam alta condutividade hidráulica. Tais equipamentos são constituídos por um tubo de material rígido, o qual pode ser metal, plástico ou até mesmo vidro, no qual a amostra fica confinada lateralmente (DANIEL, 1994).

As amostras ensaiadas nesse tipo de equipamento apresentam menor expansividade do que as amostras ensaiadas em permeâmetros de parede flexível. Entretanto, apresentam algumas desvantagens: i) a impossibilidade da saturação total da amostra; ii) a impossibilidade da saturação por contra-pressão; iii) a inexistência de controle sobre as tensões atuantes na amostra; iv) a possibilidade de ocorrer fluxo lateral pelas paredes do tubo do permeâmetro.

A norma ASTM D 5084/90 recomenda que o permeâmetro de parede flexível seja utilizado para a determinação da condutividade hidráulica de materiais porosos, com valores inferiores ou iguais a $10^{-5} \mathrm{~m} / \mathrm{s}$.

De acordo com Daniel (1994), os permeâmetros de parede flexível são utilizados para materiais com baixa condutividade hidráulica, tais como argilas e materiais cimentados. Neste tipo de permeâmetro, o confinamento da amostra é feito por meio de uma membrana flexível. A amostra é colocada em uma célula, a qual é preenchida com um líquido (geralmente água) e aplica-se uma pressão de modo a confinar a amostra. Ao aplicar-se a pressão, a membrana é pressionada contra a amostra, o que evita o fluxo lateral. 
Além disso, a determinação da condutividade hidráulica utilizando-se permeâmetros de parede flexível apresenta como vantagens: i) as amostras indeformadas podem ser facilmente testadas; ii) a contra-pressão pode ser utilizada para saturar as amostras; iii) as tensões verticais e horizontais podem ser facilmente monitoradas; iv) são mais rápidos quando comparados com os ensaios realizados em permeâmetros de parede rígida.

Entretanto, a amostra ensaiada nem sempre representa a situação real de campo, podendo ocorrer alguns erros durante a realização dos ensaios, tais como: introdução de ar na amostra saturada, adensamento do corpo de prova, entre outros.

\subsubsection{Ensaios em equipamento triaxial}

Segundo Head (1984), o equipamento triaxial permite a manutenção de um fluxo de água através da amostra, sob uma diferença de pressão e taxa de fluxo conhecidas, enquanto a amostra é submetida a uma determinada tensão efetiva. Com a realização das medições, pode-se calcular a condutividade hidráulica da amostra. Além disso, repetidos testes, após a consolidação e para variadas tensões efetivas, podem ser realizadas na mesma amostra, sem ter que retirá-la.

Ainda de acordo com o mesmo autor, algumas das vantagens da determinação da condutividade hidráulica em uma célula triaxial são as seguintes:

- A amostra pode ser primeiramente saturada sob a aplicação de uma contrapressão, o que vai reduzir ou até mesmo eliminar as obstruções ao fluxo causadas por bolha de ar. A presença de ar leva a resultados irreais e ao acúmulo de bolhas na saída da amostra;

- A saturação por contrapressão é atingida muito mais rapidamente do que a saturação por inundação prolongada ou apenas por circulação. Isso se aplica, particularmente, a solos compactados;

- Os ensaios podem ser realizados em condições de tensão efetiva e pressão intersticial relacionadas às condições de campo;

- Mesmo pequenas taxas de fluxo podem ser medidas facilmente; 
- Podem ser utilizados tanto os procedimentos de carga constante quanto de carga variável;

- Uma diversa gama de gradientes hidráulicos pode ser aplicada e medida com precisão;

- Mesmo solos de média condutividade hidráulica, como os siltes, também podem ser satisfatoriamente ensaiados;

- Ensaios com amostras indeformadas podem ser facilmente preparados e não apresentarão efeito causado pela parede da célula, o que poderia levar a condições de fluxo não uniforme.

\subsection{Resistência ao cisalhamento dos solos}

Segundo Lukiantchuki (2007), a avaliação do comportamento de um material para a construção de uma barreira impermeabilizante levando-se em consideração somente a condutividade hidráulica e, portanto, desprezando-se os parâmetros de resistência, poderá ocasionar sérios danos ao comportamento dessas. Cabe salientar que as barreiras impermeabilizantes podem sofrer solicitações devido à acomodação e peso próprio dos resíduos, cargas pontuais e mudanças de temperatura. Desta forma, como consequência de tais solicitações e da disposição dessas barreiras sobre os taludes, poderá ocorrer presença de interfaces apresentando baixa resistência ao cisalhamento, acarretando o aparecimento de uma potencial superfície de deslizamento ou ruptura. Assim, a determinação dos parâmetros de resistência ao cisalhamento torna-se imprescindível para a verificação da estabilidade dessas barreiras impermeáveis.

Segundo Pinto (2000), as argilas se diferenciam das areias pela sua baixa condutividade hidráulica, razão pela qual adquire importância o conhecimento de sua resistência, tanto em termos de carregamento drenado, como de carregamento nãodrenado.

De acordo com Das (2007), o ensaio de compressão triaxial é um dos mais confiáveis métodos disponíveis para a determinação dos parâmetros da resistência ao cisalhamento. Um diagrama do layout do ensaio triaxial é mostrado na Figura 3.9. 


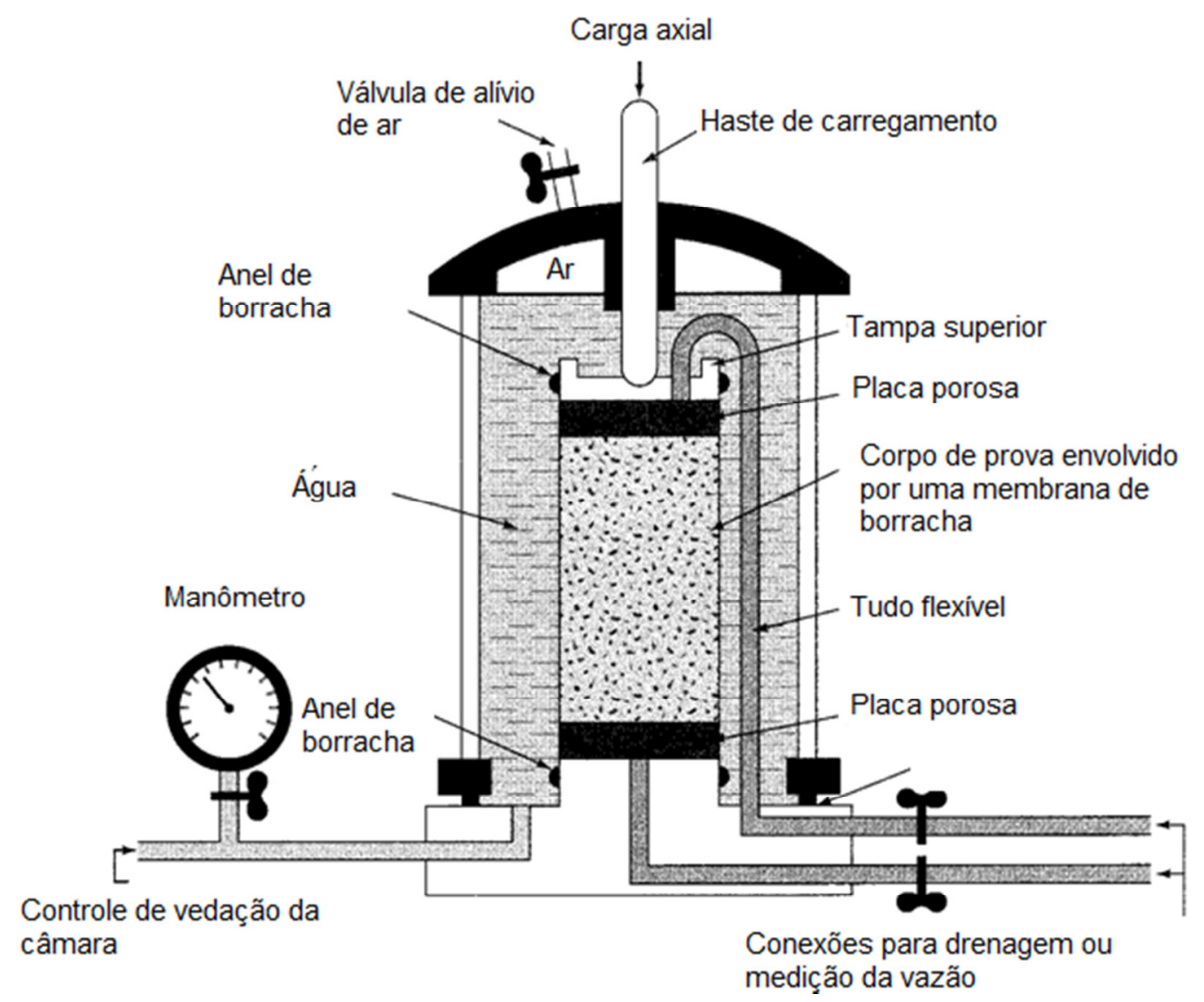

Figura 3.9: Diagrama do equipamento triaxial (adaptado de DAS, 2007).

O corpo de prova é envolvido por uma fina membrana de borracha e colocado dentro de uma câmara cilíndrica que é normalmente preenchida com água ou glicerina. $\bigcirc$ corpo de prova é submetido a uma pressão de confinamento por compressão do fluído da câmara. Para provocar a ruptura por cisalhamento do corpo de prova, deve-se aplicar uma tensão axial por meio de uma haste de carregamento vertical. Essa tensão pode ser aplicada em uma das seguintes formas:

- Aplicação de pesos ou pressão hidráulica em incrementos iguais até que o corpo de prova rompa. Neste caso, a deformação axial do corpo de prova resultante da carga aplicada por meio da haste é medida por meio de um extensômetro;

- Aplicação de deformação axial a velocidade constante por meio de uma prensa de carregamento mecânico ou hidráulico. Este é um ensaio de deformação controlada. 
A carga axial aplicada pela haste de carregamento correspondente a uma dada deformação axial é medida por anel dinanométrico ou célula de carga fixada à haste. As conexões para medir a drenagem interna ou externa ao corpo de prova ou para medir a pressão na água intersticial (de acordo com as condições de ensaio) também são fornecidas. Os três tipos padrão de ensaios triaxiais são: i) ensaio adensado drenado ou ensaio drenado (ensaio CD); ii) ensaio adensado não-drenado (ensaio CU); iii) ensaio nãoadensado não-drenado ou ensaio não-drenado (ensaio UU). A definição de cada um desses tipos de ensaios está apresentada a seguir, de acordo com Craig (2004).

- Ensaio não-adensado e não-drenado (UU): a amostra é submetida a uma pressão de confinamento $\left(\sigma_{3}\right)$ e imediatamente a tensão desviatória $\left(\sigma_{1}-\sigma_{3}\right)$ é aplicada. Durante essas fases não é permitida a drenagem do corpo de prova;

- Ensaio adensado e não-drenado (CU): a drenagem do corpo de prova é permitida durante a aplicação da tensão confinante $\left(\sigma_{3}\right)$, até que o adensamento se processe completamente. Em seguida, a tensão desviatória é aplicada sem que se permita a drenagem. São efetuadas medidas de pressão neutra durante a fase não-drenada do ensaio.

- Ensaio adensado e drenado (CD): é permitida a drenagem do corpo de prova em ambas as etapas. Inicialmente, ocorre a aplicação da tensão de confinamento e, em seguida, aplica-se a tensão desviatória, a qual é aumentada a uma razão tal que a pressão neutra seja mantida igual a zero.

A resistência não-drenada é utilizada quando as pressões neutras ocasionadas por um carregamento, não são dissipadas em um intervalo de tempo condizente com aquele que se levou para aplicar o carregamento. Esse tipo de situação é típico de aplicação em argilas devido à baixa condutividade hidráulica que tais materiais apresentam. A resistência não-drenada pode ser obtida em laboratório sob duas formas principais de ensaios: i) ensaios consolidados e não-drenado (CU); ii) ensaios não-drenados (UU).

Lukiantchuki (2007) afirma que o ensaio tipo adensado não-drenado (CU) é o tipo que melhor se aplica à análise da estabilidade de barreiras impermeabilizantes. Este ensaio representa a situação na qual o maciço apresenta-se em equilíbrio com as tensões 
aplicadas e, em seguida, ao ocorrer uma solicitação rápida, sem a possibilidade de dissipação de novas tensões neutras gerada, ocorre a ruptura. Essa situação pode ser comparada ao carregamento de uma barreira impermeabilizante, onde durante 0 lançamento e alteamento do aterro de resíduos dentro da célula de disposição, é permitida a dissipação de pressões neutras geradas. No momento no qual se atinge uma altura ou solicitação crítica, gera-se uma tensão que promove a ruptura da barreira de forma instantânea.

\subsection{Antecedentes da pesquisa}

O aterro sanitário de Rio Grande (RS) passou a ser alvo de pesquisas quando Souza (2007) realizou o projeto de graduação intitulado "Estudo do emprego de misturas solobentonita na construção de liners para impermeabilização de aterros sanitários - estudo de caso: aterro sanitário de Rio Grande". O autor estudou o solo local do aterro e o de uma jazida localizada em Domingos Petroline, interior do município de Rio Grande. Os teores de bentonita avaliados foram 2 e 4\%, com e sem cura. Os ensaios foram realizados em permeâmetro de parede rígida e parede flexível. Nesse trabalho não foram obtidos valores de condutividade hidráulica aceitáveis de acordo com as normas ambientais.

Souza (2007) chegou às seguintes conclusões:

- Os ensaios em permeâmetro de parede flexível resultam em valores de condutividade hidráulica menores quando comparados com os de parede rígida;

- Os teores de 2 e $4 \%$ de bentonita são insuficientes para reduzir a condutividade hidráulica do solo local do aterro a patamares indicados pelas legislações ambientais;

- Merece ser investigada a utilização de areia local do aterro com a adição de teores mais elevados de bentonita.

Camargo et al(2008) deram continuidade ao estudo de Souza (2007), ensaiando solos de empréstimo da região, em permeâmetro de parede flexível a carga constante. Concluiu-se que o solo identificado como MBAR foi o único que atendeu as exigências 
legais. Desta forma, consolidou-se a posição da "argila vermelha", oriunda do solo natural de cobertura das saibreiras do Capão do Leão como único material da região que, na condição natural, atende os requisitos dos órgãos ambientais para construção de liners. Entretanto, esta jazida está distante mais de 70 quilômetros do local do aterro, o que pode inviabilizar sua utilização devido ao aumento do custo de transporte.

Camargo (2009) continuou os estudos de Souza (2007) e Camargo et al (2008) avaliando o comportamento da condutividade hidráulica do solo local do aterro, com teores mais elevados de bentonita e comparando os custos com outras alternativas tecnicamente viáveis. Com os ensaios em permeâmetro de parede flexível, o autor constatou uma redução significativa na condutividade hidráulica (de $10^{-6}$ a $10^{-10} \mathrm{~m} / \mathrm{s}$ ). Entretanto, somente a mistura com $14 \%$ de bentonita mostrou-se apta a ser utilizada como liner de aterro sanitário. A avaliação econômica mostrou que o uso de $G C L$ era o mais econômico. A utilização da mistura do solo local com 14\% de bentonita mostrou-se 5,6 vezes mais onerosa que o uso de GCL e a utilização do solo MBAR, 1,43 vezes.

Silva et al (2010) avaliaram a condutividade hidráulica do solo local do aterro, utilizando a Energia do Proctor Intermediário para a compactação. Os trabalhos até então realizados utilizaram a Energia do Proctor Normal. Utilizando-se uma maior energia de compactação, o solo local precisou de apenas $4 \%$ de bentonita para tornar-se apto a ser utilizado como liner de aterros sanitários.

Silva (2011) avaliou a condutividade hidráulica de um solo arenoso fino de comportamento laterítico da região costeira sul do Estado do Rio Grande do Sul, denominado ARMAR, no condição pura e misturado à bentonita sódico comercial, nos teores de 2, 4, 6, 8, 10, 12 e 14\%, compactados na Energia do Proctor Intermediário. Estudo semelhante foi feito para uma mistura composta do solo ARMAR e bentonita do Bañado de Medina (Uruguai), exclusivamente no teor de $4 \%$. O trabalho apresenta também as caracterizações geotécnicas, química e pela Metodologia MCT dos materiais, assim como as propriedades do solo compactado através dos ensaios de contração, mini-CBR e expansão. Os resultados indicam que a adição de bentonita no teor de $4 \%$ habilita a utilização do solo estudado em barreiras minerais de aterros sanitários. 


\section{Capítulo 4 Materiais e métodos}

Este capítulo tem como objetivo descrever os materiais utilizados na pesquisa, o método utilizado na preparação e confecção dos corpos de prova e os métodos utilizados para a realização dos ensaios.

\subsection{Materiais}

\subsubsection{Solo}

Algumas regiões da costa brasileira, dentre as quais o litoral sul do Rio Grande do Sul, apresentam deficiência de materiais considerados nobres em obras de terra, tais como agregados pétreos e solos residuais (BASTOS et al. 2008). Desde 1993, o Laboratório de Geotecnia da FURG - Universidade Federal do Rio Grande vem realizando estudos que visam o reconhecimento e caracterização de solos considerados alternativos para este tipo de emprego.

Com a realização desses estudos, pretendeu-se verificar a possibilidade de se utilizar um solo encontrado no horizonte de evolução pedogenética de uma das barreiras litorâneas que formam a Planície Costeira Sul do Rio Grande do Sul, de idade pleistocênica, denominada Barreira Litorânea II (VILLWOCK,1984). Esse solo tem sido explorado de forma incipiente para pequenas obras de terra. Entretanto, suas peculiares características físicas e morfológicas, assemelhadas a solos arenosos finos lateríticos da região sudeste do país, justificaram aprofundado estudo das propriedades geotécnicas deste solo na condição compactada (BASTOS et al. 2008),

Devido aos motivos acima descritos, esse foi o solo escolhido para a realização da presente pesquisa. O solo estudado pertence ao horizonte pedogenético B de perfis de Argilossolos Vermelho-Amarelos, formados nos terrenos sedimentares da Barreira Litorânea II (BASTOS et al., 2008). A Figura 4.1 ilustra a ocorrência do solo no litoral sul do Rio Grande do Sul, bem como indica a jazida estudada. 


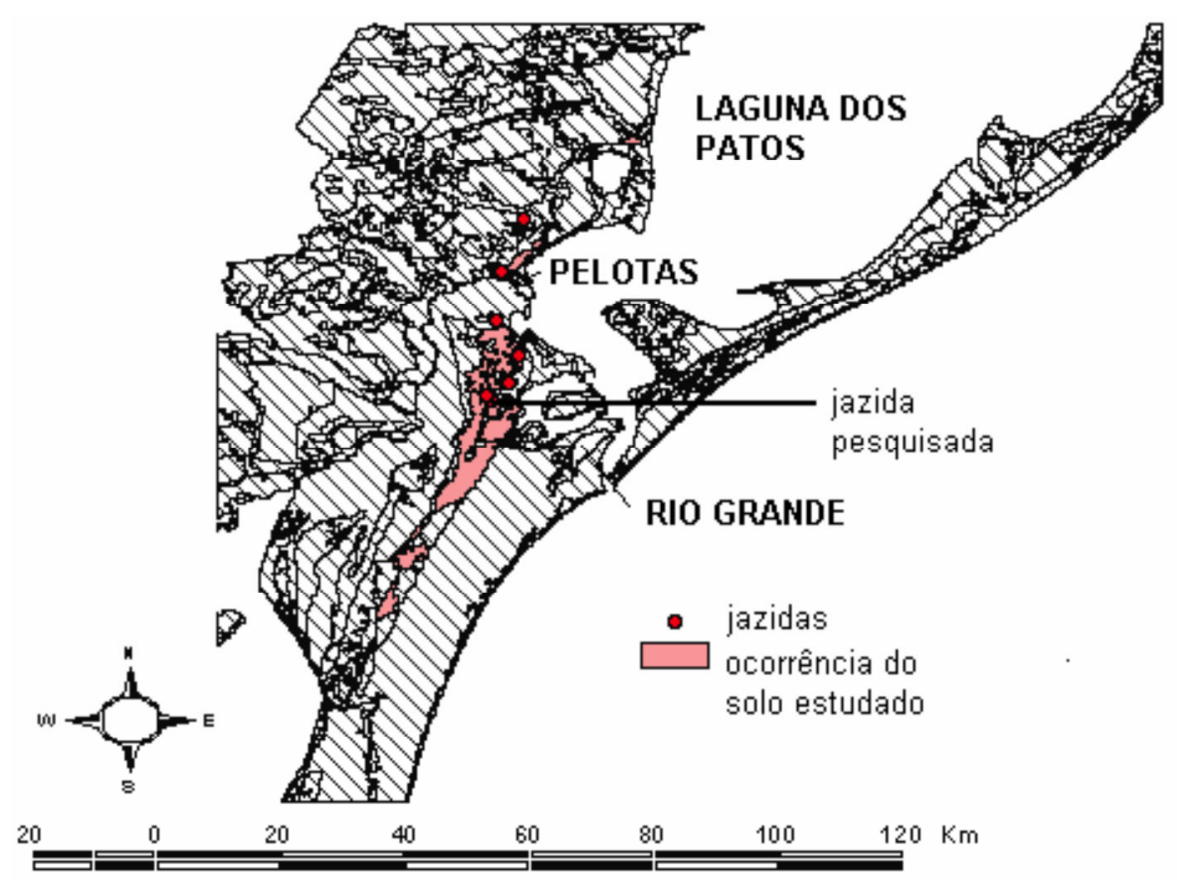

Figura 4.1: Ocorrência do solo estudado no litoral do Estado do Rio Grande do Sul e localização da jazida da qual o solo foi obtido (BASTOS et al., 1998).

A Barreira Litorânea II constitui um dos sistemas deposicionais do tipo "lagunabarreira" formadores da Planície Costeira, conforme ilustra a Figura 4.2. A ocorrência desta barreira está relacionada ao segundo evento transgressivo-regressivo do mar no Pleistoceno, com idade aproximada de $325 \mathrm{ka}$. Trata-se do sistema ilhas-barreira responsável pelo primeiro isolamento da Lagoa Mirim. Os sedimentos são compostos por areias quartzofeldspáticas, castanho-amareladas, bem-arredondas, envoltas em uma matriz síltico-argilosa de natureza diagenética. Os processos pedogenéticos atuais e pretéritos afetaram profundamente estes sedimentos, o que destruiu estruturas sedimentares primárias. Os processos pedogenéticos atuantes sobre este pacote de sedimentos arenosos, em particular a translocação de elementos no perfil e a consequente acumulação de argila e óxidos de ferro e alumínio no horizonte B, determinaram a formação de Argilossolos VermelhoAmarelos distróficos arênicos, identificados como pertencentes a unidade de mapeamento de solos Tuia (EMBRAPA, 2006). 
W

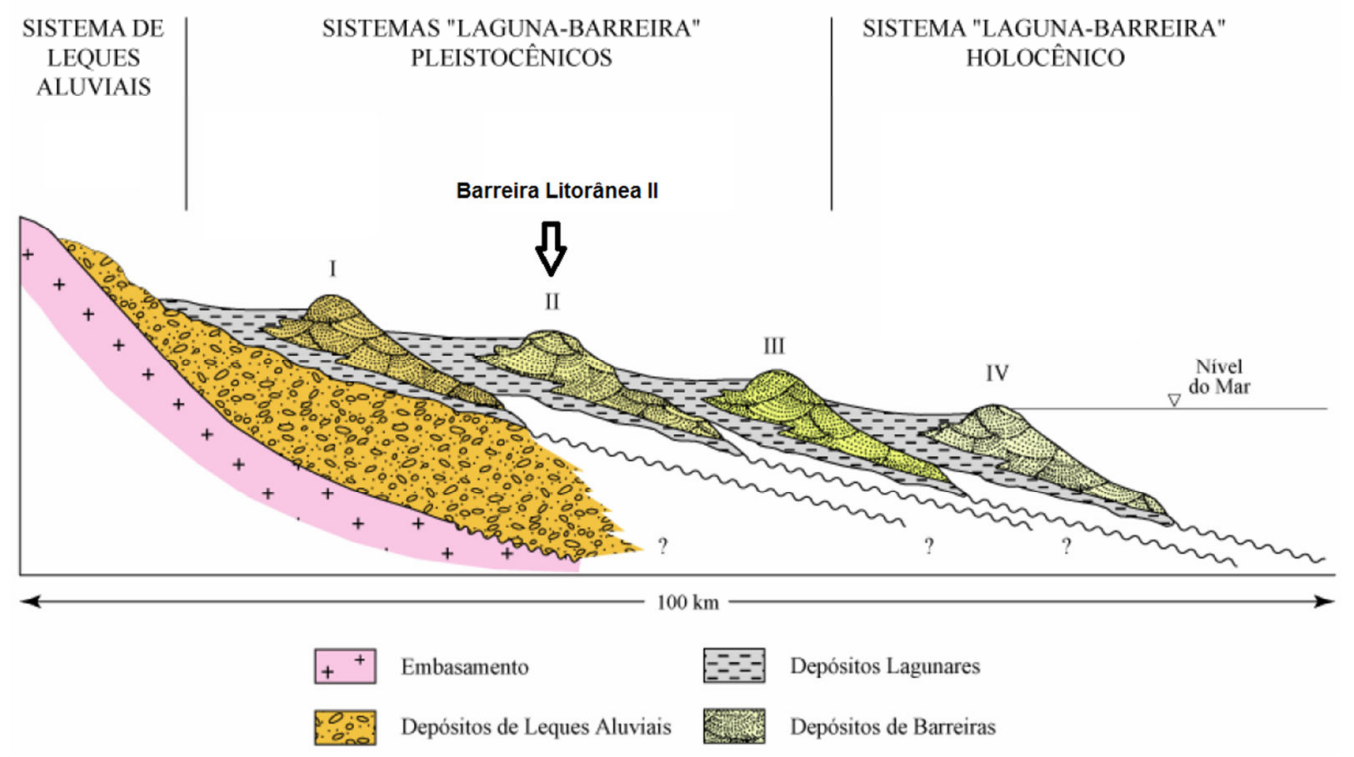

Figura 4.2: Perfil esquemático (W-E) transversal aos sistemas deposicionais da Placície Costeira Sul do Estado do Rio Grande do Sul (modificado de VILLWOCK E TOMAZELLI, 1995)

A jazida estudada localiza-se às margens da BR-392, no trecho Pelotas-Rio Grande, na localidade de Domingos Petroline, município de Rio Grande/RS. Seguindo a nomenclatura do Laboratório de Geotecnia da FURG, tanto esse solo como a jazida são identificados como solo ARMAR.

Foram coletados $500 \mathrm{~kg}$ desse solo na jazida e acondicionados em três caixas de madeirite, conforme ilustrado na Figura 4.3. Desta forma, o material pode ser transportado de Rio Grande a São Carlos. Atualmente, jazidas deste solo são exploradas para as obras de duplicação da BR-392, que liga Pelotas a Rio Grande. Para a realização dos ensaios, o solo foi secado artificialmente. 


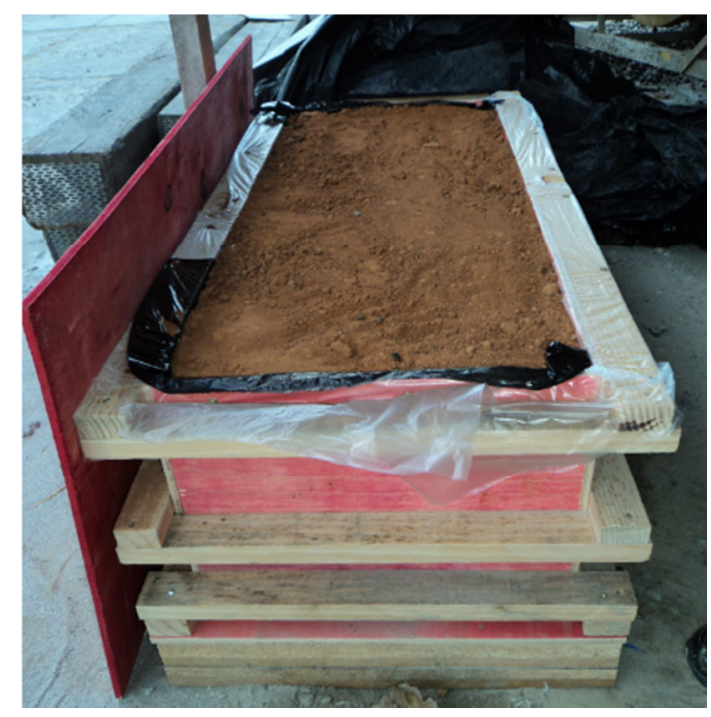

Figura 4.3: Caixa de madeirite na qual foi transportada a amostra

\subsubsection{Bentonita}

A bentonita utilizada para a realização dos ensaios é comercialmente denominada de Permagel, tendo sido fornecida pela empresa Bentonit União Nordeste S. A. A Tabela 4.1 apresenta a composição química da bentonita e a Tabela 4.2 apresenta algumas propriedades gerais da mesma.

Tabela 4.1: Composição química da bentonita Permagel (Fonte: catálogo do fabricante)

\begin{tabular}{c|c}
\hline Composição química & $\%$ \\
\hline Anidro silícico & 60,2 \\
Óxido de alumínio & 18,5 \\
Óxido férrico & 7,2 \\
Óxido de magnésio & 2,0 \\
Óxido de cálcio & 2,4 \\
Óxido de titânio & 0,9 \\
Óxido de potássio & 0,53 \\
\hline
\end{tabular}

Tabela 4.2: Propriedades da bentonita Permagel (Fonte: catálogo do fabricante)

\begin{tabular}{c|c}
\hline Propriedade & \\
\hline Peso específico dos sólidos $\left(\mathrm{kN} / \mathrm{m}^{3}\right)$ & $28-30$ \\
Limite de liquidez $(\%)$ & $450-490$ \\
Limite de plasticidade $(\%)$ & $40-65$ \\
Peso específico seco $\left(\mathrm{kN} / \mathrm{m}^{3}\right)$ & 9,6 \\
Teor de umidade ótimo $(\%)$ & 50 \\
Umidade natural & $17-19$ \\
Condutividade hidráulica $(\mathrm{m} / \mathrm{s})$ & $1.10-10$ \\
$\mathrm{pH}-4.5 \%$ suspensão $(\%)$ & 9,5 \\
\hline
\end{tabular}




\subsubsection{Misturas solo-bentonita}

Foram utilizadas misturas de solo-bentonita nos teores de 2,4 e $6 \%$, as quais são denominadas neste trabalho por S02, S04 e S06, respectivamente. O solo natural, ou seja, sem o acréscimo do aditivo é denominado S00. Cabe ressaltar que as proporções de solo e bentonita foram calculadas em termos de massa seca dos materiais.

A preparação das referidas misturas foi realizada adotando os seguintes procedimentos:

- Homogeneização do solo sem acréscimo de aditivo com o auxílio da peneira de $2 \mathrm{~mm}$;

- Adição da bentonita no teor desejado, seguido pela homogeneização manual da mistura;

- Adição, na quantidade necessária, da água, seguida pela completa mistura dos materiais;

- Acondicionamento da mistura em saco plásticos hermeticamente fechados e deixada em repouso por um período mínimo de 3 dias, com o intuito de se atingir a completa homogeneização do material.

\subsection{Métodos}

A seguir são apresentados os métodos de ensaio e demais procedimentos empregados durante o programa experimental. Para os ensaios que foram realizados baseando-se em procedimentos propostos em normas técnicas, será feita referência à mesma. No caso de modificação de algum procedimento descrito em norma ou na ausência de norma técnica referente ao assunto abordado, será realizada uma descrição mais detalhada do método adotado. 


\subsubsection{Ensaios de caracterização}

\subsubsection{Caracterização do solo e das misturas solo-bentonita}

A caracterização geotécnica do solo e das misturas solo-bentonita foi realizada de acordo com os ensaios recomendados pela Associação Brasileira de Normas Técnicas (ABNT): granulometria conjunta (NBR 7181/84), massa específica dos sólidos (NBR 6508/84), limite de liquidez (NBR 6459/84), limite de plasticidade (NBR 7180/84) e ensaio de compactação (NBR 7182/86).

\subsubsection{Ensaios de caracterização da bentonita}

O ensaio de granulometria conjunta foi realizado conforme recomendações da NBR 7181/84, com as seguintes modificações:

1) Ao invés de $70 \mathrm{~g}$ de material, foram utilizados $25 \mathrm{~g}$;

2) Para garantir a completa hidratação do material, o mesmo foi deixado em repouso durante uma semana em uma solução de $125 \mathrm{ml}$ de hexametafosfato de sódio para a sua completa hidratação. A concentração do hexametafosfato de sódio é de $45,7 \mathrm{~g}$ do sal para 1.000 cm³ de solução em água destilada.

O ensaio para determinação da massa específica dos grãos seguiu as recomendações da NBR 6508/84, com as seguintes modificações:

1) Foram utilizados $15 \mathrm{~g}$ do material, ao invés dos $50 \mathrm{~g}$, conforme recomendado pela norma;

2) O tempo de repouso da amostra em água destilada foi de 7 dias.

O prolongamento do tempo de repouso do material foi necessário para que fosse possível alcançar a sua completa hidratação. A diminuição da quantidade de material utilizado foi necessária devido à alta expansibilidade da bentonita. 


\subsubsection{Ensaios em equipamento triaxial}

\subsubsection{Preparação dos corpos de prova}

Os corpos de prova utilizados nos ensaios triaxiais foram compactados dinamicamente, na energia do Proctor Intermediário. As dimensões consideradas aceitáveis foram de $50 \pm 1 \mathrm{~mm}$ de diâmetro e $125 \pm 1 \mathrm{~mm}$ de altura, de forma a atender a relação altura-diâmetro prescrita pela Norma ASTM D 4767/95 (H=2,0 a 2,5 D). Os parâmetros de compactação foram obtidos através de procedimento de compactação do ensaio de Proctor Intermediário.

\subsubsection{Aquisição de dados}

Os ensaios triaxiais foram realizados utilizando um novo sistema de aquisição de dados. Esse novo sistema de aquisição de dados é da marca HBM, modelo MX 410 (Figura 4.5). Este sistema de aquisição de dados é portátil e possui quatro canais. Apesar desse sistema ser indicado para analisar eventos dinâmicos, foi utilizado na realização dos ensaios triaxiais, por se extremamente versátil. Como software de interface foi utilizado o catmanEasy versão 3.0. Este programa permite o processamento e o registro gráfico dos dados.

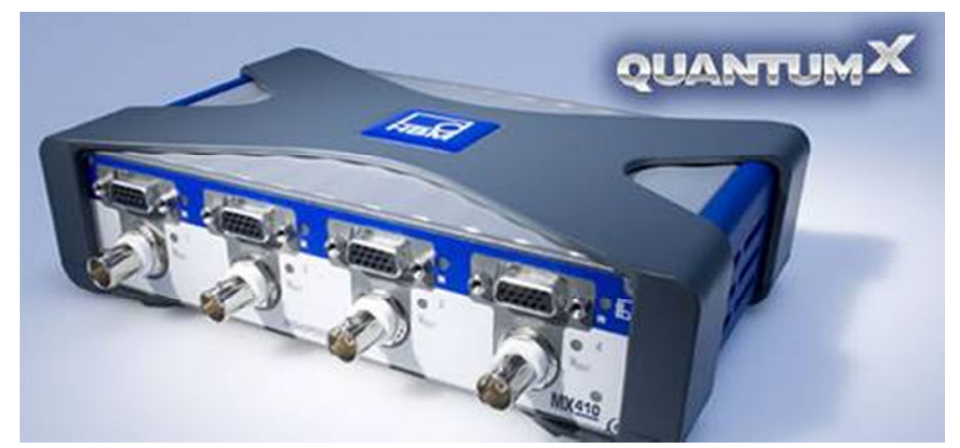

Figura 4.4: Sistema de aquisição de dados HBM, modelo MX410 (disponível em www.hbm.com em $02 / 07 / 2011)$

Os quatro canais de leitura do equipamento foram assim distribuídos:

1) Pressão neutra: através de um transdutor de pressão;

2) Força: através de uma célula de carga; 
3) Deslocamento: através de um transdutor de deslocamento;

4) Variador de volume: através de um transdutor de deslocamento acoplado a um variador de volume.

A partir dos resultados das leituras destes canais, são criados quatro novos canais virtuais, que fornecem:

5) Deformação axial:

$$
\varepsilon=\frac{\text { deslocamen to }}{h_{0}} \times 100 \%
$$

onde: $\varepsilon=$ deformação axial; deslocamento = leitura do canal $3 ; h_{0}=$ altura inicial do corpo de prova.

6) Deformação volumétrica:

$$
\varepsilon_{v}=\frac{V}{V_{0}} \times 100 \%
$$

onde: $\varepsilon_{\vee}=$ deformação volumétrica; $V=$ leitura do canal $4 ; V_{0}=$ volume inicial do corpo de prova.

7) Área corrigida:

$$
A_{c}=A_{0} \times\left(\frac{1-\frac{\varepsilon_{v}}{100}}{1-\frac{\varepsilon_{a}}{100}}\right)
$$

onde: $A_{c}=$ área corrigida do corpo de prova; $A_{0}=$ área inicial do corpo do prova; $\varepsilon_{\mathrm{v}}=$ deformação volumétrica $\varepsilon_{a}=$ deformação axial (Canal 05).

8) Tensão desviatória $\left(\sigma_{1}-\sigma_{3}\right)$.

$$
\Delta \sigma=\frac{\Delta F}{A_{c}}
$$

onde: $\Delta \sigma=$ tensão desviatória; $\Delta F=$ variação de força; $A_{c}=$ área corrigida do corpo de prova. 


\subsubsection{Procedimentos de montagem}

A montagem do corpo de prova na câmara triaxial é realizada da seguinte maneira:

1) Imersão de um par de pedras porosas em água, para que sejam saturadas.

2) Realização do controle de qualidade das membranas, com o intuito de identificar possíveis furos nas mesmas. Este processo é realizado com o auxílio de um testador de membranas, conforme mostrado na Figura 4.6.

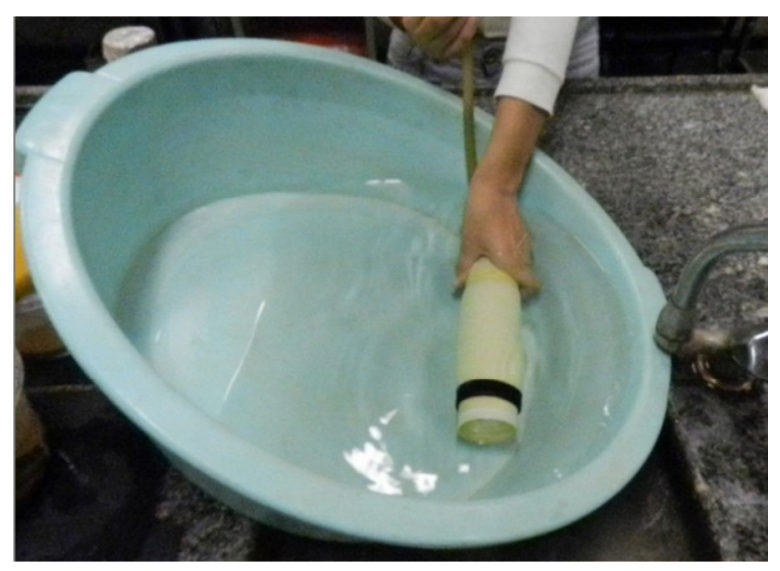

Figura 4.5: Controle de qualidade da membrana.

3) Limpeza do pedestal da câmara e lubrificação com gel siliconado.

4) Saturação das válvulas do pedestal da câmara triaxial, conforme mostra a Figura 4.7.

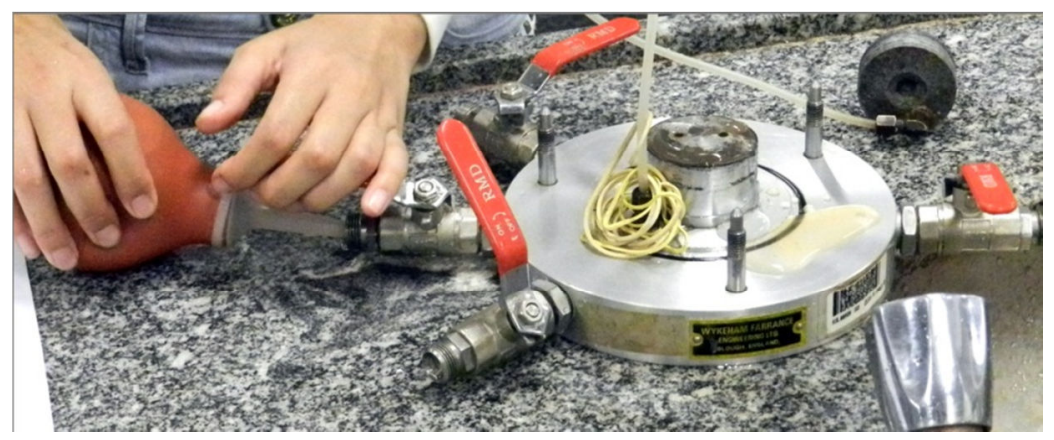

Figura 4.6: Saturação das válvulas do pedestal da câmara triaxial. 
5) Colocação da pedra porosa e papel filtro saturado. Após, coloca-se o corpo de prova, seguido por papel filtro saturado e pedra porosa, conforme ilustrado na Figura 4.8 .

6) As regiões inferior e superior do corpo de prova devem ser protegidas por duas membranas látex impermeáveis. Este procedimento garantirá a integridade da segunda camada de membrana que cobrirá todo o corpo de prova, conforme mostra a Figura 4.9.

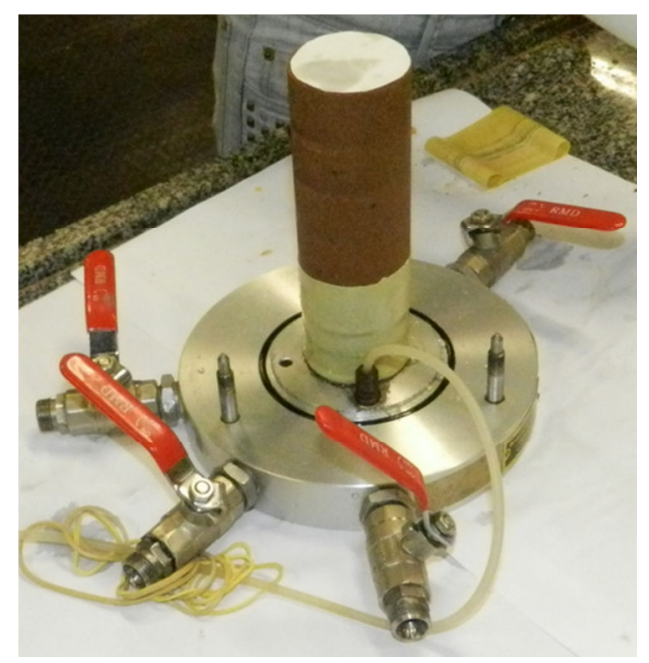

Figura 4.7: Colocação do corpo de prova no pedestal da câmara triaxial.

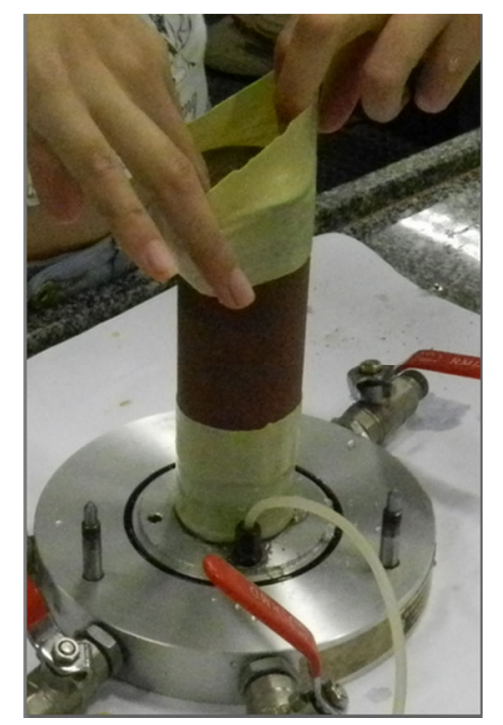

Figura 4.8: Colocação das membranas protetoras. 
7) Colocação de membrana látex fixada com anéis o'ring na base e elásticos de borracha no topo, conforme mostra a Figura 4.10.

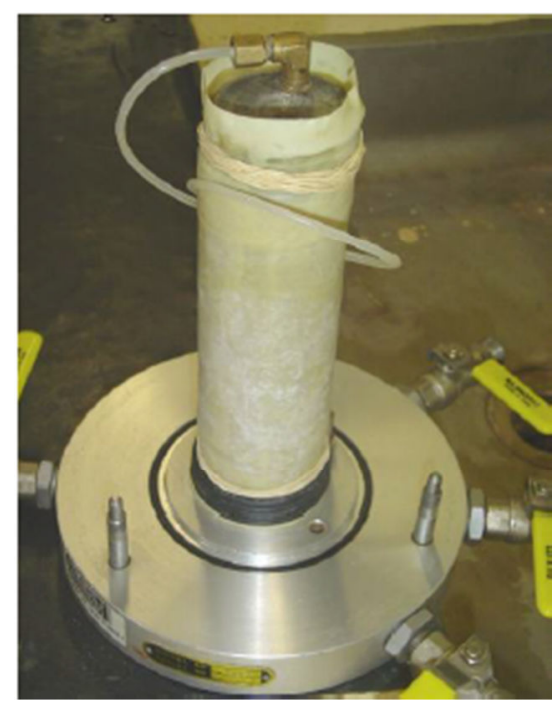

Figura 4.9: Corpo de prova protegido por membrana látex, fixada com anéis o'ring na base e elásticos de borracha no topo.

\subsubsection{Saturação dos corpos de prova}

Inicialmente percola-se água durante 24 horas no corpo de prova. Isto é realizado mantendo-se a pressão confinante em $50 \mathrm{kPa}$ e a contrapressão em $40 \mathrm{kPa}$. A partir deste estágio, tanto a pressão confinante, quanto a contrapressão são aumentadas gradualmente, em incrementos de $50 \mathrm{kPa}$.

As pressões são elevadas, segundo este procedimento, até atingir o estágio no qual a pressão confinante é igual a $600 \mathrm{kPa}$ e a contrapressão é $590 \mathrm{kPa}$. Após este último incremento o sistema é deixado em repouso por, no mínimo, 24 horas. Após esse período de tempo, a saturação do corpo de prova é verificada através do parâmetro B de Skempton.O parâmetro B de Skempton é definido através da Equação 4.5.

$$
B=\frac{\Delta u}{\Delta \sigma}
$$

onde: $\Delta \mathrm{u}=$ acréscimo de pressão neutra gerada; $\Delta \sigma=$ incremento de pressão confinante aplicado. 
A leitura do parâmetro $B$ é realizada aplicando-se um incremento de pressão confinante de $50 \mathrm{kPa}$. Assume-se que o corpo de prova está saturado quando o valor de $B$ foi superior a 0,9 .

\subsubsection{Condutividade hidráulica antes e após a fase de adensamento}

Depois de confirmada a saturação do corpo de prova, é iniciada a fase de determinação da condutividade hidráulica. Esta fase é realizada mantendo-se a pressão confinante igual a $600 \mathrm{kPa}$, a pressão na base $590 \mathrm{kPa}$ e a pressão no topo $585 \mathrm{kPa}$.

Analogamente, é determinada a condutividade hidráulica após a fase adensamento dos corpos de prova. Entretanto, as pressões de base e de topo são ajustadas de acordo com a pressão confinante utilizada no adensamento.

O gradiente hidráulico utilizado nesta pesquisa foi de, aproximadamente, 4 .

\subsubsection{Adensamento e cisalhamento dos corpos de prova}

Na presente pesquisa, os ensaios triaxiais realizados foram do tipo adensado e não drenado (CU) e com um único estágio de carregamento. Foram realizadas 4 séries de ensaio (SO0, S02, S04 e S06), com um mínimo de três corpos de prova, variando a tensão de confinamento aplicada. Como se estima que a tensão máxima que o solo estará submetido em campo será de $400 \mathrm{kPa}$, as tensões de confinamento adotadas foram de 100, 200 e $400 \mathrm{kPa}$. A velocidade da prensa triaxial adotada para a realização dos ensaios foi de $0,2 \mathrm{~mm} / \mathrm{min}$.

\subsubsection{Determinação dos parâmetros de resistência}

Os parâmetros de resistência foram determinados a partir da envoltória de resistência para as trajetórias de tensão no espaço $p$ - $q$. Essa envoltória é a reta que melhor se ajusta aos pontos correspondentes à máxima tensão de cisalhamento na ruptura. Por definição: 


$$
\begin{aligned}
& p=\frac{\sigma_{1}+\sigma_{3}}{2} \\
& q=\frac{\sigma_{1}-\sigma_{3}}{2} \\
& p^{\prime}=p-u \\
& q^{\prime}=q
\end{aligned}
$$

onde:

$\sigma_{3}=$ tensão de confinamento;

$\sigma_{l}=$ tensão axial;

$u=$ pressão neutra.

A reta correspondente à envoltória de resistência no espaço $p-q$, em termos de tensões totais, pode ser representada pela Equação 4.10.

$$
q=a+p \times \tan \alpha
$$

onde $a$ e $\alpha$ representam os parâmetros de resistência modificados. Da mesma forma, a reta correspondente à envoltória de resistência no espaço $p^{\prime}$ - $q^{\prime}$, em termos de tensões efetivas, pode ser representado pela Equação 4.11.

$$
q^{\prime}=a^{\prime}+p^{\prime} \times \tan \alpha^{\prime}
$$

Pode-se demonstrar que os parâmetros de resistência, em termos de tensões totais, correspondente à envoltória de Mohr-Coulomb são dados por:

$$
\begin{aligned}
& \phi=\sin ^{-1}(\tan \alpha) \\
& c=\frac{a}{\cos \phi}
\end{aligned}
$$

onde:

$c=$ coesão total

$\phi=$ ângulo de atrito

Em termos de tensões efetivas, os parâmetros de resistência, correspondentes à envoltória Mohr-Coulomb, são dados por: 
$\phi^{\prime}=\sin ^{-1}\left(\tan \alpha^{\prime}\right)$

$c^{\prime}=\frac{a^{\prime}}{\cos \phi^{\prime}}$

onde:

$c^{\prime}=$ coesão efetiva

$\phi^{\prime}=$ ângulo de atrito efetivo

Desta forma, as envoltórias totais e efetivas são representadas, respectivamente, por: $\tau=c+\sigma \times \tan \phi$

$\tau=c^{\prime}+\sigma^{\prime} \times \tan \phi^{\prime}$ 


\section{Capítulo 5 Resultados e análises}

No decorrer deste capítulo são apresentados os resultados e análises das informações obtidas durante o programa experimental desta pesquisa.

\subsection{Caracterização geotécnica}

A Tabela 5.1 apresenta os resultados dos ensaios de caracterização geotécnica obtidos para o solo natural, para as misturas solo-bentonita e para a bentonita.

Tabela 5.1: Resultados dos ensaios de caracterização geotécnica

\begin{tabular}{c|cccccc}
\hline & & S00 & S02 & S04 & S06 & Bentonita \\
\hline$\gamma_{\mathbf{s}}\left(\mathbf{k N} / \mathbf{m}^{3}\right)$ & & 26,3 & 26,5 & 26,6 & 26.7 & 28,3 \\
& $W_{L}(\%)$ & 32 & 42 & 45 & 48 & 458 \\
Limites de & $W_{P}(\%)$ & 16 & 16 & 16 & 17 & 55 \\
consistência & $I_{p}(\%)$ & 16 & 26 & 29 & 31 & 403 \\
& IA Skempton & 0,71 & 1,11 & 1,24 & 1,20 & 5,40 \\
Classificação & & SC & SC & SC & SC & --- \\
Unificada & & & & & & \\
\hline
\end{tabular}

Os dados da tabela acima mostram que a bentonita apresenta um índice de atividade coloidal de um solo ativo. Desta forma, fica confirmado o tipo de argilomineral expansivo (2:1) da bentonita sódica utilizada nesta pesquisa. O solo natural, segundo este mesmo critério, é classificado como inativo. Além disso, constata-se que com o acréscimo de bentonita, todas as misturas passaram a ser classificadas como um solo de atividade normal.

Constata-se também que com o acréscimo de bentonita ao solo, o peso específico dos grãos aumenta. Este crescimento era esperado uma vez que o peso específico dos grãos da bentonita é maior que o do solo natural (28,3 e $26,3 \mathrm{kN} / \mathrm{m}^{3}$, respectivamente). 
Além disso, constata-se que há um aumento do limite de liquidez com o acréscimo de bentonita. Sabe-se que este era um comportamento esperado uma vez que o acréscimo de finos ao solo tende a aumentar o limite de liquidez do mesmo. O limite de plasticidade manteve-se praticamente constante com o acréscimo de bentonita e, consequentemente, o índice de plasticidade das amostras apresentou um comportamento altamente influenciado pelo limite de liquidez.

A Tabela 5.2 apresenta os resultados de granulometria conjunta para o solo natural, para a bentonita e para as misturas solo-bentonita. A Figura 5.1 apresenta a curva granulométrica do solo natural e a Figura 5.2 apresenta a curva granulométrica da bentonita. As Figuras 5.3 a 5.5 apresentam as curvas granulométricas das misturas solobentonita.

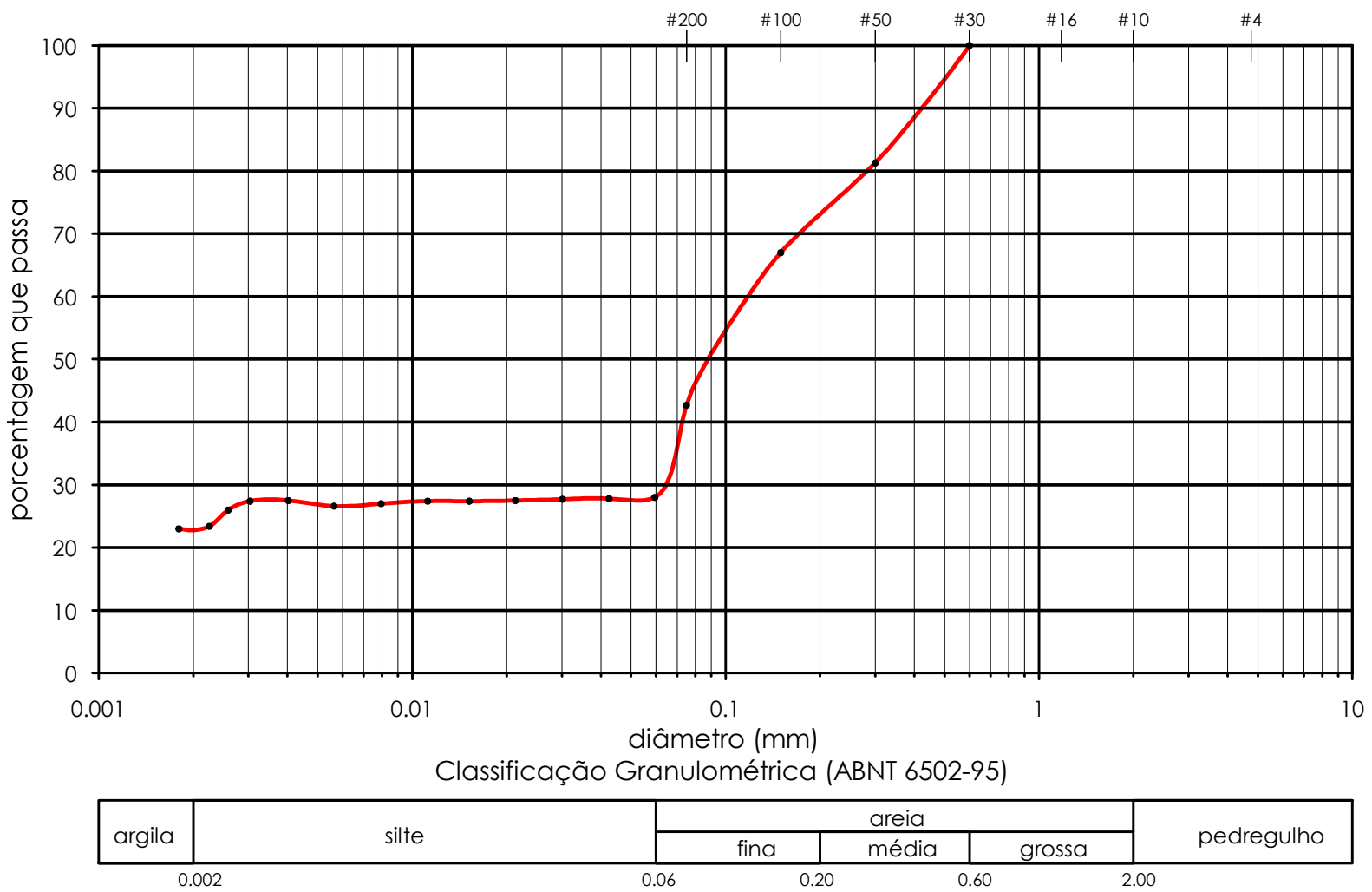

Figura 5.1: Curva granulométrica do solo natural 


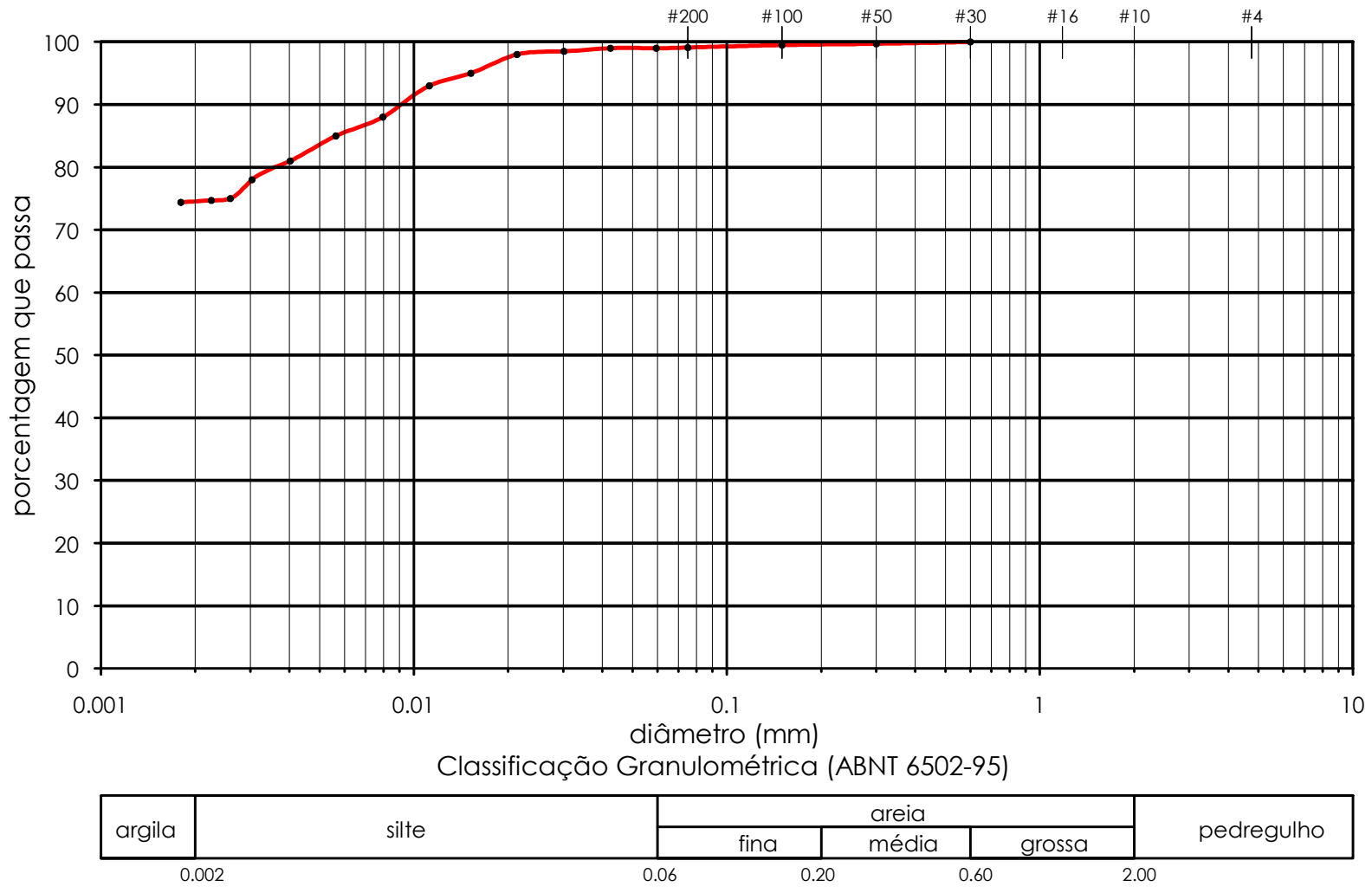

Figura 5.2: Curva granulométrica da bentonita

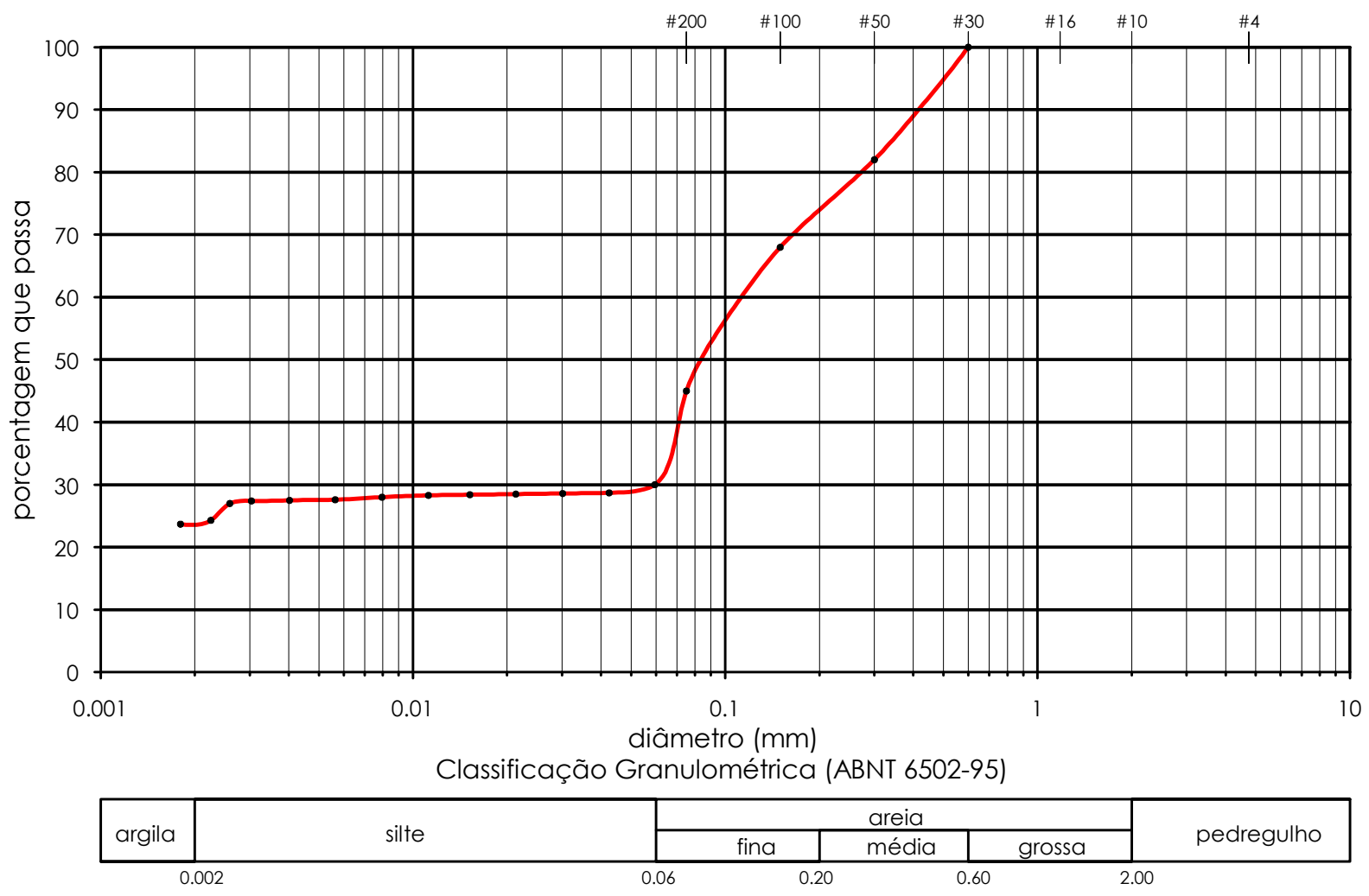

Figura 5.3: Curva granulométrica da mistura com $2 \%$ de bentonita 


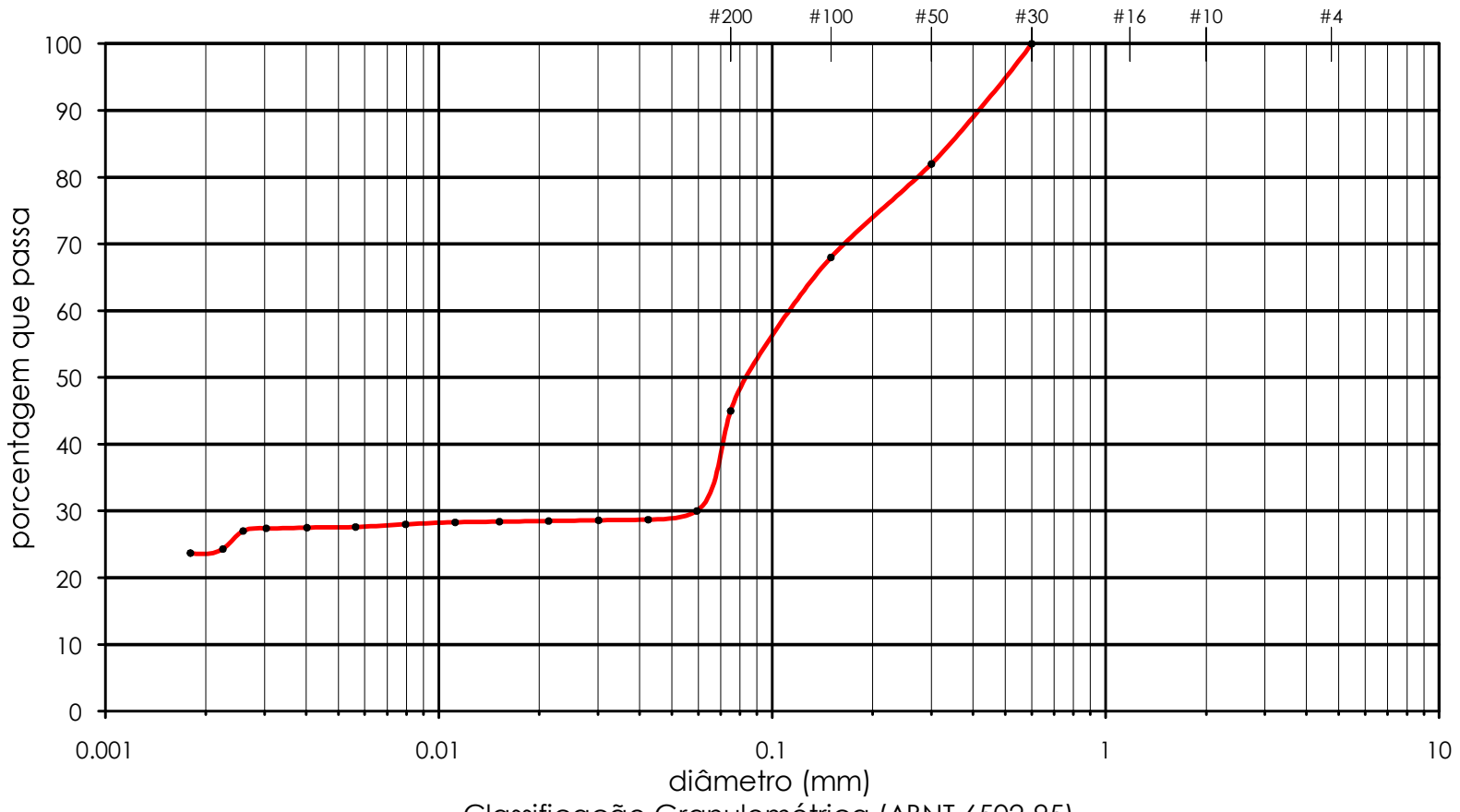

Classificação Granulométrica (ABNT 6502-95)

\begin{tabular}{|c|c|c|c|c|c|}
\hline \multirow{2}{*}{ argila } & \multirow{2}{*}{ silte } & \multicolumn{3}{|c|}{ areia } & \multirow{2}{*}{ pedregulho } \\
\hline & & fina & média & grossa & \\
\hline
\end{tabular}

Figura 5.4: Curva granulométrica da mistura com $4 \%$ de bentonita

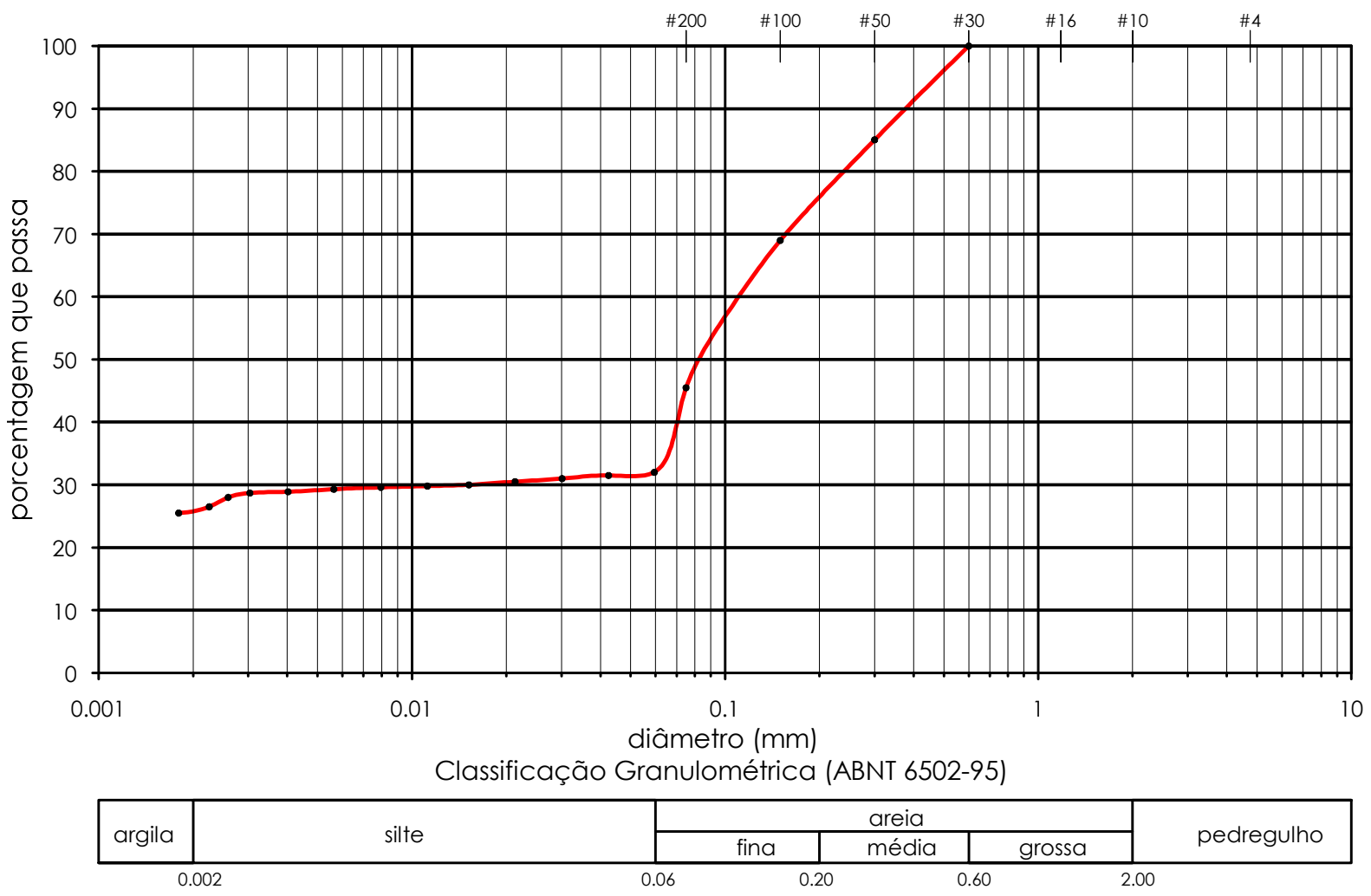

Figura 5.5: Curva granulométrica da mistura com $6 \%$ de bentonita 
Tabela 5.2: Resultados dos ensaios de granulometria conjunta

\begin{tabular}{c|ccccc}
\hline Fração granulométrica (\%) & S00 & S02 & S04 & S06 & Bentonita \\
\hline Argila & 24 & 24 & 24 & 25 & 75 \\
Silte & 4 & 6 & 6 & 6 & 24 \\
Areia Fina & 45 & 44 & 45 & 44 & 0,5 \\
Areia média & 27 & 26 & 25 & 25 & 0,5 \\
Areia grossa & 0 & 0 & 0 & 0 & 0 \\
\hline
\end{tabular}

Constata-se que a adição de bentonita não alterou significativamente a quantidade de argila das misturas. Este comportamento é semelhante ao encontrado por Morandini (2009). Esse autor acredita que parte da bentonita adicionada às misturas agregou e/ou floculou a grãos siltosos e arenosos. Como no presente trabalho observa-se uma diminuição das frações areia média e fina e um leve aumento das frações argila e silte, acredita-se que uma parte da bentonita tenha agregado e/ou floculado a fração silte.

As curvas obtidas nos ensaios de compactação estão apresentadas na Figura 5.6. Os parâmetros de compactação referentes a estas curvas estão mostrados na Tabela 5.3. A curva de saturação traçada é referente ao solo sem o acréscimo de aditivo.

Tabela 5.3: Parâmetros de compactação correspondentes ao Ensaio de Proctor Intermediário

\begin{tabular}{c|cc}
\hline & $\gamma d$ máx $\left(\mathrm{kN} / \mathrm{m}^{3}\right)$ & Wót (\%) \\
\hline S00 & 18,92 & 11,09 \\
S02 & 18,85 & 12,11 \\
S04 & 18,61 & 12,36 \\
S06 & 18,50 & 12,61 \\
\hline
\end{tabular}




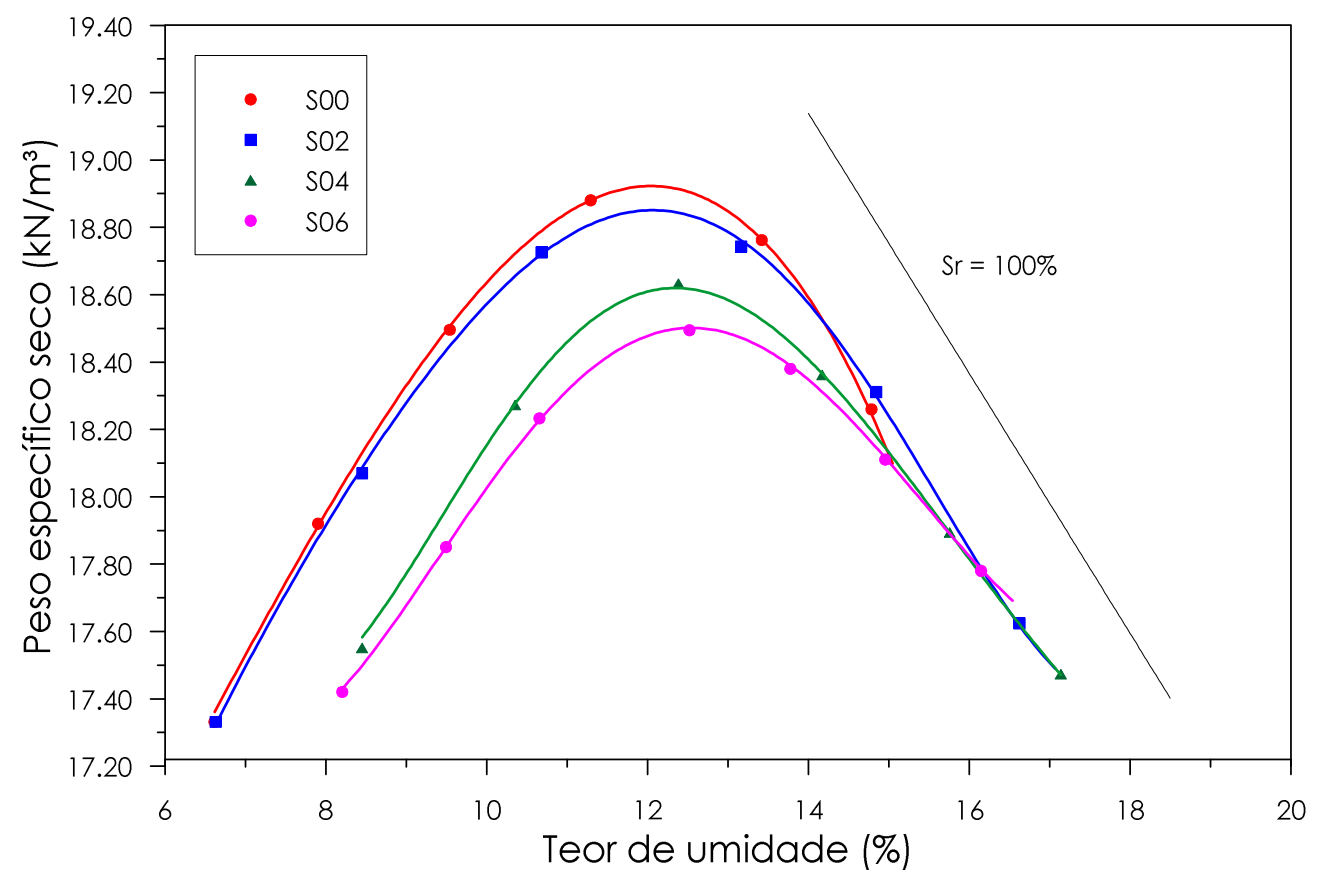

Figura 5.6: Curvas de compactação para o solo natural e para as misturas solo-bentonita

Através dos parâmetros de compactação obtidos pode-se observar que o solo natural e as misturas apresentaram comportamento compatível com o esperado. O teor de umidade ótimo aumentou com o acréscimo de bentonita. Isto ocorre, provavelmente, devido ao fenômeno de absorção de água pela bentonita durante o processo de homogeneização da mistura. Analogamente, constatou-se que o peso específico seco máximo diminuiu com o acréscimo de bentonita. Estima-se que este fenômeno ocorre, provavelmente, devido à textura do solo tornar-se gradualmente mais fina conforme o aumento no teor de bentonita.

\subsection{Ensaios em equipamento triaxial}

\subsubsection{Ensaios para a determinação da condutividade hidráulica antes da fase de adensamento}

As características de moldagem dos corpos de prova ensaiados e o parâmetro $B$ de Skempton encontram-se na Tabela 5.4. Onde $h_{0}$ é a altura inicial do corpo de prova, $D 0$ méd é o diâmetro inicial médio, $m$ é a massa, $w$ é o teor de umidade inicial, e é índice de vazios inicial, $G C$ é o grau de compactação e $B$ é o parâmetro de Skempton. 
Tabela 5.4: Características de moldagem dos corpos de prova

\begin{tabular}{|c|c|c|c|c|c|c|c|c|c|}
\hline & & $h_{\text {o méd }}(m)$ & Do méd $(m)$ & $m$ (g) & w (\%) & e & GC (\%) & Sr (\%) & B \\
\hline & CPOI & 0,1249 & 0,0505 & 533,01 & 0,1392 & 0,4055 & 98,90 & 90,28 & 0,99 \\
\hline \multirow[t]{3}{*}{ SOO } & СР02 & 0,1251 & 0,0505 & 532,85 & 0,1432 & 0,4131 & 98,37 & 91,15 & 0,99 \\
\hline & CPO3 & 0,1248 & 0,0505 & 536,55 & 0,1369 & 0,3923 & 99,84 & 91,77 & 0,98 \\
\hline & CPO1 & 0,1249 & 0,0505 & 534,96 & 0,1475 & 0,4213 & 98,91 & 92,78 & 0,96 \\
\hline \multirow[t]{3}{*}{ SO2 } & CP02 & 0,1249 & 0,0505 & 534,91 & 0,1469 & 0,4208 & 98,95 & 92,54 & 0,95 \\
\hline & CPO3 & 0,1250 & 0,0505 & 535,32 & 0,1452 & 0,4186 & 99,10 & 91,89 & 0,96 \\
\hline & CPO1 & 0,1251 & 0,0505 & 532,19 & 0,1533 & 0,4436 & 99,01 & 91,90 & 0,94 \\
\hline \multirow[t]{3}{*}{ SO4 } & СР02 & 0,1253 & 0,0504 & 532,90 & 0,1487 & 0,4326 & 99,77 & 91,45 & 0,94 \\
\hline & CP03 & 0,1253 & 0,0504 & 531,72 & 0,1516 & 0,4394 & 99,30 & 91,78 & 0,92 \\
\hline & CPOI & 0,1251 & 0,0504 & 529,07 & 0,1575 & 0,4571 & 99,05 & 91,97 & 0,91 \\
\hline \multirow[t]{2}{*}{ SO6 } & СРО2 & 0,1253 & 0,0504 & 530,50 & 0,1545 & 0,4518 & 99,41 & 91,32 & 0,91 \\
\hline & CPO4 & 0,1254 & 0,0504 & 529,61 & 0,1541 & 0,4549 & 99,20 & 90,45 & 0,92 \\
\hline
\end{tabular}

Os resultados dos ensaios de condutividade hidráulica do solo natural e das misturas solo-bentonita antes da fase de adensamento estão apresentados nas Figuras 5.7 a 5.10 . Para cada um dos teores de bentonita estudados foram realizados três ensaios. A condutividade hidráulica foi calculada em termos de variação de volume desde o tempo inicial. A Tabela 5.5 apresenta os resultados de condutividade hidráulica de estabilização de três corpos de prova por teor de bentonita avaliados, bem como as médias de tais valores. A Figura 5.11 apresenta a variação da condutividade hidráulica média, antes do adensamento, em função do teor de bentonita. 


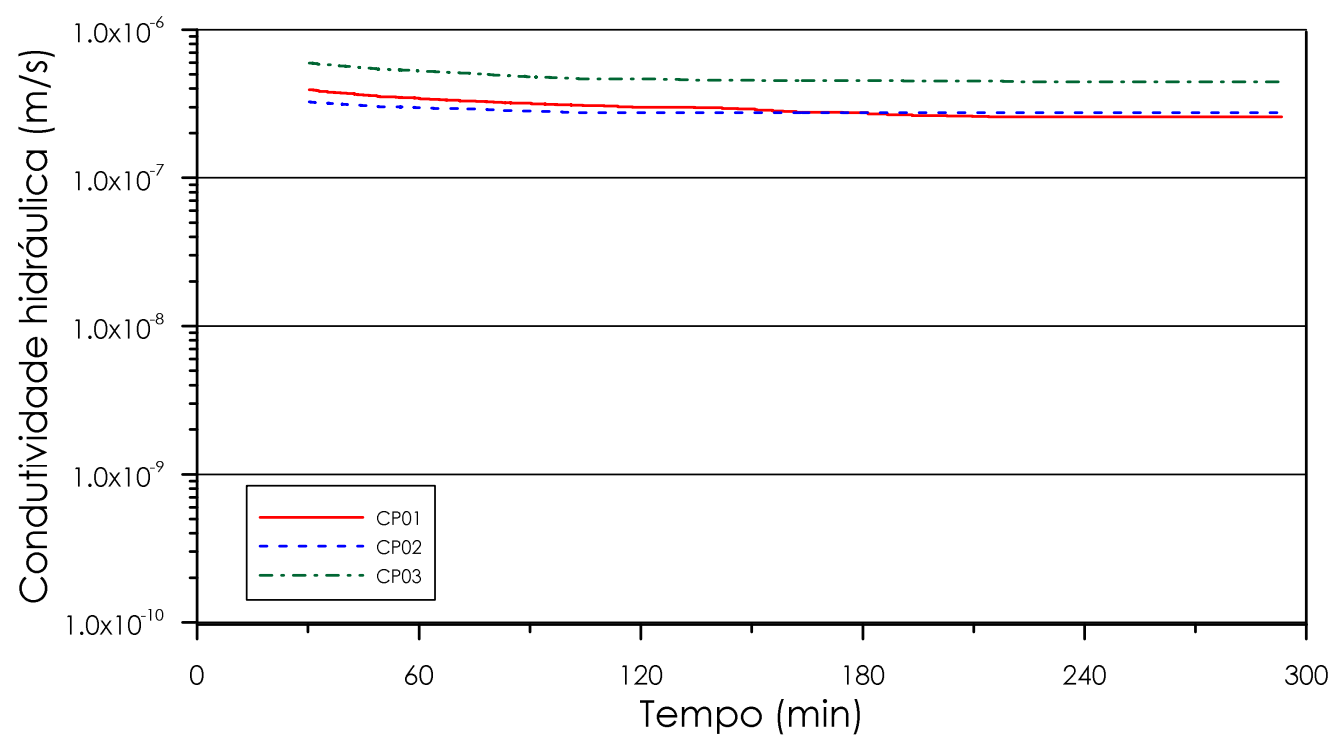

Figura 5.7: Condutividade hidráulica do solo natural

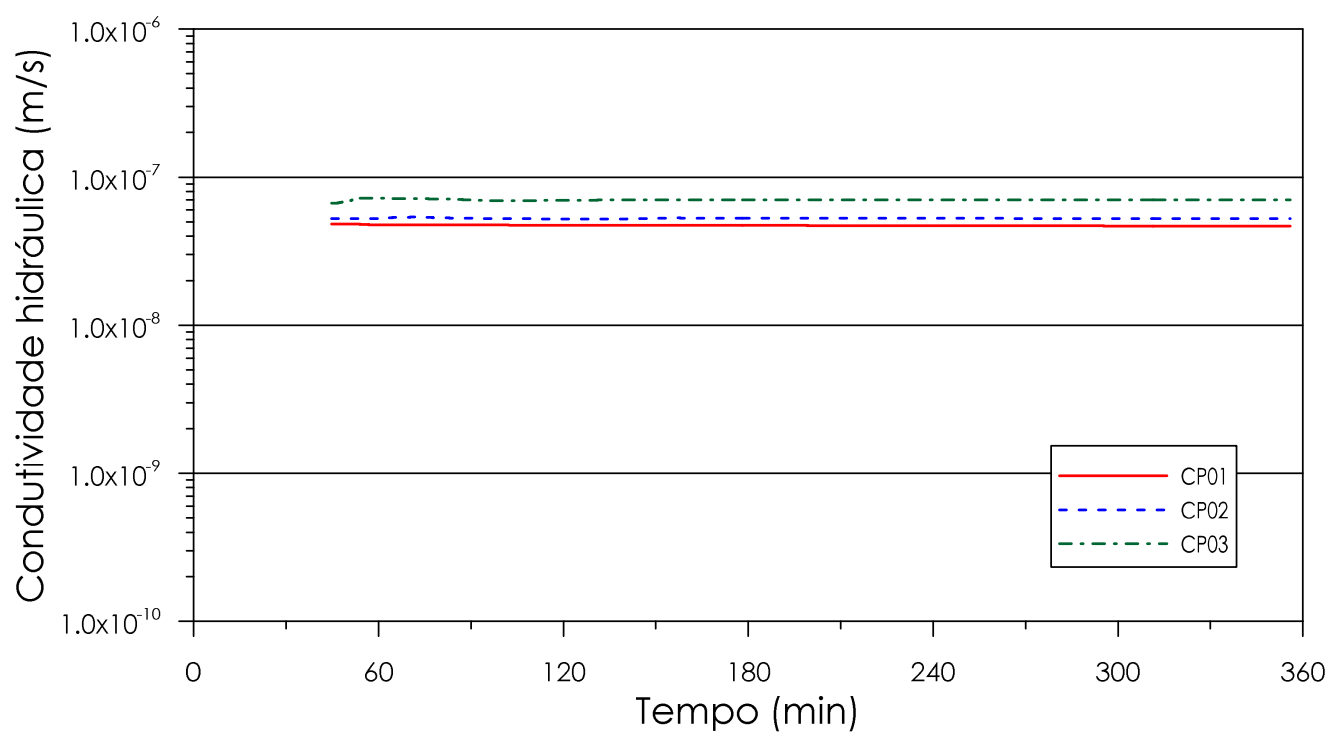

Figura 5.8: Condutividade hidráulica da mistura com $2 \%$ de bentonita 


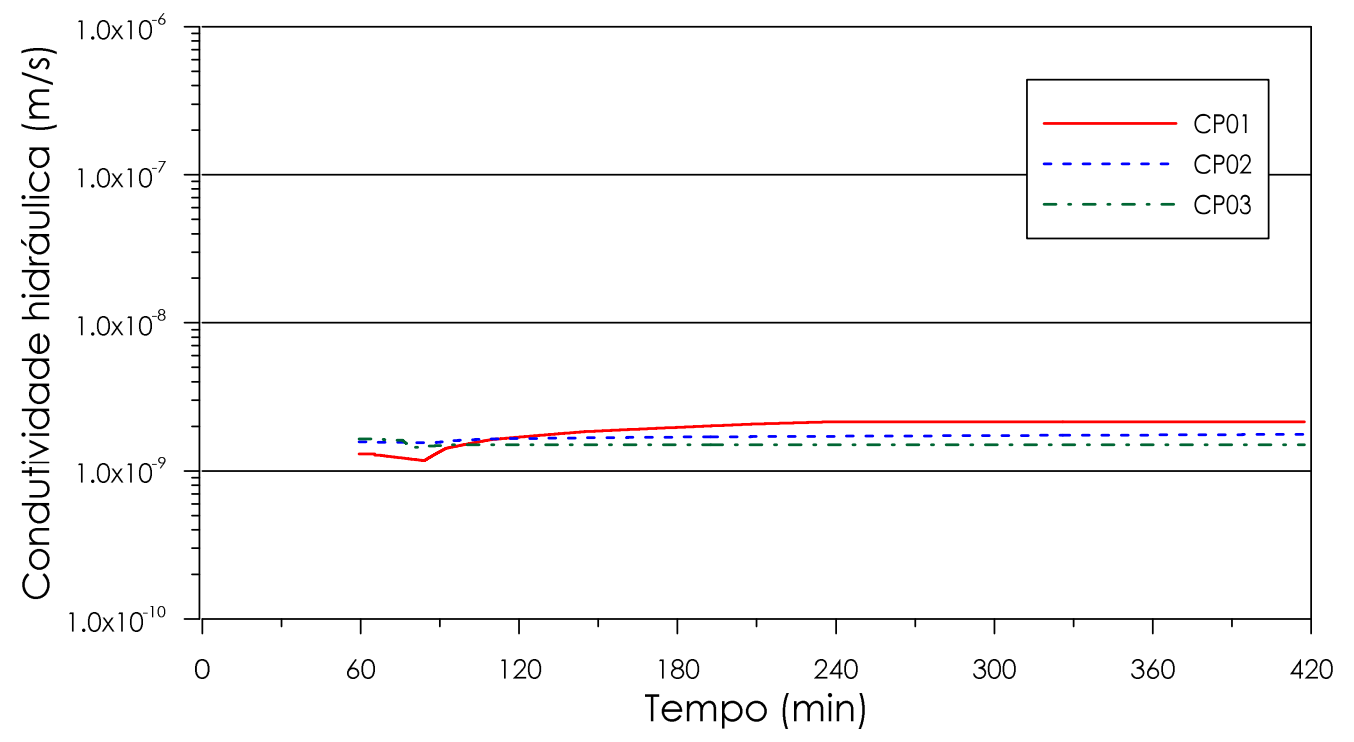

Figura 5.9: Condutividade hidráulica da mistura com $4 \%$ de bentonita

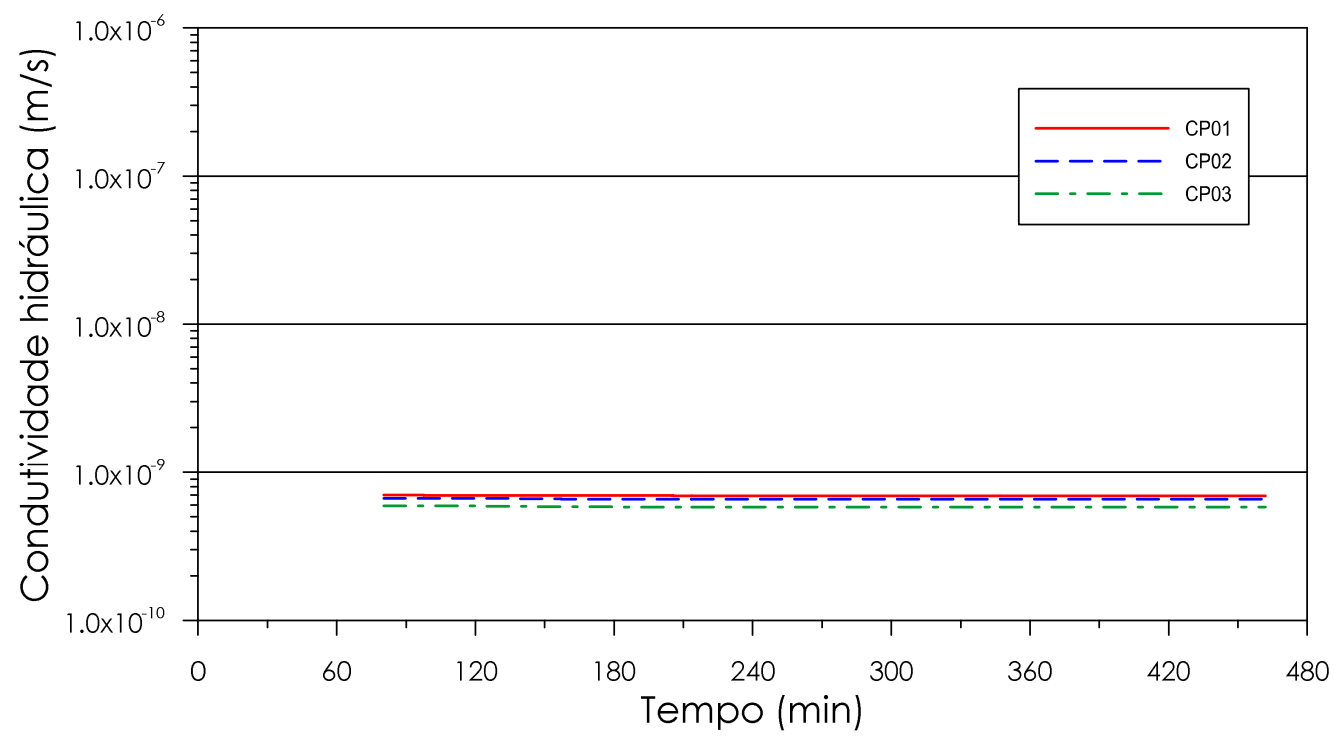

Figura 5.10: Condutividade hidráulica da mistura com $6 \%$ de bentonita

Tabela 5.5: Condutividade hidráulica de estabilização $(\mathrm{m} / \mathrm{s})$ do solo natural e das misturas solo-bentonita antes da fase de adensamento

\begin{tabular}{l|cccc}
\hline & CP 01 & CPO2 & CP 03 & Média \\
\hline S00 & $2,6.10^{-7}$ & $2,8 \cdot 10^{-7}$ & $4,5 \cdot 10^{-7}$ & $3,3 \cdot 10^{-7}$ \\
S02 & $4,7.10^{-8}$ & $5,2 \cdot 10^{-8}$ & $7,0.10^{-8}$ & $5,6 \cdot 10^{-8}$ \\
S04 & $2,1.10^{-9}$ & $1,8 \cdot 10^{-9}$ & $1,5 \cdot 10^{-9}$ & $1,8 \cdot 10^{-9}$ \\
S06 & $6,9 \cdot 10^{-10}$ & $6,6 \cdot 10^{-10}$ & $5,8 \cdot 10^{-10}$ & $6,4 \cdot 10^{-10}$ \\
\hline
\end{tabular}




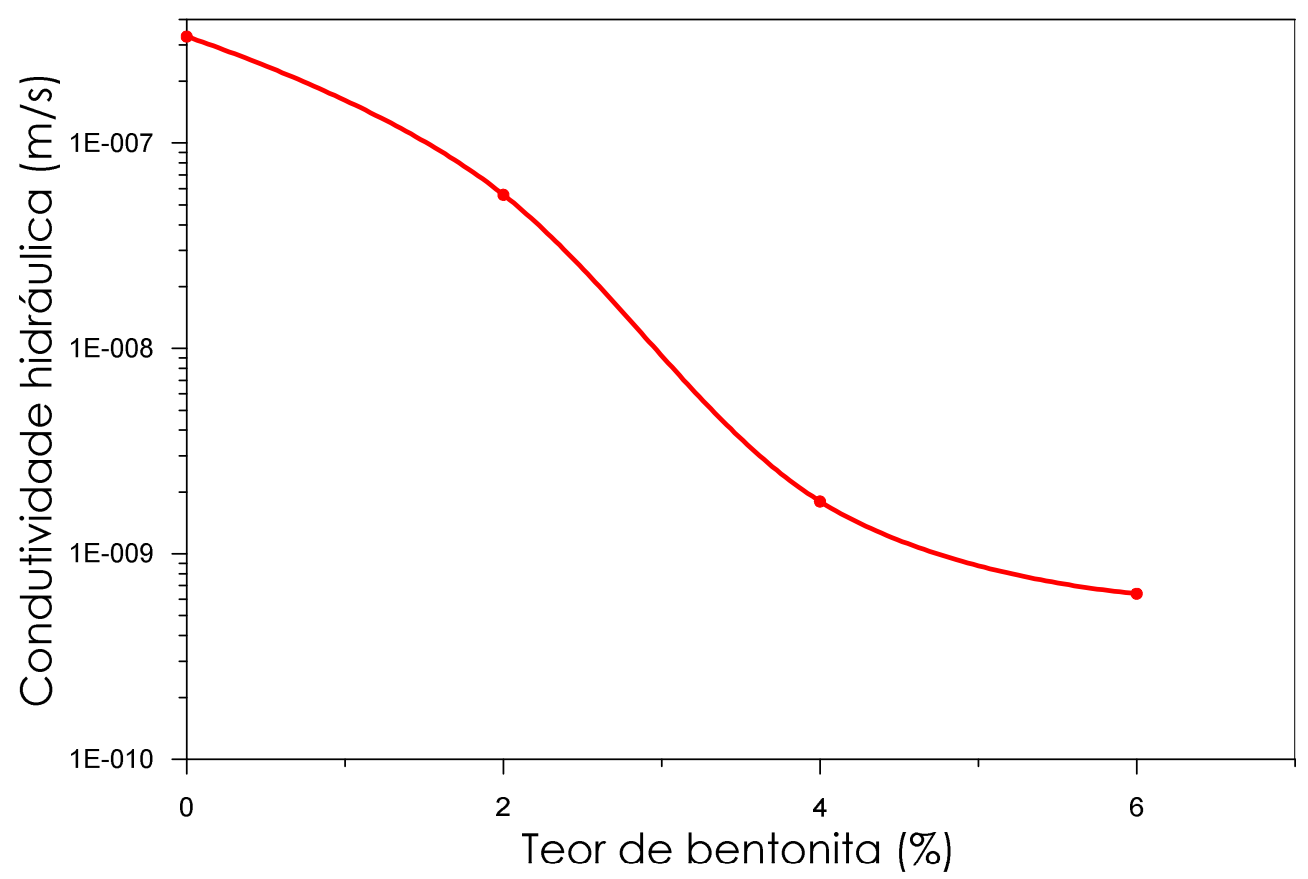

Figura 5.11. Variação da condutividade hidráulica média em função do teor de bentonita

\subsubsection{Fase de adensamento}

Os resultados para a fase de adensamento do ensaio foram plotadas em formas de curvas que representam a deformação volumétrica versus $\sqrt{t}$ em minutos (Figuras 5.12 a 5.15). Na Tabela 5.6 estão apresentadas as deformações volumétricas de estabilização, em \%, em função do teor de bentonita (em \%) e da tensão de confinamento, em kPa. 


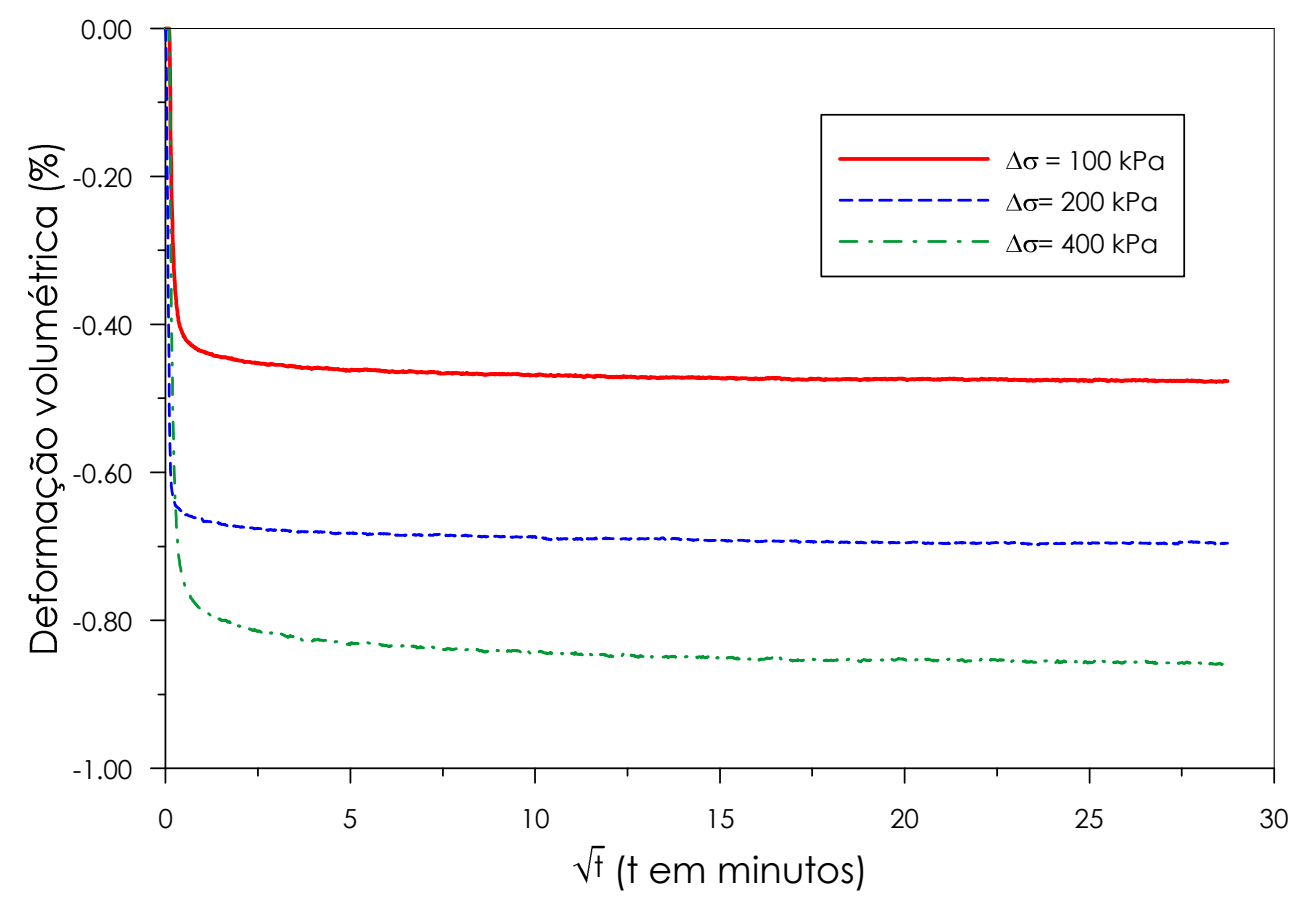

Figura 5.12: Curvas de adensamento do solo natural

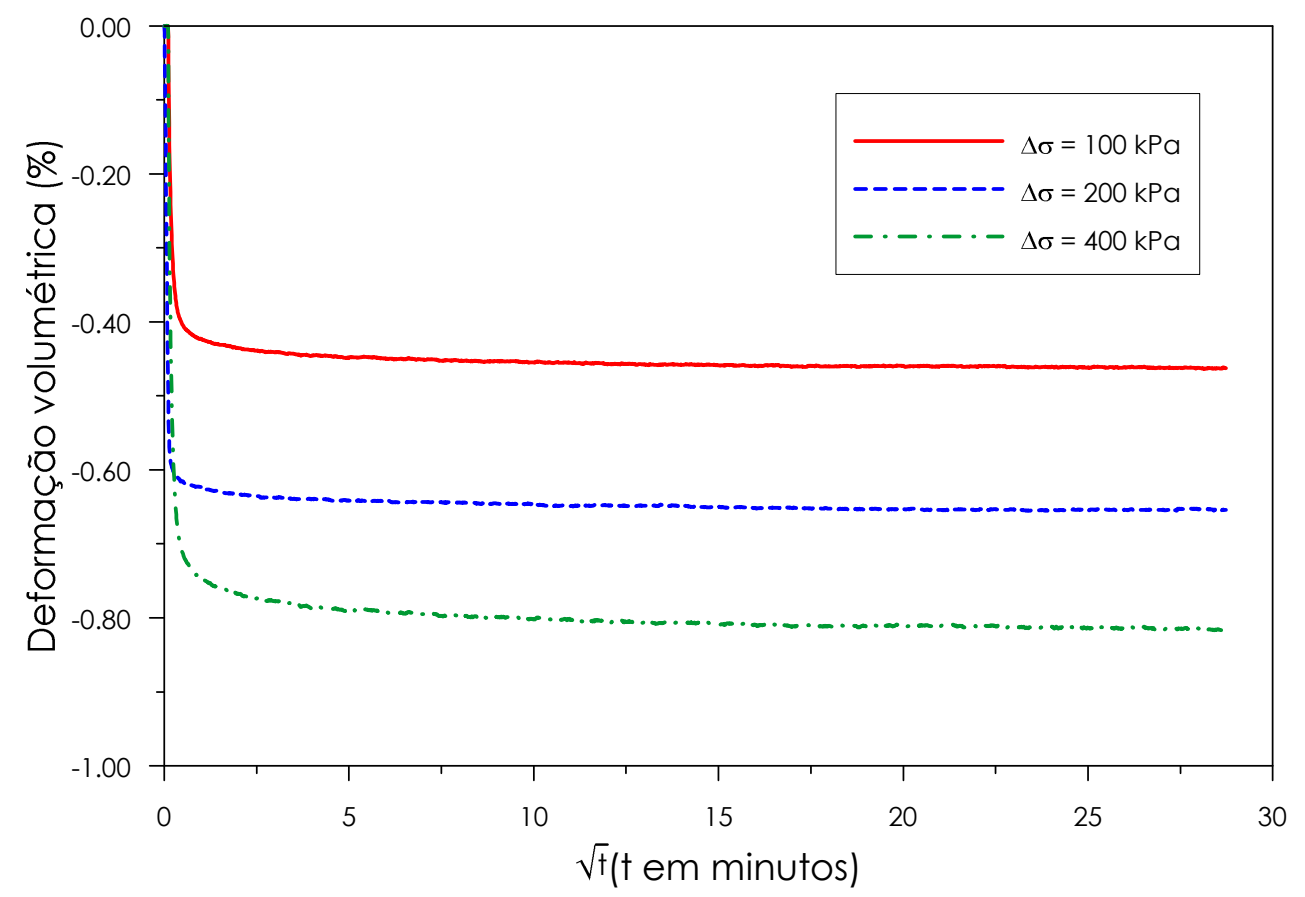

Figura 5.13: Curvas de adensamento da mistura com $2 \%$ de bentonita 


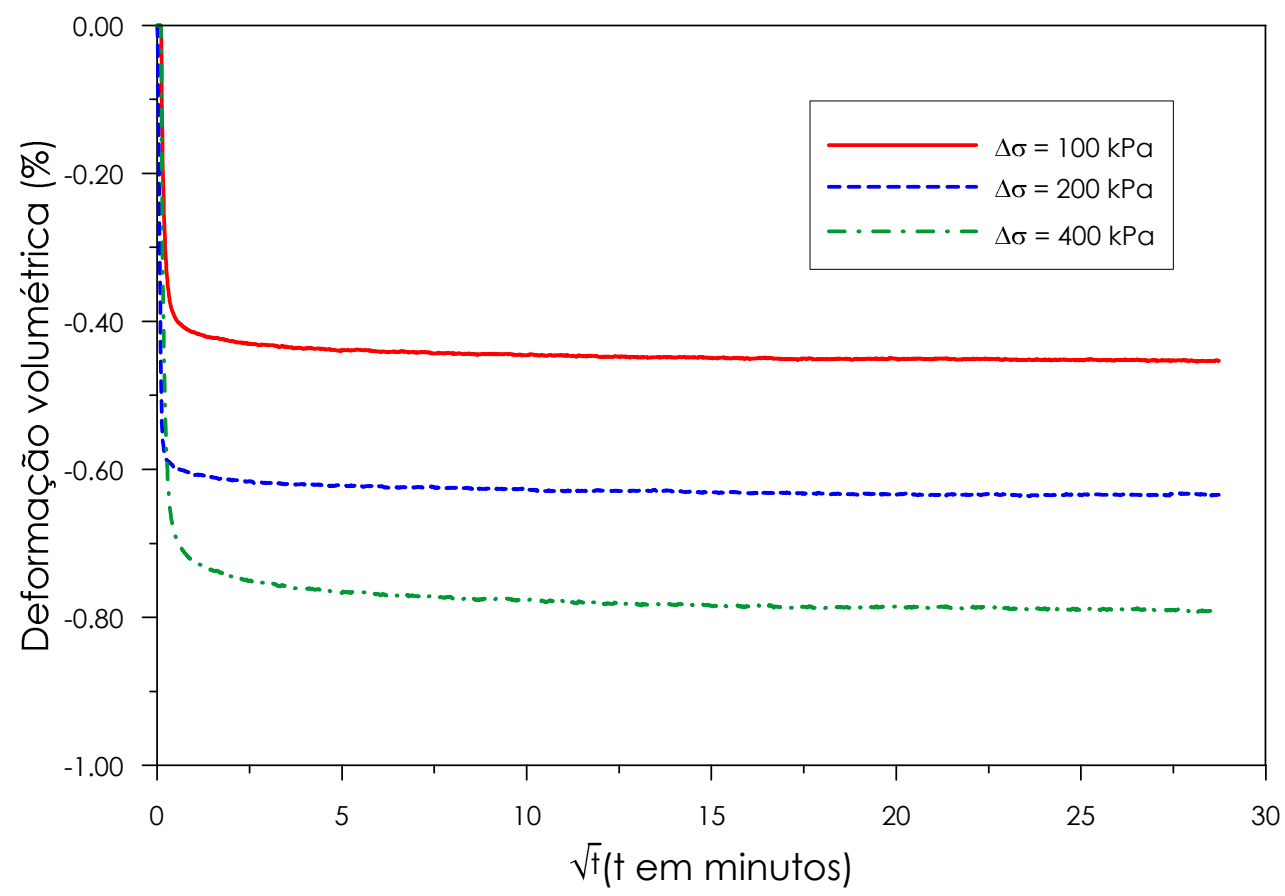

Figura 5.14: Curvas de adensamento da mistura com $4 \%$ de bentonita

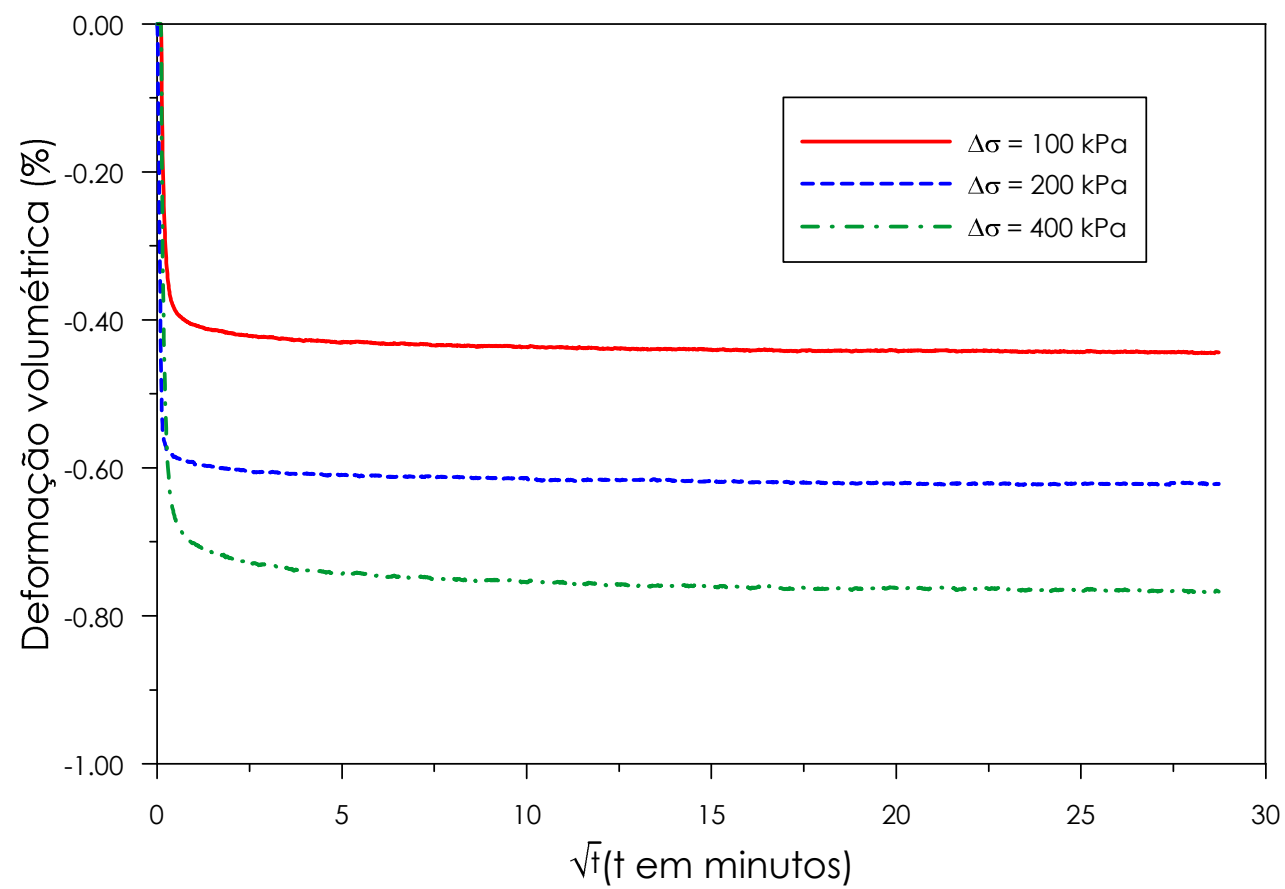

Figura 5.15: Curvas de adensamento da mistura com $6 \%$ de bentonita 
Tabela 5.6: Deformação volumétrica de estabilização (\%)

\begin{tabular}{l|ccc}
\hline & $\mathbf{1 0 0} \mathbf{k P a}$ & $\mathbf{2 0 0} \mathbf{k P a}$ & $\mathbf{4 0 0} \mathbf{k P a}$ \\
\hline S00 & $-0,478$ & $-0,697$ & $-0,855$ \\
S02 & $-0,466$ & $-0,654$ & $-0,813$ \\
S04 & $-0,454$ & $-0,635$ & $-0,790$ \\
S06 & $-0,441$ & $-0,623$ & $-0,768$ \\
\hline
\end{tabular}

A Tabela 5.7 apresenta os valores do índice de vazios antes e após o adensamento.

Com o intuito de facilitar a comparação dos dados, criou-se um índice denominado $\lambda$ dado pela Equação 5.1 .

$$
\lambda=\frac{e_{0}-e}{e} \times 100 \%
$$

onde:

$\mathrm{e}_{0}=$ índice de vazios antes do adensamento;

e = índice de vazios após o adensamento.

Tabela 5.7: Variação do índice de vazios com o teor de bentonita e a tensão confinante

\begin{tabular}{|c|c|c|c|c|}
\hline \multirow{2}{*}{$\sigma_{3}(\mathrm{kPa})$} & \multicolumn{4}{|c|}{$e_{0}$} \\
\hline & SOO & SO2 & SO4 & S06 \\
\hline 100 & 0,406 & 0,421 & 0,444 & 0,457 \\
\hline 200 & 0,413 & 0,421 & 0,433 & 0,452 \\
\hline 400 & 0,392 & 0,418 & 0,439 & 0,455 \\
\hline \multirow{2}{*}{$\sigma_{3}(\mathrm{kPa})$} & \multicolumn{4}{|c|}{$e$} \\
\hline & SOO & SO2 & SO4 & S06 \\
\hline tv 100 & 0,401 & 0,415 & 0,435 & 0,448 \\
\hline 200 & 0,407 & 0,412 & 0,422 & 0,439 \\
\hline 400 & 0,384 & 0,408 & 0,426 & 0,440 \\
\hline \multirow{2}{*}{$\sigma_{3}(\mathrm{kPa})$} & \multicolumn{4}{|c|}{$\lambda(\%)$} \\
\hline & SOO & SO2 & SO4 & S06 \\
\hline 100 & 1,07 & 1,42 & 1,88 & 2,08 \\
\hline 200 & 1,50 & 2,16 & 2,54 & 2,96 \\
\hline 400 & 2,29 & 2,70 & 3,07 & 3,43 \\
\hline
\end{tabular}


A partir da análise da Tabela 5.7 constata-se que o índice de vazios aumenta com o acréscimo de bentonita. Com o parâmetro $\lambda$ constata-se que o solo ficou mais compressível com o acréscimo de bentonita.

\subsubsection{Ensaios para a determinação da condutividade hidráulica após a fase de adensamento}

Os resultados dos ensaios de condutividade hidráulica do solo natural e das misturas solo-bentonita após a fase de adensamento estão apresentados nas Figuras 5.16 a 5.19. O resumo destes resultados está apresentado na Tabela 5.8 .

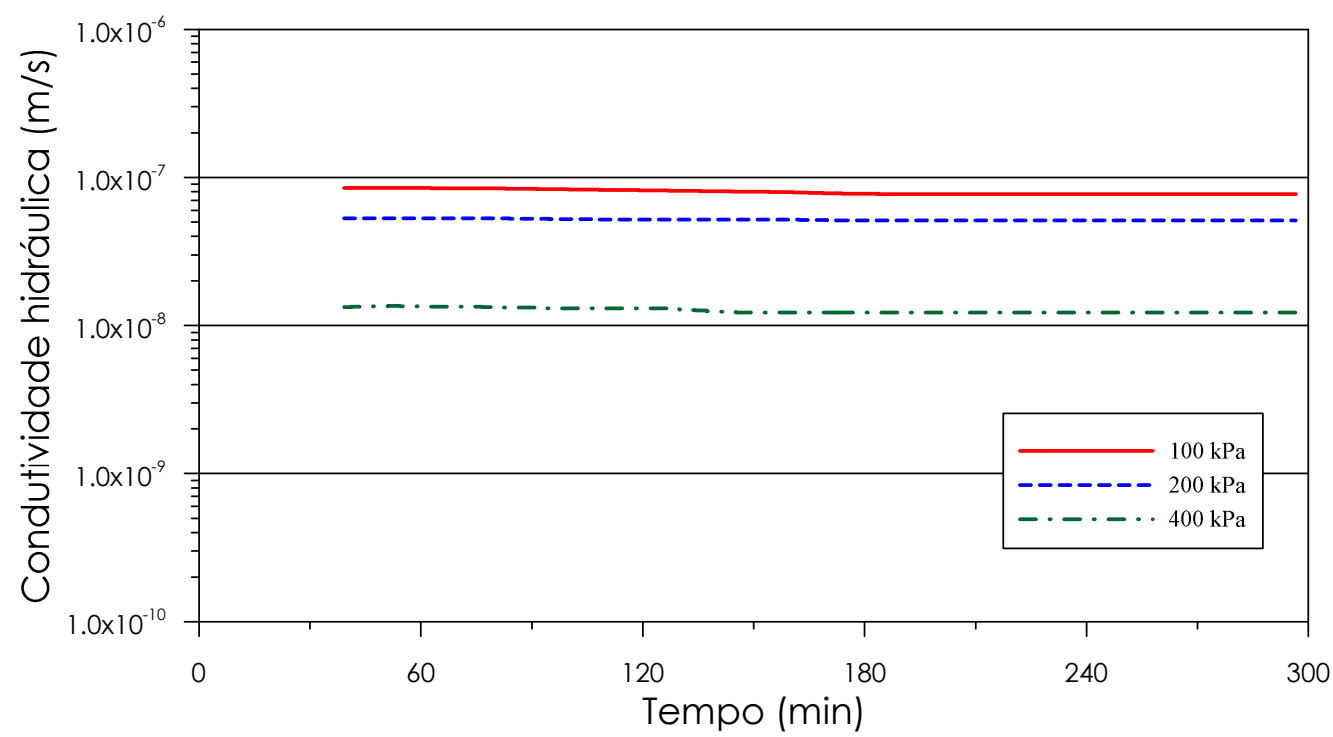

Figura 5.16: Condutividade hidráulica do solo natural após a fase de adensamento 


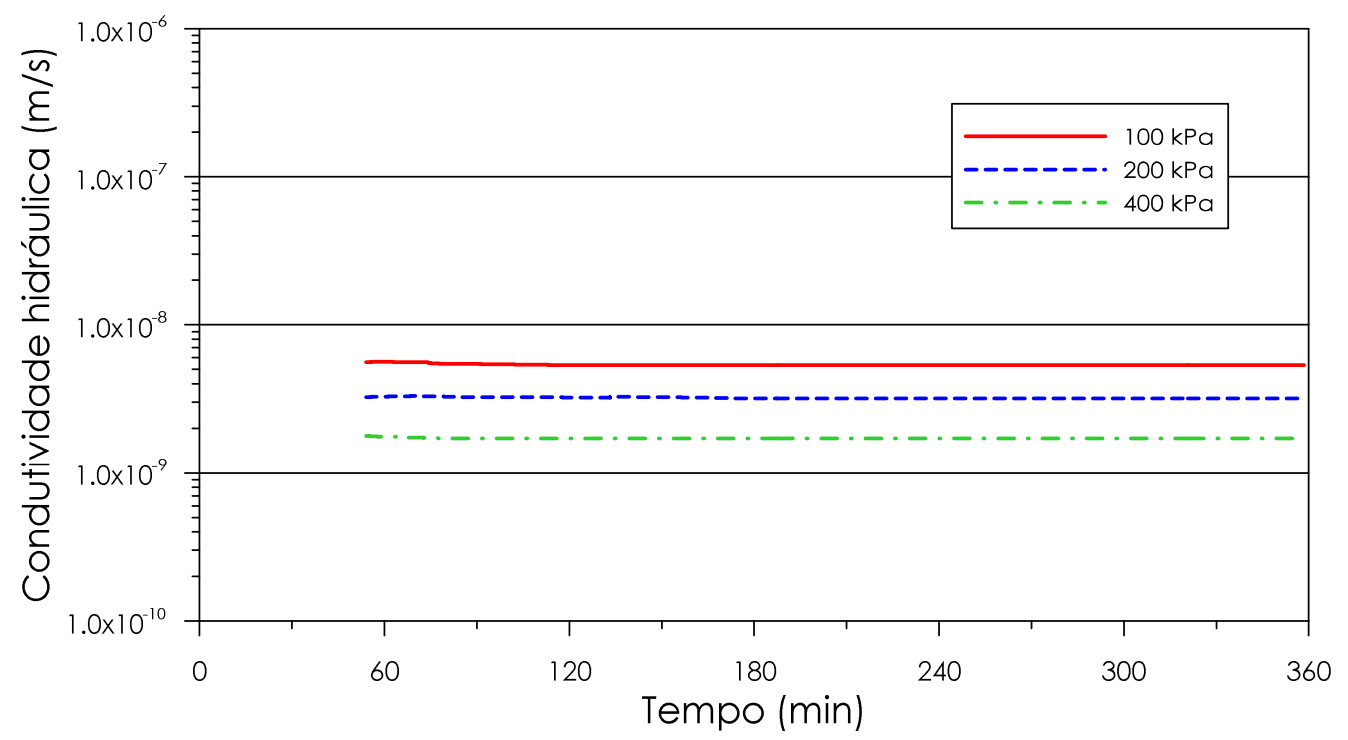

Figura 5.17: Condutividade hidráulica da mistura com $2 \%$ de bentonita após a fase de adensamento

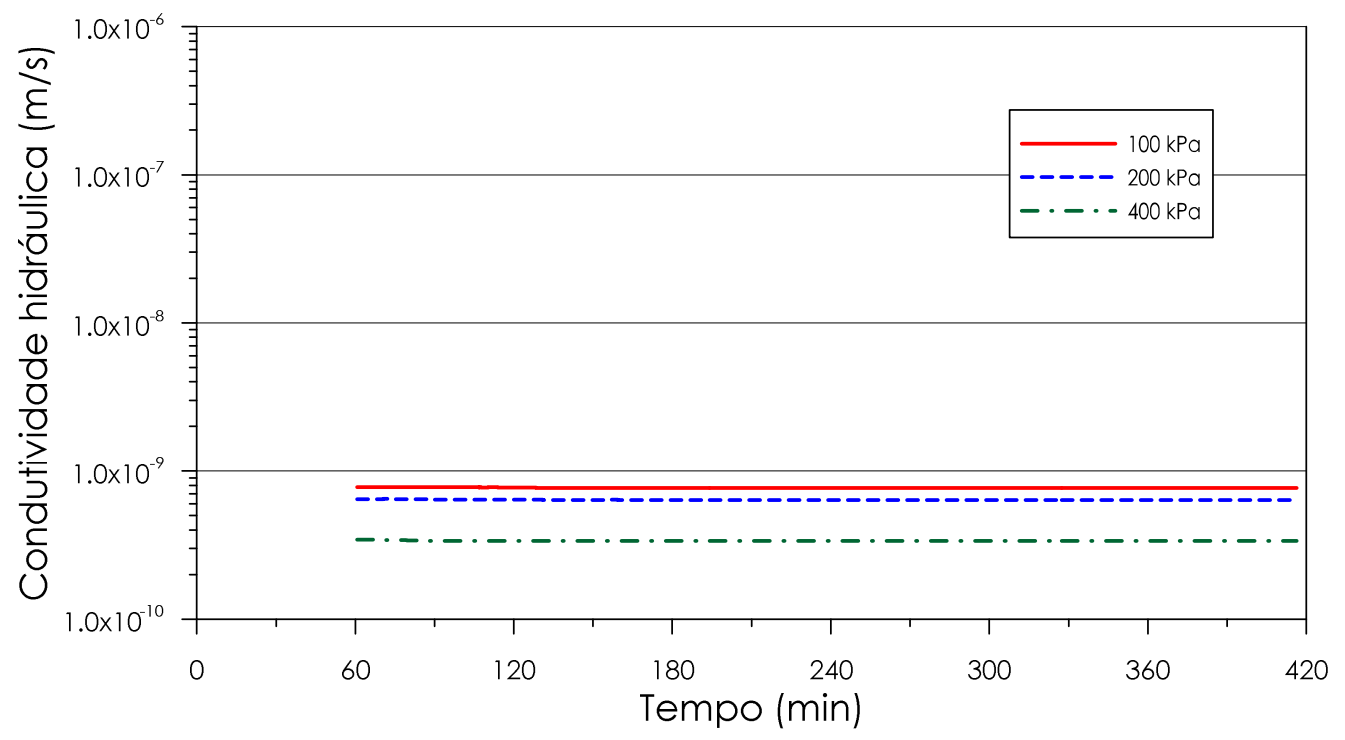

Figura 5.18: Condutividade hidráulica da mistura com $4 \%$ de bentonita após a fase de adensamento 


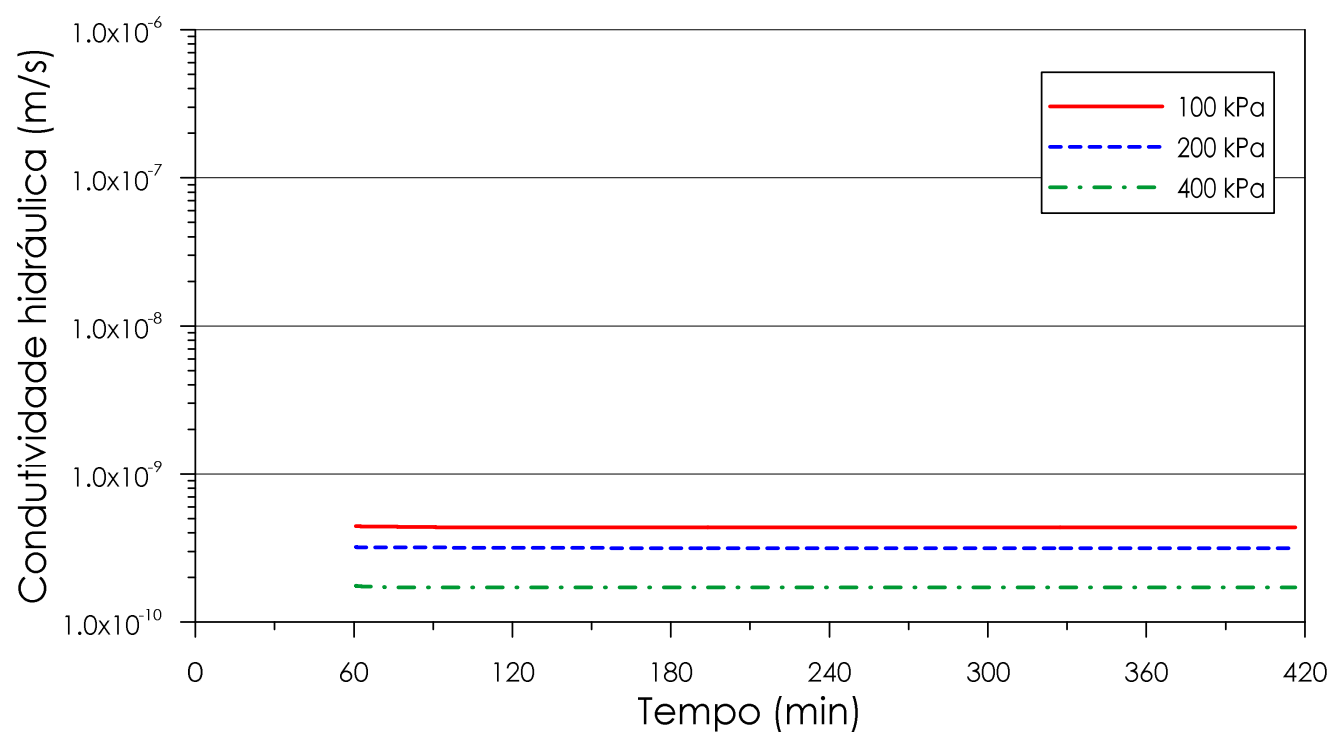

Figura 5.19: Condutividade hidráulica da mistura com $6 \%$ de bentonita após a fase de adensamento

Tabela 5.8: Condutividade hidráulica $(\mathrm{m} / \mathrm{s})$ do solo natural e das misturas solo-bentonita para diferentes tensões de confinamento

\begin{tabular}{l|cccc}
\hline & $\mathbf{0 ~} \mathbf{~ P a}$ & $100 \mathrm{kPa}$ & $200 \mathrm{kPa}$ & $\mathbf{4 0 0} \mathbf{~ P a}$ \\
\hline S00 & $3,3 \times 10^{-7}$ & $7,7 \times 10^{-8}$ & $5,1 \times 10^{-8}$ & $1,2 \times 10^{-8}$ \\
S02 & $5,6 \times 10^{-8}$ & $5,3 \times 10^{-9}$ & $3,2 \times 10^{-9}$ & $1,7 \times 10^{-9}$ \\
S04 & $5,4 \times 10^{-9}$ & $7,7 \times 10^{-10}$ & $6,4 \times 10^{-10}$ & $3,4 \times 10^{-10}$ \\
S06 & $6,4 \times 10^{-10}$ & $4,4 \times 10^{-10}$ & $3,2 \times 10^{-10}$ & $1,7 \times 10^{-10}$ \\
\hline
\end{tabular}

A Figura 5.20 apresenta os resultados de condutividade hidráulica em função da tensão de confinamento e do teor de bentonita.

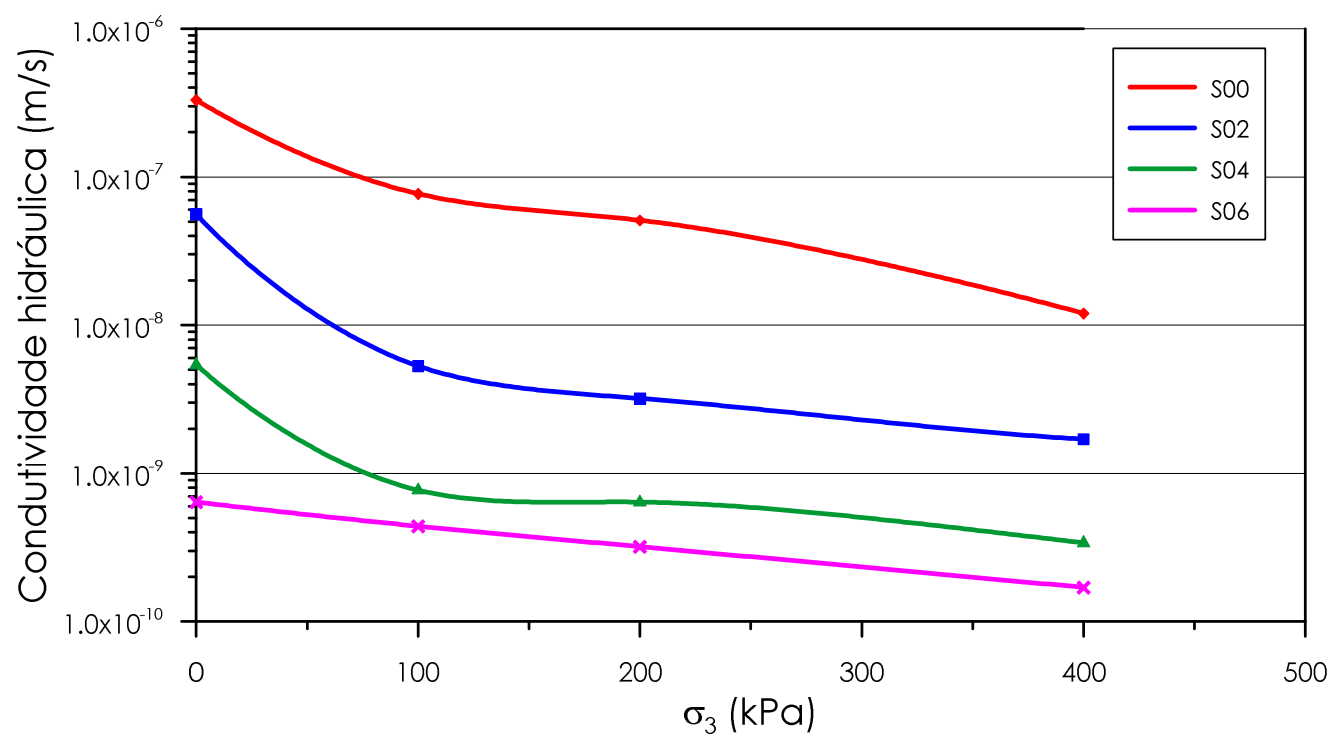

Figura 5.20: Condutividade hidráulica em função da tensão de confinamento e teor de bentonita 
Como era esperado, a condutividade hidráulica diminui tanto com o acréscimo de bentonita quanto com o aumento da tensão de confinamento. $O$ acréscimo de $6 \%$ de bentonita ao solo natural causou uma diminuição na condutividade hidráulica da ordem de 1000 vezes (de 10-7 para 10-10 m/s). Desta forma, esta é a única mistura que o atende o requisito de condutividade hidráulica das normas ambientais para uso em barreiras de fundo de aterros sanitários. Constata-se também que os pontos apresentam uma tendência assintótica, o que aponta para um limite na redução da condutividade hidráulica com o acréscimo de bentonita.

Para uma melhor compreensão do comportamento da condutividade hidráulica em função do teor de bentonita e tensão confinante, foi definido um índice de condutividade hidráulica, que é a relação entre a condutividade hidráulica da mistura e a condutividade hidráulica do solo natural (Tabela 5.9).

Tabela 5.9: Índices de condutividade hidráulica das amostras estudadas

\begin{tabular}{c|cccc}
\hline & S00 & S02 & S04 & S06 \\
\hline $\mathbf{1 0 0 ~ k P a}$ & $100 \%$ & $6,88 \%$ & $1,00 \%$ & $0,57 \%$ \\
$\mathbf{2 0 0} \mathbf{~ k P a}$ & $100 \%$ & $6,27 \%$ & $1,25 \%$ & $0,63 \%$ \\
$\mathbf{4 0 0} \mathbf{~ k P a}$ & $100 \%$ & $14,17 \%$ & $2,83 \%$ & $1,42 \%$ \\
\hline
\end{tabular}

\subsubsection{Ensaios para a determinação da resistência ao cisalhamento}

As curvas de tensão desviatória e pressão neutra versus deformação axial durante a fase de cisalhamento são apresentadas nas Figuras 5.21 a 5.24. 


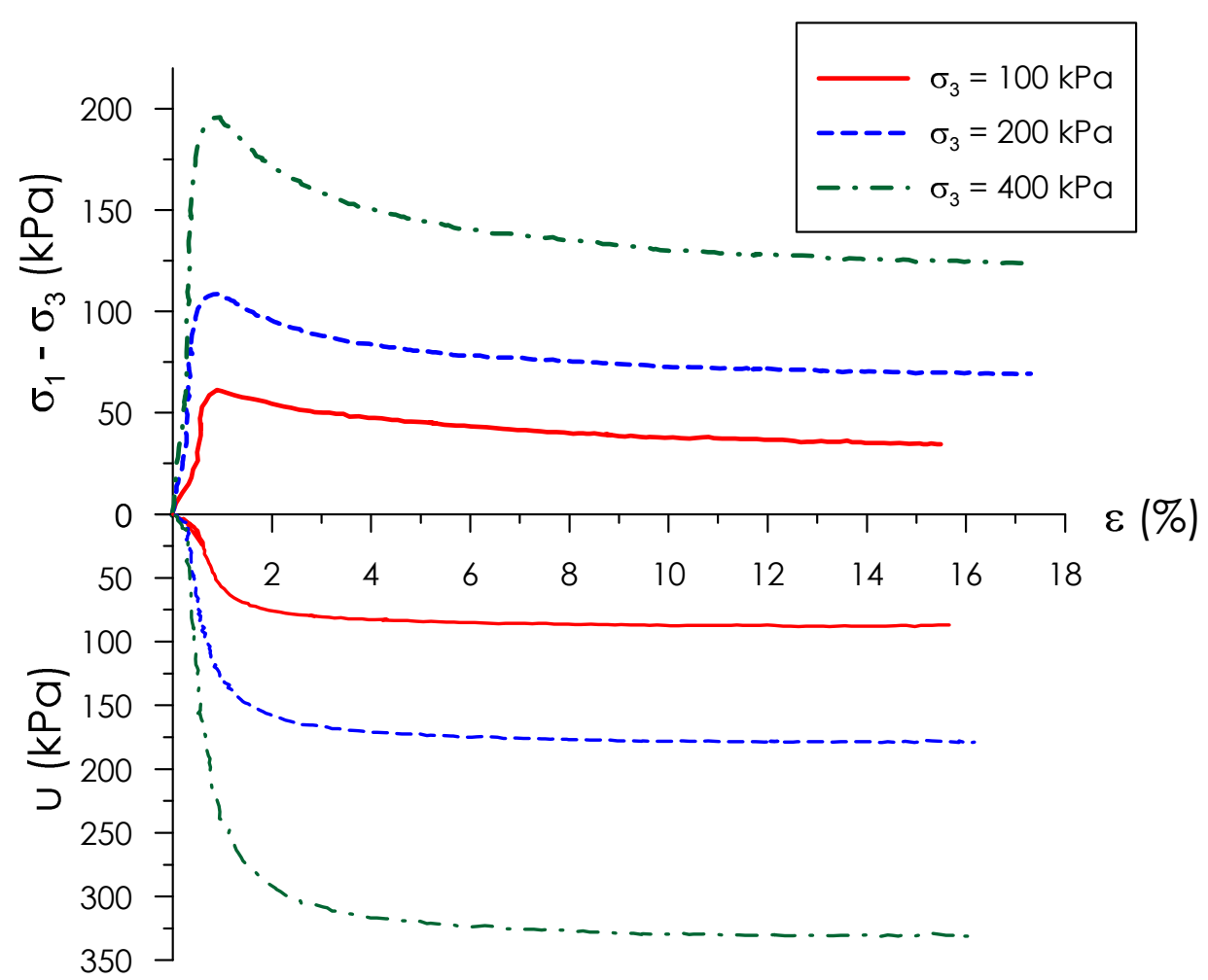

Figura 5.21: Curvas da tensão desviatória e pressão netutra versus deformação axial para o solo natural.

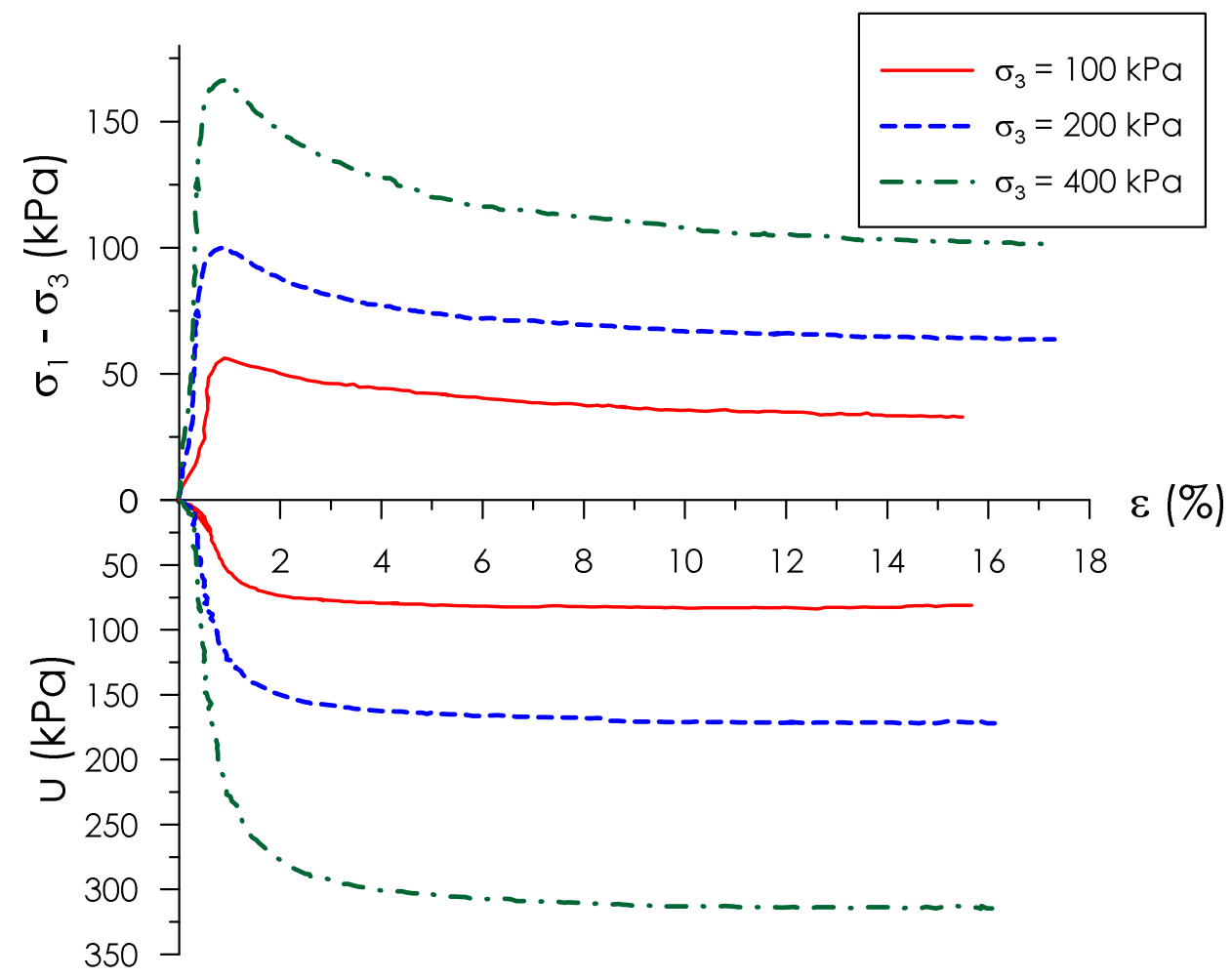

Figura 5.22: Curvas da tensão desviatória e pressão neutra versus deformação axial para a mistura com $2 \%$ de bentonita 


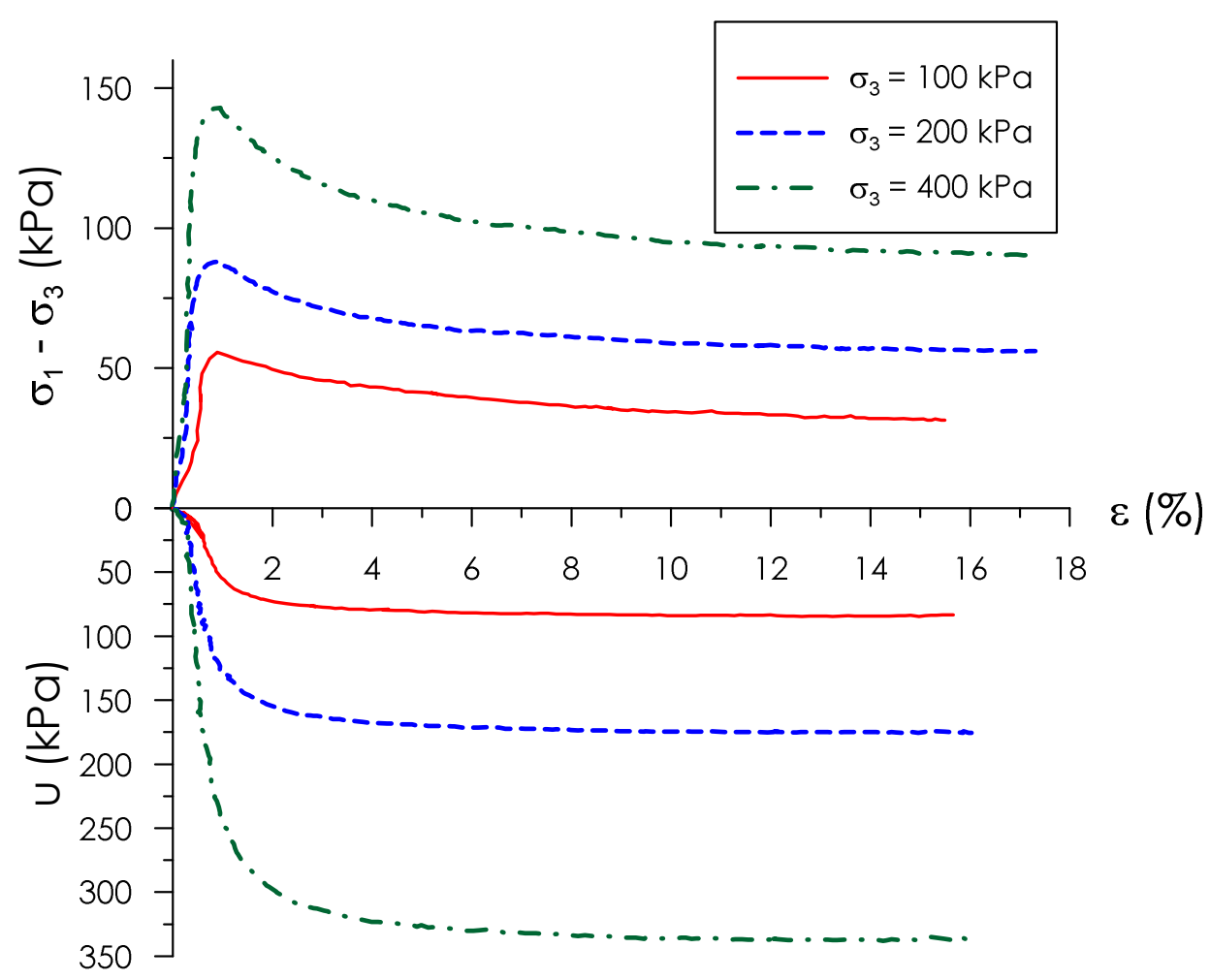

Figura 5.23: Curvas da tensão desviatória e pressão neutra versus deformação axial para a mistura com $4 \%$ de bentonita

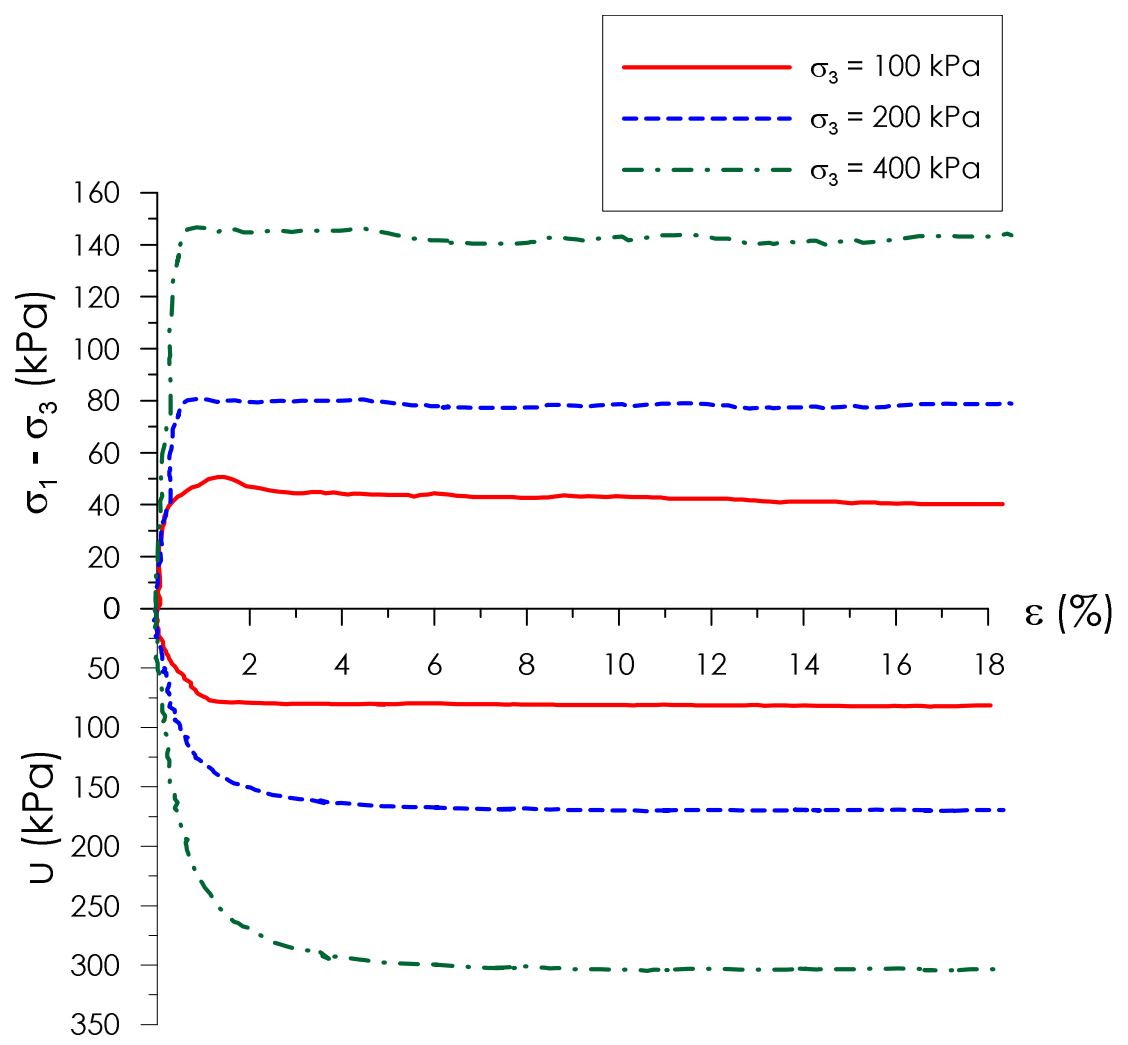

Figura 5.24: Curvas da tensão desviatória e pressão neutra versus deformação axial para a mistura com 6\% de bentonita. 
Constata-se que as curvas correspondentes a 0, 2 e $4 \%$ de bentonita apresentaram o comportamento de areia compacta, enquanto a as curvas correspondentes a $6 \%$ de bentonita apresentou um comportamento de argila normalmente adensada. Desta forma, o acréscimo de $6 \%$ de bentonita foi suficiente para mudar o comportamento tensão $x$ deformação da mistura.

As Figuras 25 a 32 mostram as envoltórias de resistência, em termos de tensões totais e efetivas, do solo natural e das misturas solo-bentonita analisadas.

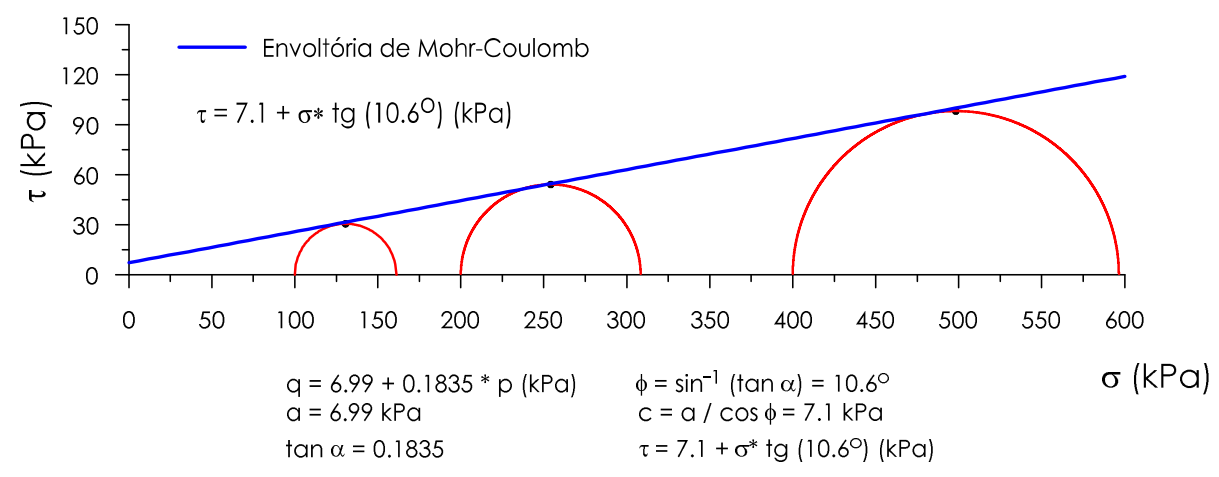

Figura 5.25: Envoltória de resistência em termos de tensões totais do solo natural

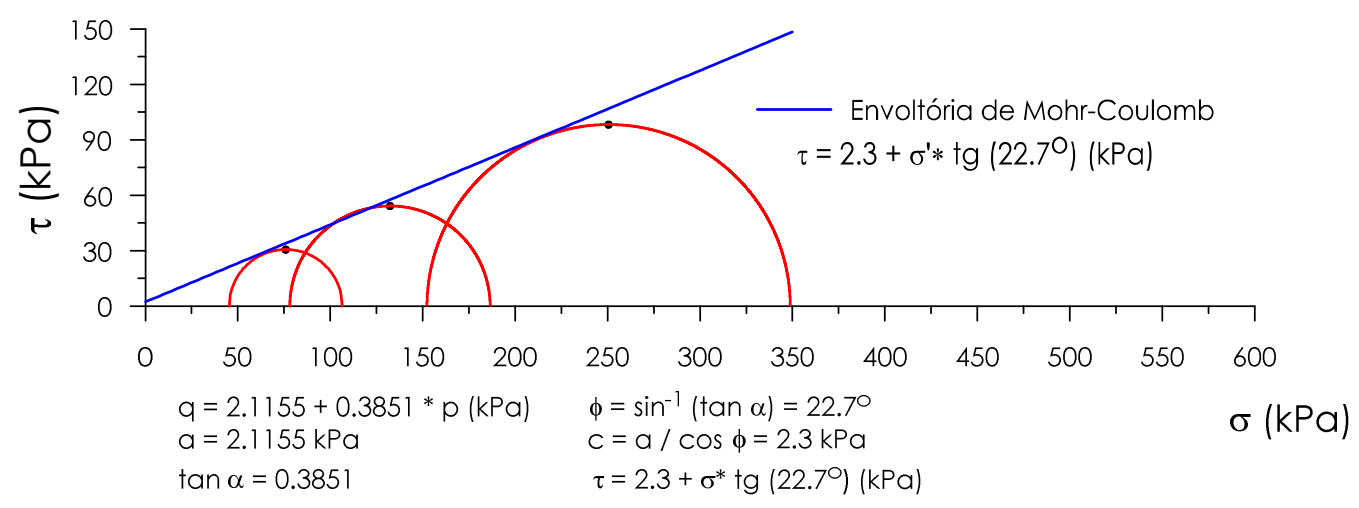

Figura 5.26: Envoltória de resistência em termos de tensões efetivas do solo natural 


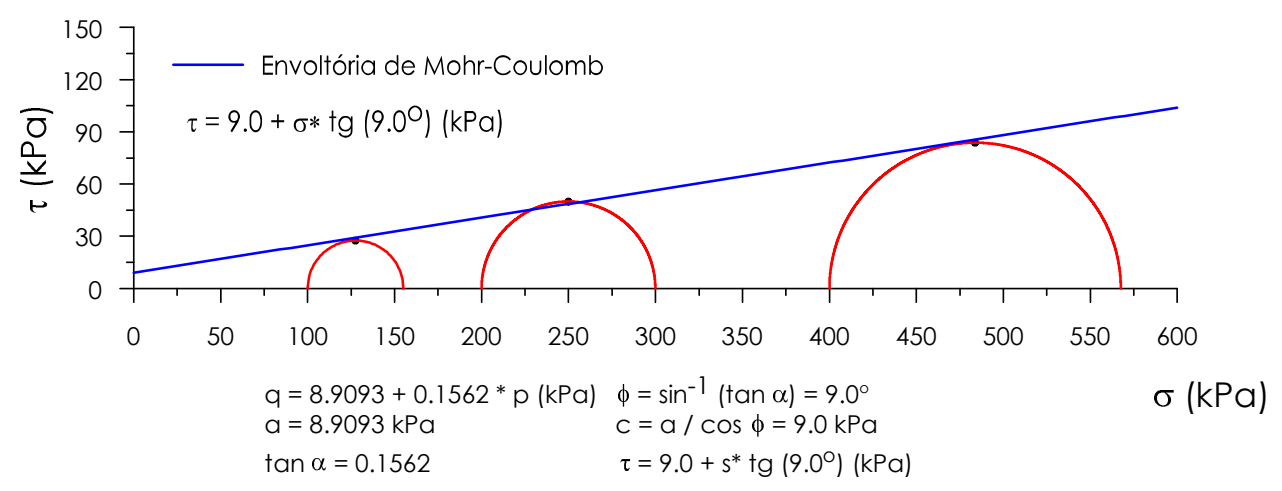

Figura 5.27: Envoltória de resistência em termos de tensões totais da mistura com $2 \%$ de bentonita

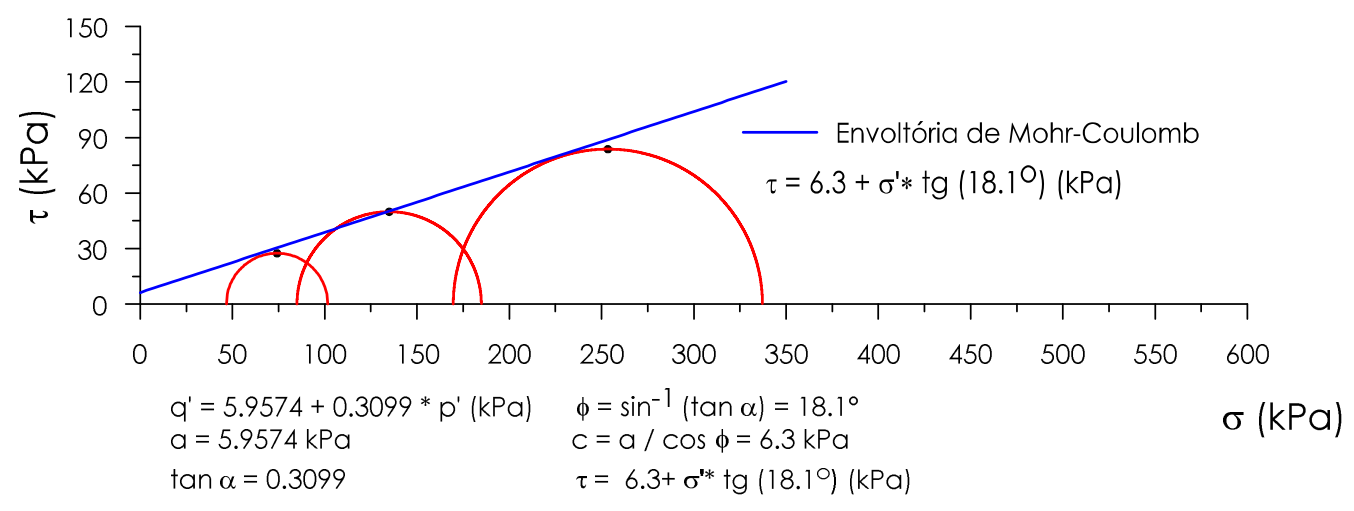

Figura 5.28: Envoltória de resistência em termos de tensões efetivas da mistura com $2 \%$ de bentonita

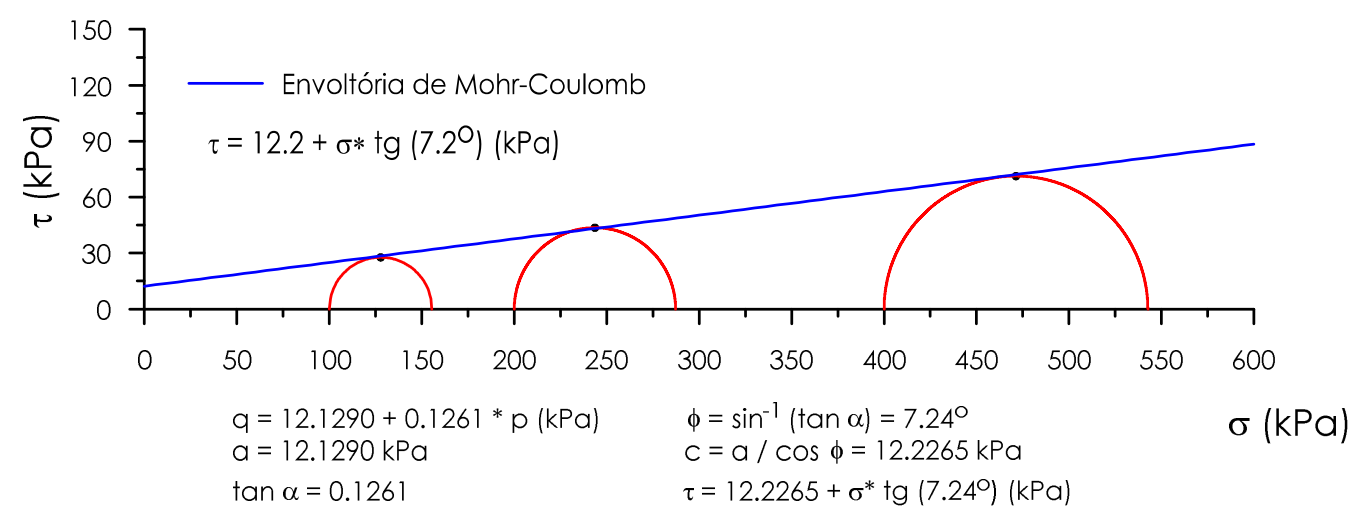

Figura 5.29: Envoltória de resistência em termos de tensões totais da mistura com $4 \%$ de bentonita 


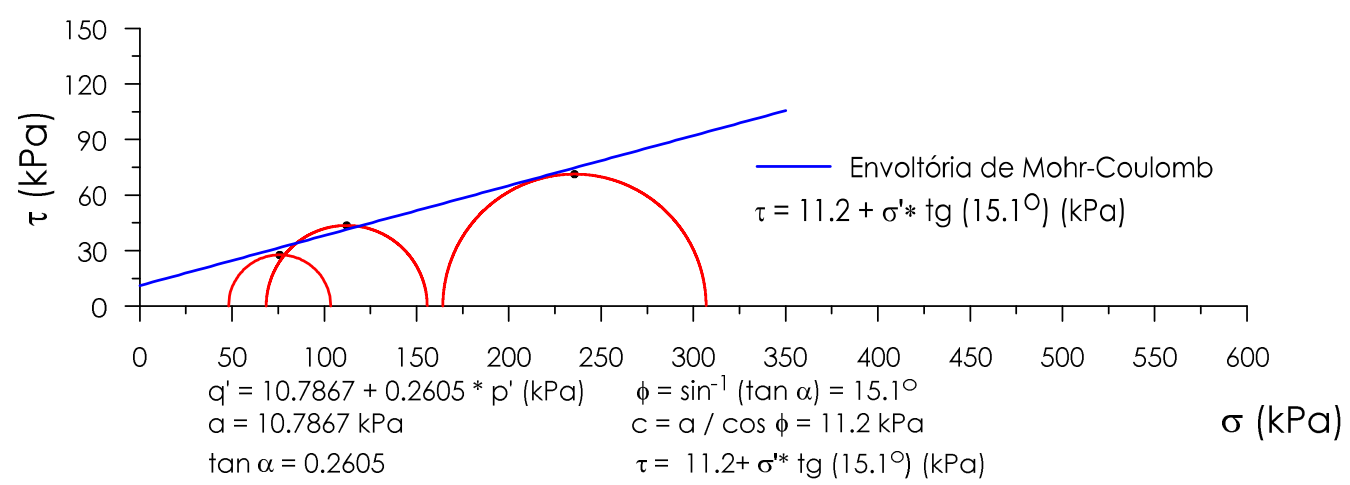

Figura 5.30: Envoltória de resistência em termos de tensões efetivas da mistura com $4 \%$ de bentonita

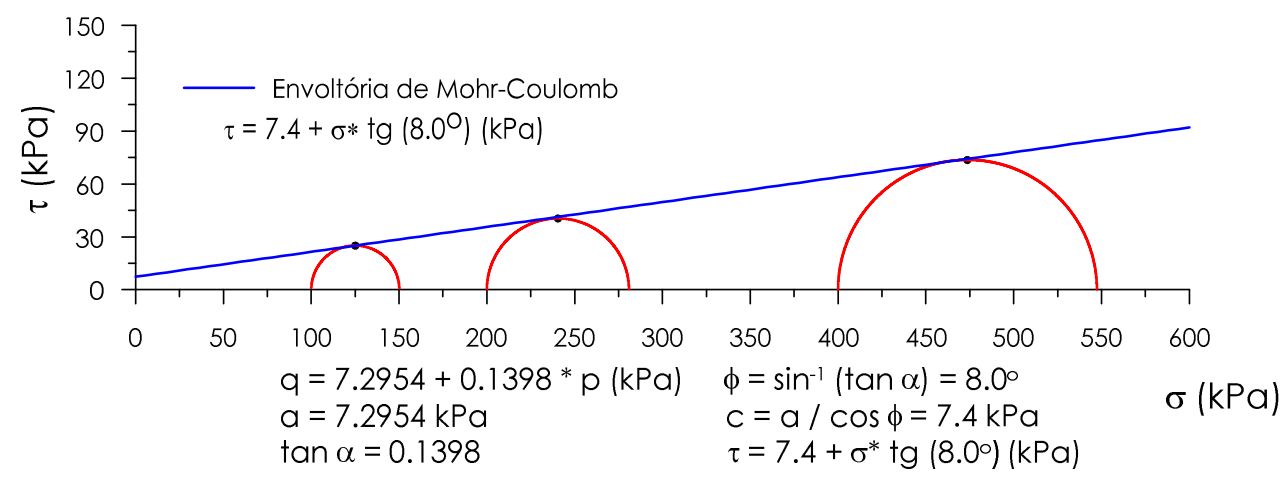

Figura 5.31: Envoltória de resistência em termos de tensões totais da mistura com $6 \%$ de bentonita

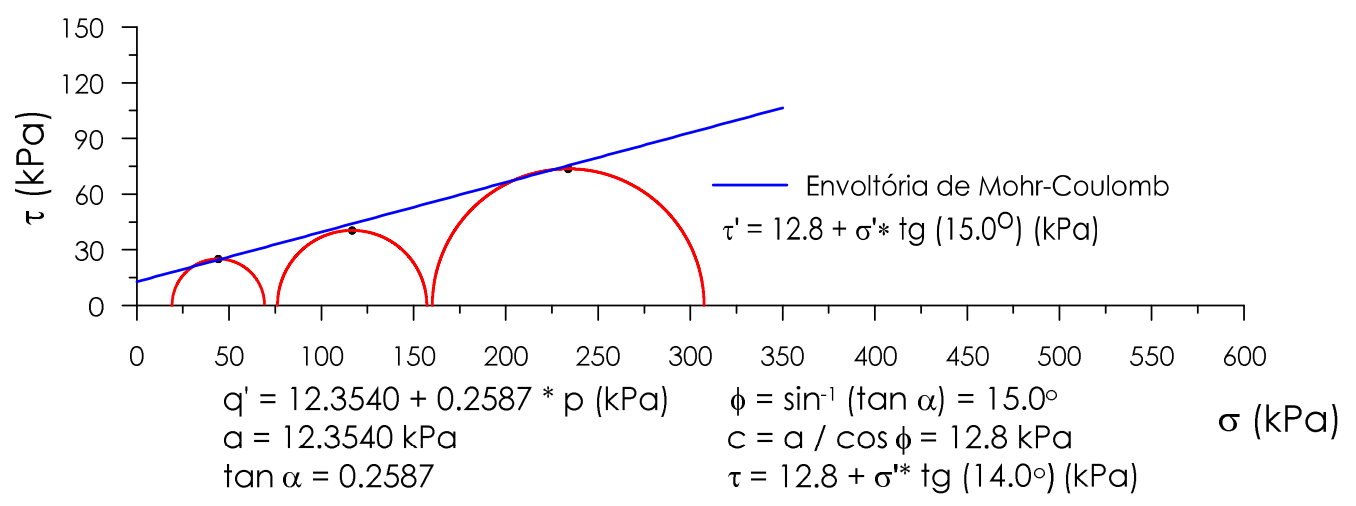

Figura 5.32: Envoltória de resistência em termos de tensões efetivas da mistura com $6 \%$ de bentonita 
A Figura 5.33 apresenta a influência da bentonita na tensão desviatória máxima do solo estudado. Desta forma, nesta figura, para um determinado nível de tensão de confinamento, é mostrada a variação da tensão desviatória com o teor de bentonita adicionado ao solo estudado.

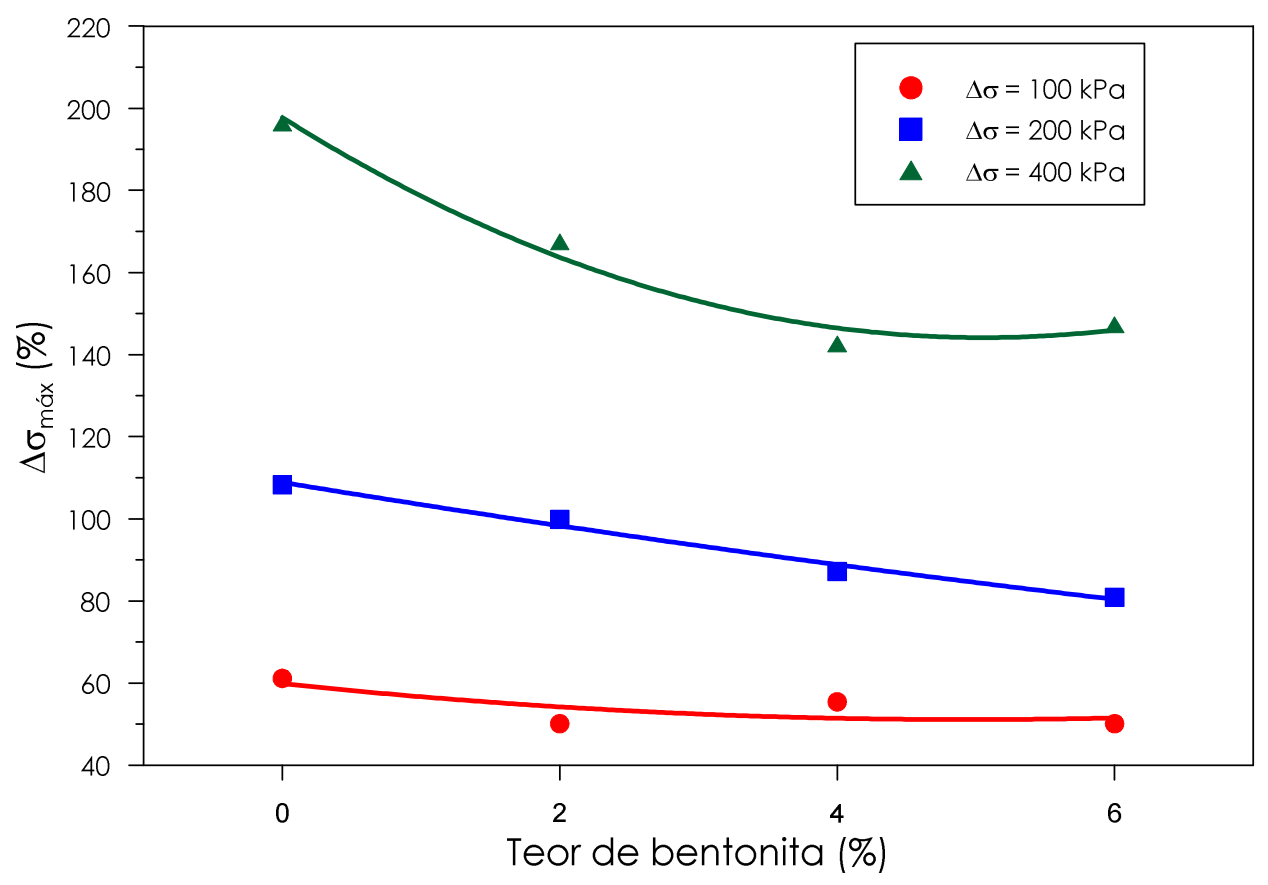

Figura 5.33: Tensão de desvio na ruptura em função do teor de bentonita

A tensão desviatória na ruptura apresentou um comportamento similar para todas as tensões de confinamento. O solo natural apresentou um tensão desviatória na ruptura superior ao de todas as misturas. Com o acréscimo de bentonita essa tensão apresenta um decréscimo de até, aproximadamente, tender a uma estabilização. Lukiantchuki (2007) encontrou um comportamento semelhante a este. Entretanto, entre $5 \%$ e $9 \%$ de acréscimo de bentonita, esse autor detectou um aumento nesse parâmetro.

A Figura 5.34 apresenta a variação da coesão efetiva e do ângulo de atrito efetivo com o acréscimo de bentonita ao solo. Conforme era esperado, a coesão efetiva aumentou com o acréscimo de bentonita. Isto provavelmente ocorre devido ao fato de a coesão estar altamente relacionada com a quantidade de finos do solo. Por outro lado, o ângulo de atrito efetivo diminuiu com o acréscimo de bentonita ao solo. Acredita-se que isto 
ocorra devido ao efeito de "Iubrificação" que os grãos finos da bentonita ocasionam quando misturados a um solo arenoso.

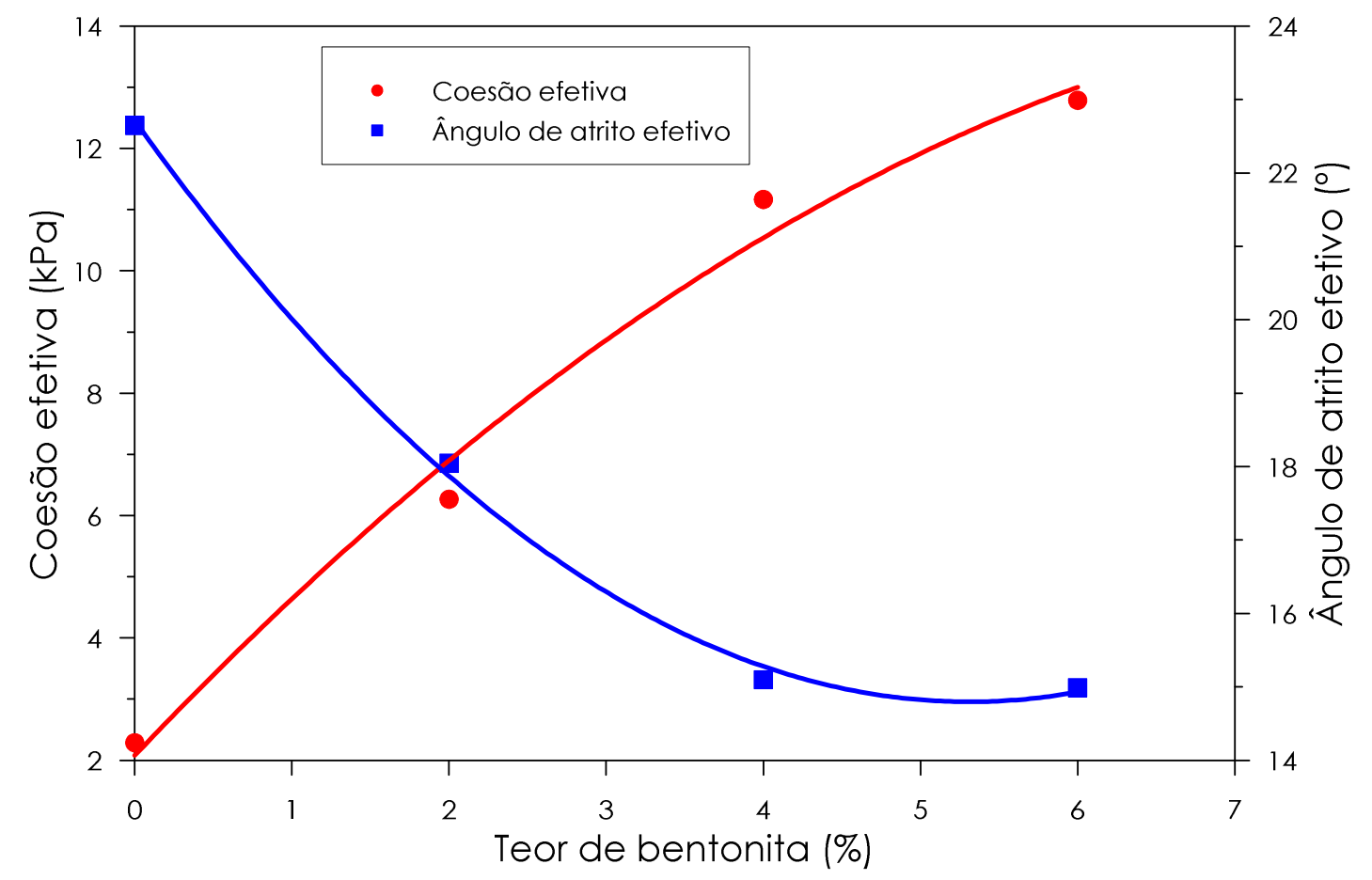

Figura 5.34: Variação da coesão efetiva e ângulo de atrito efetivo em função do teor de bentonita

\subsubsection{Critério para a escolha de solos a serem utilizados como barreiras impermeabilizantes}

Solos utilizados como barreiras de fundo de aterros sanitários devem apresentar determinadas características que assegurem a estanqueidade do aterro. Desta forma, comparou-se parâmetros do solo natural e das misturas solo bentonita com os critérios estabelecidos pela CETESB para que um solo possa ser utilizado como barreira de fundo. Fazendo-se esta comparação, constata-se que a mistura com $6 \%$ de bentonita é a única atende todos os requisitos estabelecidos pela CETESB, estando, desta forma, apta a atuar como o solo para a construção da camada de fundo do aterro sanitário de Rio Grande. 
Tabela 5.10: Comparação entre os requisitos da CETESB (1993) e os parâmetros do solo natural e das misturas solo-bentonitada mistura com $6 \%$ de bentonita

\begin{tabular}{|c|c|c|c|c|c|}
\hline & $\begin{array}{l}\text { CETESB } \\
(1993)\end{array}$ & 500 & SO2 & S04 & S06 \\
\hline Classificação USCS & $\begin{array}{c}\mathrm{CL}, \mathrm{CH}, \mathrm{SC} \\
\text { ou } \mathrm{OH}\end{array}$ & SC & SC & SC & SC \\
\hline Condutividade hidráulica $(\mathrm{m} / \mathrm{s})$ & $<1 \times 10^{-9}$ & $3,3 \times 10^{-7}$ & $5,4 \times 10^{-8}$ & $5,4 \times 10^{-9}$ & $6,4 \times 10^{-10}$ \\
\hline $\begin{array}{c}\text { Porcentagem passante na } \\
\text { peneira de abertura } 0,075 \mathrm{~mm} \\
(\# 200)(\%)\end{array}$ & $\geq 30$ & 42,5 & 45,3 & 45,6 & 45,92 \\
\hline Limite de liquidez (\%) & $\geq 30$ & 32 & 42 & 45 & 48 \\
\hline Índice de plasticidade (\%) & $\geq 15$ & 16 & 26 & 29 & 31 \\
\hline pH em água & $\geq 7$ & 5,41 & 6,91 & 7,49 & 8,63 \\
\hline
\end{tabular}




\section{Capítulo 6 Conclusões}

\subsection{Conclusões}

A condutividade hidráulica do solo natural avaliado neste trabalho é da ordem de 10-6 $\mathrm{m} / \mathrm{s}$, quando compactado na energia do Proctor Intermediário. Este valor é bastante elevado quando comparado com os limites impostos pelos órgãos ambientais (10-9 m/s). Os resultados indicaram uma diminuição na condutividade hidráulica com o acréscimo de bentonita a esse solo.

Conforme previsto, a condutividade hidráulica diminui tanto com o acréscimo de bentonita quanto com o aumento dos valores das tensões de confinamento. Observou-se que o efeito da tensão de confinamento somente foi significativo quando esta foi aumentada de 0 para $100 \mathrm{kPa}$. Entretanto, para a mistura com $6 \%$ de bentonita, este efeito não se mostrou significativo. Isto ocorre, provavelmente, pelo preenchimento dos vazios que ocorre quando a bentonita é percolada pela água, o que, por sua vez, dificulta o adensamento.

No que se refere à resistência ao cisalhamento da mistura solo-bentonita, de uma forma geral, a coesão efetiva aumentou. Isto ocorreu, provavelmente, devido ao acréscimo de material fino ao solo. O ângulo de atrito efetivo do solo diminuiu. Isso provavelmente ocorreu devido a uma maior presença de material fino no solo, que age como um lubrificante. Além disso, constatou-se que o acréscimo de $6 \%$ de bentonita ao solo estudado é capaz de mudar o comportamento tensão x deformação do mesmo.

De uma forma geral, a mistura com $6 \%$ de bentonita foi a que mostrou-se tecnicamente apta a ser utilizada como barreira impermeável para o aterro sanitário do município de Rio Grande (RS). 


\subsection{Sugestões para trabalhos futuros}

Através da revisão bibliográfica apresentada fica evidente a complexidade das propriedades das misturas solo-bentonita. Desta forma, sugere-se o desenvolvimento de novas pesquisas sobre o tema:

1) Investigar os mecanismos de fissuramento em solos por meio de análises experimentais com amostras de misturas de solo-bentonita com diferentes formas geométricas e espessuras, com o intuito de verificar os efeitos destas variáveis no processo de iniciação e propagação das fissuras;

2) Avaliar o comportamento hidráulico das misturas quando percoladas por outros líquidos. Sugere-se a utilização de lixiviados provenientes de aterros sanitários ou outros fluídos contaminantes. Pretende-se assim avaliar a interação química entre a bentonita e o fluído, bem como a influência que ocorre na condutividade hidráulica;

3) Realizar ensaios para a determinação da condutividade hidráulica na direção normal ao sentido da compactação. A obtenção da condutividade hidráulica nos dois sentidos permite determinar a anisotropia do material em estudo. 


\section{Referências bibliográficas}

ALMEIDA, M.T.; BAUMGARTEN, M.G.; RODRIGUES, R.M. Identificação das possíveis fontes de contaminação das águas que margeiam a cidade de Rio Grande, RS. Documentos Técnicos. Universidade de Rio Grande, 6, 36 p. 1993.

ALONSO, T.P. Condutividade hidráulica de solos compactados em ensaios com pêrmeametro de parede flexível. 2005. 112 p. Dissertação de Mestrado, EESC-USP, São Carlos/SP.

ALSTON, C.; DANIEL, D. E.; DEVROY, D. J. Design and construction of sand-bentonite liner for effluent treatment lagoon. Marathon, Ontario. Canadian Geotechnical Journal, Ottawa, v. 34, n. 6, p. $841-852.1997$.

AMERICAN SOCIETY FOR TESTING AND MATERIALS. D 1557: D1557-12 Standard Test Methods for Laboratory Compaction Characteristics of Soil Using Modified Effort (56,000 ft-lbf/ft3 (2,700 kNm/m3)). ASTM International, West Conshohocken, USA, 28 p. 1991.

AMERICAN SOCIETY FOR TESTING AND MATERIALS. D 1973: Standard guide for design of a liner system for containment of wastes. ASTM International, West Conshohocken, USA, 13 p. 1991.

AMERICAN SOCIETY FOR TESTING AND MATERIALS. D 4767: Standard Test Method for Consolidated Undrained Triaxial Compression Test for Cohesive Soils. ASTM International, West Conshohocken, USA, 13 p. 1995.

AMERICAN SOCIETY FOR TESTING AND MATERIALS. D 4439: Standard Terminology for Geosynthetics. ASTM International, West Conshohocken, USA, 04 p. 1999.

AMERICAN SOCIETY FOR TESTING AND MATERIALS. D 5084: Standard Test Method for Measurement of Hydraulic Conductivity of Saturated Porous Materials Using a Flexible Wall Permeameter. ASTM International, West Conshohocken, USA, 23 p. 2001.

AMERICAN SOCIETY FOR TESTING AND MATERIALS. D 698: Standard Test Methods for Laboratory Compaction Characteristics of Soil Using Standard Effort (12 $400 \mathrm{ft}-\mathrm{lbf} / \mathrm{ft} 3$ (600 kNm/m3)). ASTM International, West Conshohocken, USA, 26 p. 2001. 
ANDRADE, F. S. Uso de sistemas de informação geográfica na identificação de áreas potenciais para a instalação de aterros sanitários no Distrito Federal. Dissertação de Mestrado. Instituto de Geociências da Universidade de Brasília. Brasília/DF. 1999.

ASSOCIAÇÃO BRASILEIRA DE NORMAS TÉCNICAS. NBR 7181 (MB 33): Solo - análise granulométrica. Rio de Janeiro, 13 p. 1984.

ASSOCIAÇÃO BRASILEIRA DE NORMAS TÉCNICAS. NBR 6508: Grãos de solo que passam na peneira 4,8 mm - determinação da massa específica. Rio de Janeiro, 8 p. 1984.

ASSOCIAÇÃO BRASILEIRA DE NORMAS TÉCNICAS. NBR 7182 (MB 33): Solo - ensaio de compactação. Rio de Janeiro, 10 p. 1984.

ASSOCIAÇÃO BRASILEIRA DE NORMAS TÉCNICA. NBR 7180 (MB 31): Solo - determinação do limite de plasticidade. Rio de Janeiro, 3 p. 1984.

ASSOCIAÇÃO BRASILEIRA DE NORMAS TÉCNICAS. NBR 6459 (MB 30): Solo - determinação do limite de liquidez. Rio de Janeiro, 6p. 1984.

ASSOCIAÇÃO BRASILEIRA DE NORMAS TÉCNICAS. NBR 8419: Apresentação de projetos de aterros sanitários de resíduos sólidos urbanos. Rio de Janeiro, 7 p. 1992.

ASSOCIAÇÃO BRASILEIRA DE NORMAS TÉCNICAS. NBR 10004: Resíduos sólidos - classificação. Rio de Janeiro, 2004.

ASSOCIAÇÃO BRASILEIRA DE NORMAS TÉCNICAS. NBR 12770: Solo coesivo - determinação da resistência à compressão não confinada. Rio de Janeiro, 1992.

ASSOCIAÇÃO BRASILEIRA DE NORMAS TÉCNICAS. NBR 13896: Aterros de resíduos não perigosos - critérios para projeto, implantação e operação - procedimento. Rio de Janeiro, 1997.

AZAMBUJA, R.M.B. Comportamento mecânico e hidráulico de misturas de solo-cimentobentonita para aplicação em barreiras verticais de contenção de contaminantes. 2004.98 p. Dissertação de mestrado, Universidade Federal do Rio Grande do Sul, Porto Alegre/RS.

BASTOS, C.AB; SCHMITT, L.A; VASCONCELOS, S.M; RABASSA, C.M.; SOUZA, E.W. Propriedades geotécnicas de um solo arenoso fino laterítico de barreira litorânea na Planície Costeira Sul do Rio Grande do Sul. Teoria e Prática na Engenharia Civil (online), v. 12, p. 59 - 67. 2008. 
BATISTA. P. Avaliação geotécnica de um solo laterítico com cimento e bentonita para uso em cortinas verticais. Dissertação de Mestrado. Universidade Federal de Ouro Preto. Ouro Preto/MG. 2006.

BENSON, C. H.; DANIEL, D. E. Influence of clods on hydraulic conductivity of compacted clay. Journal Geotechnical Engineering., ASCE, v. 116, n.8, p. 1231 - 1248. 1990.

BIDONE, F. R. A.; POVINELLI, J. Conceitos básicos de resíduos sólidos. Escola de Engenharia de São Carlos, Universidade de São Paulo, Projeto REENGE, 1999. 109 p.

BOUAZZA, A. Geosynthetic clay liners. Geotextiles and Geomembranes. V. 20, n.1 2002, p. 117.

BOUTWELL, G. P.; HEDGES, C. Evaluation of waste - retention liners by multivariate statistics. Proc., Twelfph In: CONF. ON. SOIL MECH. AND FOUNDATION ENGINEERING., Rio de Janeiro, Brazil, 2, p. $815-818,1989$.

BOYTON, S. S.; DANIEL, D. E. Hydraulic conductivity tests on compacted clay. Journal of Geotechnical Engineering. New York, v. 111, n. 4, p. 465 - 478. 1995.

BRANDL, H. Mineral liners for hazardous waste contaminant. Géotechnique, London, v. 42, n. 1, p. $57-65,1992$.

BRASIL. Lei N 9.605, de fevereiro de 1998, publicada no Diário Oficial da União em 13/02/98, que dispõe sobre as sanções penais e administrativas derivadas de condutas e atividades lesivas ao meio ambiente. Diário Oficial da União. Brasília - DF. 2010

BRASIL. Decreto 7404 de 23 de dezembro de 2010. Regulamenta a Lei 12.305, de 02 de agosto de 2010 que institui a Política Nacional de Resíduos Sólidos e dá outras providências. Diário Oficial da União. Brasília - DF. 2010

BUENO, B.S.; BENVENUTO, C.; VILAR, O.M. Aplicação em Barreiras Impermeabilizantes. In: Manual Brasileiro de Geossintéticos. São Paulo, Editora Edgard Bluncher, 2004, capitulo 13, p. $335-379$.

CABISTANY, T. Seis aterros podem ser construídos na região. Jornal Diário Popular. Pelotas/RS. Publicado 10 de outubro de 2009.

CAMARGO, K.R, BASTOS, C.A.B, SOUZA, E.W. Avaliação da permeabilidade de solos compactados do litoral do Rio Grande do Sul e adjacências para uso como barreiras 
impermeáveis em obras de aterros de resíduos. In: $12^{\circ}$ Congresso Brasileiro de Geologia de Engenharia e Ambiental. Porto de Galinhas/PE. 2008.

CARVALHO, M, F. Comportamento mecânico de resíduos sólidos urbanos. Tese de Doutorado. Escola de Engenharia de São Carlos. Universidade de São Paulo. 1999.

CETESB- Companhia de tecnologia e de saneamento ambiental de São Paulo. Resíduos sólidos industriais. São Paulo/SP. 1993.

CHALERMYANONT, T.; ARRYKUL, S. Compacted sand-bentonite mixtures for hydraulic containment liners. Songklanakarin j. sci. technol, v.27, n.2, p. 314-323, 2005.

CRAIG, R. F. Soil mechanics. 2004. 427p. Fifth edition. Chapman \& Hall, London.

D'APPOLONIA, D.J. Soil-bentonite slurry trench cutoff. Journal of the geotechnical engineering division, New York, v. 107, n.4, p. $393-409,1980$.

Daniel, D. E. "State-of-art: Laboratory hydraulic conductivity tests for saturated soils." Hydraulic conductivity and waste contaminant transport in soil, D. E. Daniel, and S. J. Trautwein, eds. STP 1142, West Conshohocken, Pa., 30-78. 1994

Daniel, D.E.; Benson, C.H. (1999). "Water Content density criteria for compacted soil liners." J. Geotech. Engrg., ASCE, Vol. 166. No. 12, pp. $1811-1830$.

DANIEL, D.E.; TRAUTWEIN, S.J.; BOYNTON,S.S.;FOREMAM, D.E. Permeability testing with flexiblewall permeameters. Geotechnical Testing Journal, v.7, n.3, p. $113-122$, set. 1984.

DANIEL, D.E. Clay liners. In: DANIEL, D.E. Geotechnical pratice for waste disposal. London, Chapman \& Hall, 1993, chapter 1, p. $3-14$.

DANIEL, D.E.; WU, Y.K. Compacted clay liners and covers for arid sites. Journal of Geotechnical Engineering, v. 119, n.2, p. $223-237$, fev. 1993.

DANIEL, D.E.; KOERNER, R.M. Waste containment facilities: guidance for construction, quality assurance and quality control of liner and cover system. ASCE, New York, 1995. 354 p.

DAS B.M., Principles of Geotechnical Engineering, $5^{\text {th }}$ Edition. PWS Publishing Company, USA, $2007,712 \mathrm{p}$.

DOURADO, K.A. Condutividade hidráulica de materiais de baixa permeabilidade: desenvolvimento, construção e teste de um sistema de medida. 2003. 89 p. Dissertação de Mestrado, EESC- USP, São Carlos/SP 
ENGECORPS - Corpo de Engenheiros Consultores. Rel: 064-SSO-NOD-B173. Estado da arte dos aterros sanitários - Partell, 26/04/96. São Paulo/SP, 1996, 233 p.

EMBRAPA - Empresa Brasileira de Pesquisa Agropecuária. Sistema Brasileiro de Classificação de Solos. 2 ed. Rio de Janeiro. Embrapa Solos. 2006.

EPA - U. S. ENVIRONMENTAL PROTECTION AGENCY. Code of Federal Regulations, Title 40, Chapter I, Part 264.221 - Design and operation requirements. 57 FR 3487, Jan 29, 1992. Disponível em: www.access.gpo.gov/efcr. Acesso em: 08 de novembro de 2011.

FERRARI, A.A.P. Viabilidade da utilização de silte compactado como material de impermeabilização em aterros de resíduos. 2005. Dissertação de Mestrado, Escola Politécnica da Universidade de São Paulo, São Paulo/SP.

GLEASON, N.H.; DANIEL, D.E.; EYKHOLT, G.R. Calcium and sodium bentonite for hydraulic containment applications. Journal of Geotechnical and Geoenvironmental Engineering, ASCE, New York, v. 123, n. 5, p. $438-445,1997$.

GOVERNO DO ESTADO DA BAHIA. Manual de Operações de Aterros Sanitários. 58 p. 2002.

GRAHAM, J.; SAADAT, F.; GRAY, M. N.; DIXON, D. A.; ZHANG, Q. Y. Strength and volume change behavior of a sand-bentonite mixture. Canadian Geotechnical Journal, Ottawa, v. 26, n. 2, p. $292-305,1989$.

HAN, D. Use of fly ash-residual soil mixture as a dyke material. Environmental Geotechnics. Balkema, Rotterdam, p. 721 - 726. 1996.

HEAD, K.H Manual of soil laboratory testing, Vol. 3, Effective stress tests. ELE International Limited, 1238 p., 1984.

HEINECK, K.S. Estudo do comportamento hidráulico e mecânico de materiais geotécnicos para barreiras horizontais impermeáveis. 2002. 251 p. Tese de Doutorado, Universidade Federal do Rio Grande do Sul, Porto Alegre/RS.

IBGE - Instituto Brasileiro de Geografia e Estatística - Pesquisa Nacional de Saneamento Básico (PNSB). Rio de Janeiro/RJ. 2010.

KHERA, R.P. Calcium bentonite, cement slag and fly ash as slurry wall material. In: GEOENVIRONMENT 2000 - Characterization, containment, remediation and performance in environmental geotechnics, 1995, New Orleans. Proceedings... Geotechnical special publication n. 46, ASTM, v.1, 2v, p. $1237-1249$. 
KOZICKI, P.; HARTY, S.; KOZICKI, J. P. Design and construction of soil-bentonite liners and two

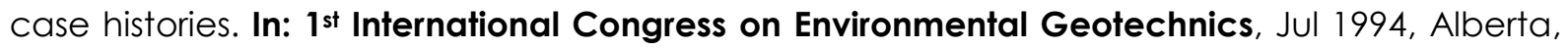
Canada. Proceedings..., 1 v., p. $713-719.1994$.

LAMBE, T.W. The structure of compactated clay. J. Soil Mech. And Found. Engrg. Div., ASCE, $84(2), 1-35.1958$.

LAMBE, T.W.; WHITMAN, R.V. Soil mechanics, SI version. NeW York, John Wiley and Sons Inc. 553 p. 1969.

LEITE, J.C. Prevenção da contaminação e polvição de aquíferos: a utilização de liners. Boletim de Geociências, São Paulo, V.14 (1), p. 167 - 178, 1995.

LIMA, L.M.Q. Tratamento de lixo. São Paulo: Hermus Editora Ltda., 1985. 240 p.

LUKIANTCHUKI, J.A. Influência do teor de bentonita na condutividade hidráulica e na resistência ao cisalhamento de um solo arenoso utilizado como barreira impermeabilizante. Dissertação de Mestrado. Escola de Engenharia de São Carlos. 2007.

MACAMBIRA, I.Q. Comportamento hidráulico de alguns solos lateríticos para uso como barreira impermeável. 2002. 117 p. Dissertação de Mestrado, EESC - USP, São Carlos/SP

MCBEAN, E.A; ROVERS, F.A; FARQUHARS, G.J. Solid waste landfill engineering and design. Prentice Hall PTR, USA. 1995.

MESRI, G.; OLSON, R.E. Mechanisms controlling the permeability of clays. Clays and clays minerals, v. 19, 1971.

MITCHELL, J.K.; HOOPER, D.R.; CAMPANELLA, R.G. Permeability of compacted clay. Journal soil mechanics and foundations div., ASCE, 91 (SM4), p. $41-65,1965$.

MITCHELL, J.K. Fundamentals of soil behavior. $2^{a}$ edição. Berkeley: John Wiley \& Sons, 1993. $437 \mathrm{p}$.

MUNDELL, J.A; BAILEY, B. The design and testing of a compacted clay barrier layer to limit percolation. 1985.

NOGAMI, J.S., VILLIBOR, D.F. Pavimentação de baixo custo com solos lateríticos. Ed. Villibor, São Paulo, 212 p., 1995.

NOGUEIRA, J.B. Mecânica dos solos - ensaios de laboratório. São Carlos: Serviços gráficos EESC - USP), 2005. 248 P. 
Olsen, H. 1962. Hydraulic flow through saturated clays. Clays \& Clay Miner. 11: 131-161.

OLSON, R.E.; DANIEL, D.E. Measurement of the hydraulic conductivity of fine-grained soils, permeability and groundwater contaminant transporte. ASTM STP 746, T.F. Zimme and C.O. Riggs, Eds., American society for testing and materials, Philadelphia, pp. 18 - 64. 1981.

PEJON, O.J. Mapeamento geotécnico da folha de Piracicaba (escala 1: 100.000): Estudo de aspectos metodológicos, de caracterização e de apresentação dos atributos. 1992. 213 p. Vol.1. Tese de Doutorado, EESC-USP, São Carlos/SP.

QUERIO, A.J.; LUNDELL, C.M. Geosynthetic use as daily cover. Geotextiles e Geomembranes, V.11, p. $621-627.1992$.

PINTO, C.S. Curso básico de mecânica dos solos. São Paulo, Oficina de textos, 2000. 247 p.

Plano estadual de recursos hídricos: primeiro plano do estado de São Paulo. São Paulo, 1990. $97 p$.

ROWE, R.K. Barrier Systems. In: Geotechnical and geoenvironmental engineering handbook. Ontario, Kluwer academic publishers, 2000, chapter 25, p. $739-788$

SANTOS, P.S. Ciência e tecnologia de argilas. $2^{a}$ edição. São Paulo: Editora Edgar Blucher Ltda, 1989. 408 p.

SEDU - Manual de gerenciamento integrado de resíduos sólidos. Disponível em http://www.resol.com.br/cartilha4/apresentacao/apresentacao.asp. Acesso em 14 nov. 2011.

SHARMA, H.D.; LEWIS, S.P. Waste containment system, waste stabilization, and landfills, desing and evaluation. Wisley Interscience Publication, p.588, 1994.

SILVA, C.F. Estudo sobre a influência do teor de bentonita na condutividade hidráulica e nas propriedades índices e mecânicas de solo arenoso fino laterítico para emprego em barreiras minerais. Trabalho de Conclusão de Curso. Universidade Federal do Rio Grande. Rio Grande/RS. 2011.

SILVA, C.F, CAMARGO, K.R., BASTOS, C.A.B. Determinação de características geotécnicas de solo arenoso fino costeiro-bentonita para uso como barreira mineral. VI Seminário de Engenharia Geotécnica do Rio Grande do Sul. Passo Fundo - RS. 2011. 
SOUZA, E.W. Estudo do emprego de misturas solo-bentonita na construção de liners para a impermeabilização de aterros sanitários - Estudo de caso: aterro sanitário de Rio Grande/RS. 162 p. Projeto de Graduação (Engenharia Civil), FURG. 2007.

TIVERON, V.P.M.; MARQUES, A.C.M.; NAHAS, C.M; FRAÇOSO, N.C.T.; GODOI, M.O. Disposição de resíduos sólidos no município de São Paulo: aterros sanitários. I Seminário Luso-Brasileiro de Geotecnia Ambiental, Lisboa, 15 p., 1995.

VILAR, O.M. Mecânica dos solos - apostila de resistência ao cisalhamento. São Carlos: EESC/ USP).196 P. 2005.

VILLWOCK, J.A. Geology of coastal province of Rio Grande do Sul, Southern Brazil. A Synthesis. Pesquisas, 16:5-49. 1984.

VILLWOCK, J.A. \& TOMAZELLI, L.J. Geologia costeira do Rio Grande do Sul. Notas Técnicas do CEGO-IG-UFRGS. Porto Alegre/RS, 8: 1-45. 1995.

YAN REE, C. C. D.; WESTSTRATE, F. A.; MESKERS, C. G.; BREMMER, C. N. Design aspects and permeability testing of natural clay and sand-bentonite liners. Géotechnique, London, v. 42, n. 1, p. $49-56,1992$.

ZUQUETTE, L.V., PEJON, O.J. Importância dos estudos geológico-geotécnicos para a disposição de rejeitos urbanos. In: II Simpósio sobre Barragens de Rejeitos e Disposição de Resíduos - REGEO'91. Anais. Rio de Janeiro/RJ. Anais. p. 367 - 377. 1991. 
